University of Louisville

ThinkIR: The University of Louisville's Institutional Repository

Electronic Theses and Dissertations

1939

\title{
A classroom illumination study of the public school system of Jeffersonville, Indiana.
}

Ross Graham

University of Louisville

Follow this and additional works at: https://ir.library.louisville.edu/etd

Part of the Education Commons

\section{Recommended Citation}

Graham, Ross, "A classroom illumination study of the public school system of Jeffersonville, Indiana." (1939). Electronic Theses and Dissertations. Paper 1804.

https://doi.org/10.18297/etd/1804

This Master's Thesis is brought to you for free and open access by ThinkIR: The University of Louisville's Institutional Repository. It has been accepted for inclusion in Electronic Theses and Dissertations by an authorized administrator of ThinkIR: The University of Louisville's Institutional Repository. This title appears here courtesy of the author, who has retained all other copyrights. For more information, please contact thinkir@louisville.edu. 
UNIVERSTTY OF LOUISVILIE

A CIASSROOM ILLTMINATION STUDY

$$
\text { OF }
$$

THE PUBLIC SCHOOL SYSTEM

$\mathrm{OF}$

JEFFER SO NVILLE, IND IANA

\author{
A Dissertation \\ Submit ted to the Faculty \\ Of the Graduate School of the University of Louisville \\ In Partial Fulfillment of the \\ Requirements for the Degree \\ of Master of Arts
}

Department of Education

By

Ross Graham

June, 1939 
Name :

Title: A CLASSROOM ILIUMTNATION STUDY $\mathrm{OF}$

THE PUBLIC SCHOOL SYSTEM OF JEFFER SONVILLE , INDIANA

Director :

Approved by 9 reding committee composed of the following members:

Representative of the English Department:

Date:

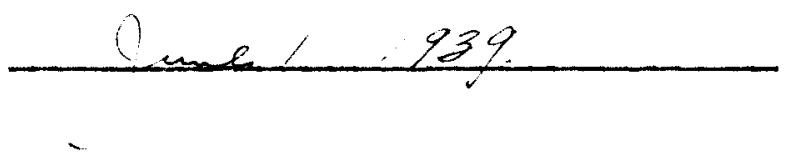


TABLE OF CONTENTS

CHAPTER

PA GE

I. THE PROBLEM AND DEFINITIONS OF TERMS USED..... 1

The problem........................ 2

Definitions of terms used.............. 4

II. PHOTONETRICS USED IN THE SURVEY.......... 8

Instruments...................... 9

III. DIGEST OF PERTINENT LITERATURE........... 22

IV. SOURCES AND TREATMENT OF DATA...........4 42

V. STATISTICAL AND GRAPHICAL ANALYSIS OF FINDINGS 51

VI. CONCLUSIONS AND RECOMNENDATIONS.......... 82

Conclusions......................... 83

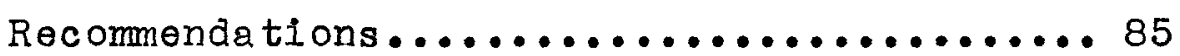

BIBLIOGRA PHY ........................... 89

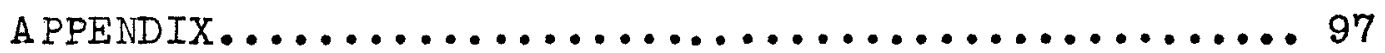


IIST OF TABLES

TABLE

PAGE

A. Statistical Data for Illumination Curves

I. Spring H111 Elementary School.......... 57

II. Chestnut street Elementary School......... 60

III. Rose Hill Elementary School.............. 63

IV. Port Fulton Elementary School........... 66

V. Ingramvilie Elementary School............ 69

VI. Taylor Colored School................. 72

VII. Junior High School.................. 75

VIII. Senior High School.................. 78

B. Statistical Analysis of Data

IX. Spring Hill: Bright Days.............. 58

X. Spring HIII: DuIl Days................. 59

XI. Chestnut street: Bright Days............. 61

XII. Chestnut street: DuII Days.............. 62

XIII. Rose Hill: Bright Days................... 64

XIV. Rose Hill: Dull Days.................65

XV. Port FuIton: Bright Days................ 67

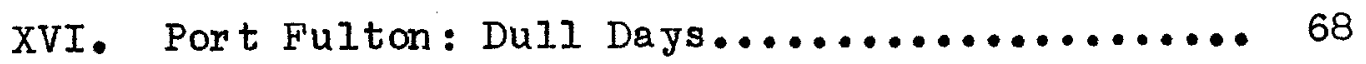

XVII. Ingramville: Bright Days.............. 70

XVIII. Ingramvil1e: DuII Days................ 71

XIX. Taylor Colored: Bright Days.............. 73

XX. Taylor Colored: Dull Days................ 74 
TA BLE

PAGE

XXI. Junior High School: Bright Days.......... 76

XXII. Junior High School: Dull Days............ 77

XXIII. Senior High School: Bright Days........... 79

XXIV. Senior High School: Dull Days............ 80

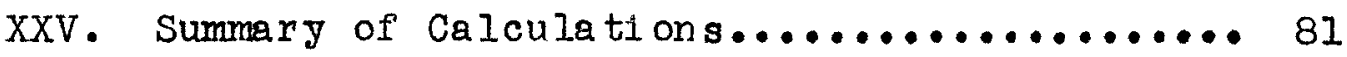


IIST OF FIGURES

FIGURE

PAGE

1. Weston Foot-candle Meter................... 15

2. Intercepting Screens and Masks............... 15

3. Light Meter and Additional Photo-Electric Cells.. 17

4. Special Fóot-candle Meter.................. 17

5. Schemat1c Wiring Diagram of Special Light Meter.. 18

6. Unassembled Parts for Special Meter............ 21

7. Common Experiences in Light and Vision.......... 21

8. Societies Approving Adoption of I. E. S. Code.... 30

9. Recommended Code of School Lighting........... 30

10. Physiological Reactions Under Different

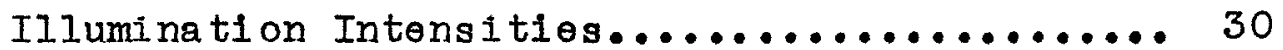

11. Time and Light Required for Discrimination...... 36

12. Time and Light Required for Perception........ 36

13. Time and Light Required for Reading........... 36

22. Illumination Survey Record Form.............. 50

44. Form Sheet for Collection of Physical Data...... 111

45. Characteristics of Photronic Cells............. 112

PHOTOGRAPHS OF BUILDINGS SURVEYED

14. Spring Hill........................... 47

15. Chestnut Street......................... 47

16. $\operatorname{Ros} \theta \mathrm{H} 111 \ldots \ldots \ldots \ldots \ldots \ldots \ldots \ldots \ldots \ldots \ldots \ldots \ldots \ldots \ldots . \ldots . \ldots . \ldots$

17. Port Fulton........................... 48 
18. Ingramville......................... 48

19. Taylor Colored.......................... 48

20. Junior High School...................... 49

21. Senior High School....................... 49

ILLUMINA TION IEVEL DISTRIBUTION GRAPHS

23. Spring $H i l 1 \ldots \ldots \ldots \ldots \ldots \ldots \ldots \ldots \ldots \ldots \ldots \ldots \ldots \ldots \ldots \ldots$

24. Chestnut street......................... 60

25. Rose Hill........................... 63

26. Port Fulton........................... 66

27. Ingramvil le........................... 69

28. Taylor Colored.......................... 72

29. Junior Hign School..................... 75

30. Senior Hign Scnool..................... 78

FLOOR PIANS OF BUIIDINGS SURVEYED

31. Spring Hill: Second Floor................ 98

32. Chestnut street: First Floor............... 99

33. Chestnut street: Second Floor.....................

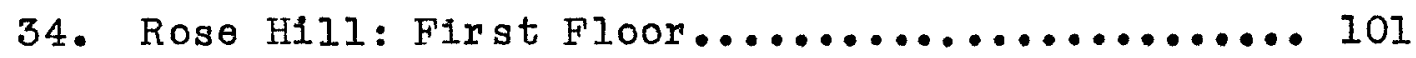

35. Rose Hill: Second Floor.................. 102

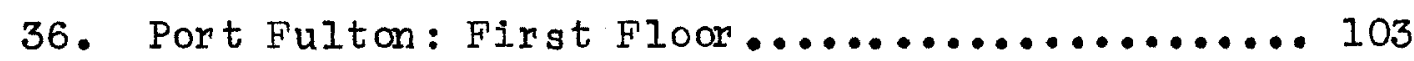

37. Port Fulton: Second Floor.............................

38. Ingramville: First Floor................ 105

39. Teylór Colored: Fir st Floor................ 106 
40. Taylor Colored: Second Floor............... 107 41. Junior Hign School: First and Second Floors... 108 42. Senior High School: First Floor............. 109 43. Senior High School: Second Floor............. 110 


\section{ACKN OWLEDGMENTS}

For permission to conduct this survey, the writer is grateful to Mr. E. G. McCullum of the Jeffersonville public school administration staff. The aid offered by the research laboratories of Weston Electrical Instrument Corporation and the General Electric Company is deeply appreciated. Special tnanks are due to the Illuminating Engineering Society and the General Electric Company for the permission to reproduce some of their copyrignted material.

To all other persons who have helped in the preparation of this thesis, especially to those who contributed to the collection of the original data, the author is directly indebted.

$$
\text { R. G• }
$$


CHA PTER I

THE PROBLEM AND DEFINITION OF TERMS USED 
THE PROBLEM AND DEFINITIONS OF TERMS USED

Purpose. The purpose of this investigation is (I) to obtain, digest, and analyze the data relative to representative classroom illumination in the public school system of Jeffersonville, Indiana; (2) to present statistical and graphical analyses of these findings; and (3) to compare the results wi th standard norms.

Validation. The importance of any step in the direction of discovery and correction of illumination Inadequacy can be appreciated only when viewed from the perspective of its concomitant results. There is evidence to support the belief that improper light can (I) influence scholarship; (2) cause nearsightedness and other refractive defects of vision; (3) alter dispositions; and (4) produce drowsiness, indigestion, and neadaches. ${ }^{1}$

A procedure that contributes towards the elimination of any of these undesirable conditions should be considered important. On the basis that discovery of faults must precede correction, this investigation becomes fundamentally wor th-while.

1 Cf. post. pp. 27 et. sqq. 
Delimitations. The scope of this study is restricted to classroom 1llumination as it actually existed. No attempt was made to improve the conditions encountered before the raw data was collected.

Furthermore, the conclusions and deductions from this inquiry apply exclusively to the specimen rooms. No comparison to rooms not examined is intended. 


\section{DEFINITION OF TERMS}

The field of illuminating engineering contains many terms that are completely confusing to the uninitiated. In the literature of the physics of light alone, efficiency in description has demanded the frequent use of specialized vocabulary, technical terminology, and scientific definitions. Many common words that are used rather loosely in ordinary conversation have connotations that are definitely peculiar to tnis branch of science. To clarify and integrate this lack of verbal articulation, the following important definitions and explanations are offered.

International candle. For several generations the common artificial illumination was provided by candles. These were of ten home-made, and therefore not standardized In their ability to produce light. When new light sources began to supersede the candle, it was most natural that the illuminating power of these new luminants should be expressed in terms of the candle familiar to all. The standard international candle, as finally àgreed upon, was a sperm candle seven-eighths of an inch in diameter and burning at the rate of 120 grains per hour. ${ }^{1}$ Such a

I R. A. Millikan, and H. G. Gale, New Elementary Physics, (Boston: Ginn and Company, 1936), $\overline{p_{\bullet}} 449$. 
source is said to emit light at the rate of one candle power. Hence, it is readily seen that the international candle is an arbitrary unit for measuring luminous intensity.

Foot-candle. While the intensity of any light source is measured in terms of candle power, the intensity of illumination is usually measured in foot-candles. Intensity of a source is a cause, and intensity of illumination the effect or result. Thus, to measure the illumination on a newspaper, book, desk, or otner working plane, the unit called a foot-candle would be used.

A foot-candle represents the amount of illumination equal to that produced at a point on a plane one foot distant from a source of one candle power. ${ }^{1}$ since Kepler's law of the propagation of light states that the intensity of illumination of a surface varles inversely as the square of the distance of the surface from the source of light, the foot-candles of illumination for any given condition are determined by the mathematical formula; ${ }^{2}$ foot-candles $=\frac{\text { candle power }}{\text { feet }}{ }^{2}$ For example, a source of thirty-two candles at a distance of four

1 Ibid. pp. 493-494.

2 Ward Harrison and K. A. Staley, Fundamentals of Illumination (Cleveland, Ohio: General Electric Research Department, 1931), pp. 1l-12. 
feet from a plane would illuminate that surface with two foot-candles. This law a ssumes that the surface is perpendicular to the incident rays of light. In other cases of oblique lighting the foot-candies vary directly as the cosine of the angle of incidence. ${ }^{I}$

Reflection--Factor and Brightness. Although two objects may receive the identical number of foot-candies of 1llumination, one may not ap pear as bright as the other. This phenomenon is explained by the fact that the two objects absorb different amounts of light. The eye sees them only by the reflected light. The percentage of light reflected by a surface determines its reflection-factor. If an object reflects all of the light that falls upon it, its reflection-factor is taken at unity. Any amount of reflection less than perfect reflection is. so designated by decimal fractions of unity indicating the degree of reflection. 2 White blotting perer, which has a reflection factor of .8 , would, therefor $\theta$, reflect eighty per cent of the light that fell upon it. Likewise, so-called black cloth with a reflection factor of .05 reflects only five

1 Ibid. p. 10.

2 M. Luckiesh, Seeing, (Baltimore, The Williams and Wilkins Company, 193i) pp. 57-60. 
per cent of its illumination. Therefore, brightness is determined both by the number of foot-candies of illumination and by the reflection-factor inherent in the material itself.

Contrast. This term may be defined as the difference in brightness between an object and its background. The mathematical formula for this relation is as follows: ${ }^{1}$ Per cent contrast Background brigntness-object brightness

Background brightness

Glare. Any brigntness within the field of vision of such a character as to cause annoyance, discomfort, interference with vision, or eye fatigue is called glare.2 Just as dirt has sometimes been defined as matter out of place, so may glare be defined as light out of place; that is, it may come directly from the light source to the eye, or it may be reflected brightness such as that from a desk top, polished machine parts, or glazed paper. The extent to which glare is objectionable is partially dependent upon the contrast in brightness between the light source and the background. Automobile headlights on an unlighted highway, for instance, may be so glaring as to be blinding to the

1 Ibid. p. 46.

2 Harrison, op. c1t., pp. 40-4I. 
eye: the same lights in the daytime or on a well lighted street would scarcely be noticed. The presence of glare is probably one of the most common and serious faults of lighting.

Photometers. Meters designed to measure quantitatively the amount of 1llumination in foot-candies are called photometers. A detailed description of the types used in this survey is given in the following chapter. 
CHA PTER II

PHOTOMETRICS USED IN THE SURVEY 


\section{PHOTOMETRICS USED IN THE SURVEY}

\section{Instruments}

The early types of photometers used for measuring foot-candles of illumination were entirely unsuitable for an extensive survey of light conditions in which many variables were existent. These instruments were handicapped by bulk, weight, and length of time necessary for a single reading. Although they were quite accurate for laboratory experiments verifying the fundamental laws of light propagation, these instruments were definitely inadequate for field work.

Direct reading photometers of the portable type made their appearance practically simultaneously with the comparatively recent invention of the photo-electric cell, sometimes referred to as the "electric eyo."

The Weston Electric Instrument Corporation of Newark, New Jersey, manufactures one of the accepted standard photometers of the electric cell type. This apparatus consists of a Photronic cell of the photo-emissive classification coupled electrically to a very sengitive galvanometer. The galvanometer is graduated directly in foot-candies. The design of the electric eye is such that 1.4 micro-amperes of current represents one foot-candle of 1llumination. 
Most of the commercial light and power companies use this instrument which is known as the model \#703 Weston Light Meter.

Altnough the device just described was used as the basic instrument for this survey, it possessed certain limitations which necessitated the use of special auxiliary accessories and the design of a photometer which was more flexible and versatile for the purposes of this study than the regular model \#703.

The standard Weston meter has a calibrated range from 0 to 50 foot-candles. A $r a n g e$ of this limit is quite satisfactory for most indoor determinations when the 1llumination is supplied by artificial means. However, an understanding of the wide variations of illumination intensity levels encountered in any survey of this sort is essential to an appreciation of the necessity for apparata of diverse ranges. As mentioned in more detail elsewnere in this treatise, the amount of light supplied outdoors by bright sunshine often attains values as high as ten thousand foot-candles. Under the snade of a tree or porch on such a day, the value is in the neighbornood of one thousand to three thousand foot-candles. Indoors this value drops so rapidly it is almost beyond human conception to realize that, even under good conditions, 
natural daylighting often falls as low as twelve or fifteon units. Although most illuminating engineers strive to obtain as much intensity as possible, commensurate with cost under artificial illumination, yet this value rarely exceeds ten foot-candles even in library reading rooms. Hence, in consideration of these facts, it is easily seen that for a complete collection of data pertinent to the subject, meters are necessary that can accurately determine values between the extreme limits of zero and several hundred light units.

In order to extend the range of the basic meter \#703, metallic masks were machined to precision tolerances. These masks intercepted the light on a predetermined portion of the sensitized area and thus made it possible within cortain limits to use an integral conversion factor as a multiplier of the meter readings throughout the entire scale. The first mask was made after determining by micrometer measurement the diameter of the sensitized surface of the light cell. This dimension must not be assumed to be that of the glass cover, since the cell is active only to the phosphor bronze contact ring. The diameter to tnis ring measures 1.483 inches. By multiplying tnis constant by .707 a diameter of 1.048 inches was obtained. The internal diameter of the mask was machined to tnis size. Since tnis 
opening admitted light to only one-half of the active area, the range of the meter was exactly doubled throughout the entire scale.

Similarly, by making the next mask with a circular opening of .7415 inches diameter, its factor of conversion became four, thereby increasing the range of the meter to a maximum reading of 200 foot-candles. It will be noticed from the diagrams and photographs that the metal thickness was beveled to a knife edge at the inner opening, in order to prevent tiny shadows at this point from introducing an uncontrollable deviation in readings.

Although these two masks, which respectively doubled and quadrupled the range of the light meter, were found to be valuable accessories, other masks which were designed to multiply the readings of the instrument by ten or more were found quite unsatisfactory. Any interception of this nature which obstructed more than 75 per cent of the active area of the Photronic cell was found to be very irregular in its multiplying factor. For rays of light normal to the plane of the meter, a constant multiplier could be used with accuracy, but when these rays became markedly oblique to the surface no prediction could be made as to the proper multiplier to use.

Other forms of partial interception in the nature of 
filters were considered, but rejected, because of the fact that filters not only reduce the intensity of light, but rob the lignt of some of its spectral quality. Colored filters of gelatin film, cellophane, and glass were discarded on account of this fact. The only acceptable interceptors of this nature were found to be ground glass, opal glass, and the quite expensive Polaroid discs recently placed on the open market. By developing a photographic negative to a uniform density, an additional substitute was investigated and found quite satjsfactory except for the difficulty in nandling. A lack of durability, together with a definite susceptibility to scratches and finger prints made this photographic emulsion poorly adapted to repeated usage.

To supplement the basic instrument and its accessories, a special auxiliary photometer was assembled according to the following description. The foundation of this special meter was composed of two electric eyes instead of just one. Two standard Pnotronic units were mounted flush in a onesixteenth inch thick aluminum panel which also carried a Jewell micro-ammeter of high sensitivity and an accuracy of less than two per cent error. "Pattern number 51 " commercially identifies this indicating device. The particular scale and range of the meter selected were respectively, "center scale zero," and 500 micro-amperes in eitner direction. 


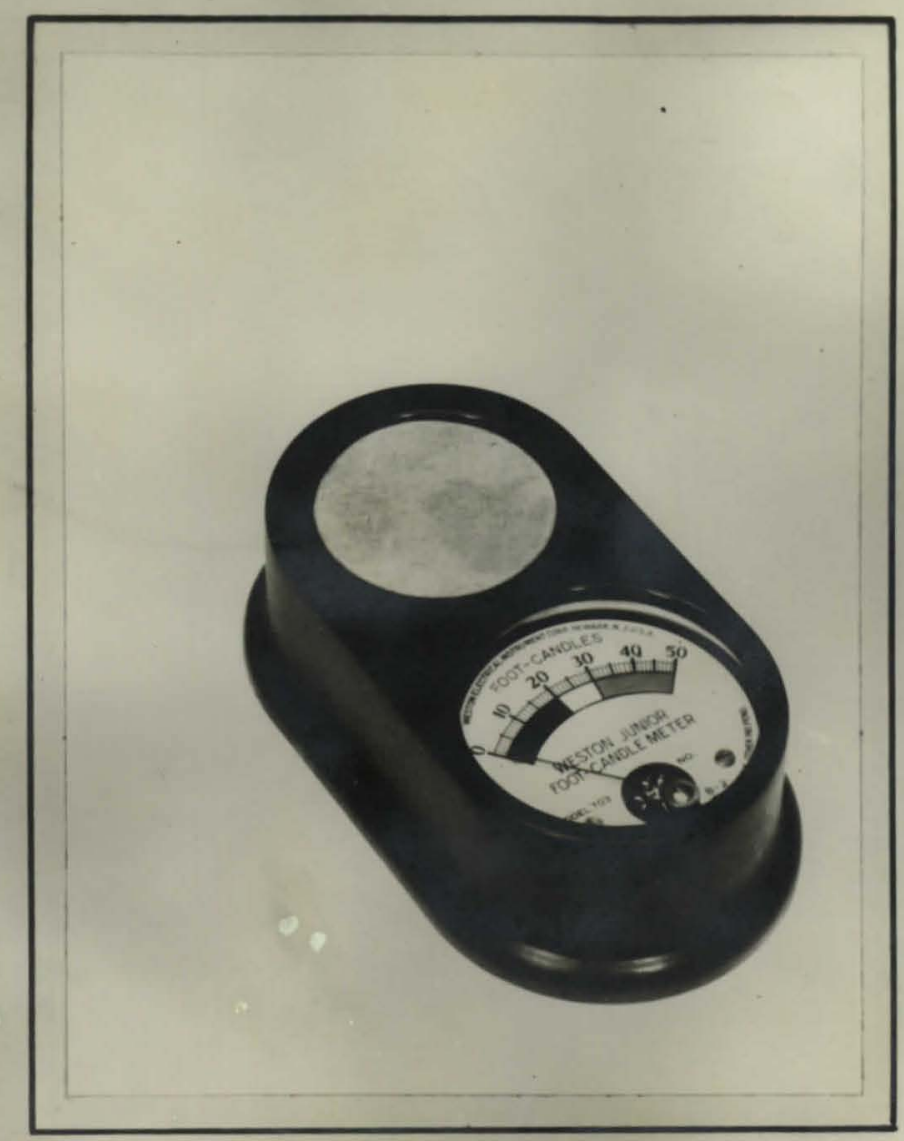

FIGURE 1

WESTON FOOT-CANDLE METER

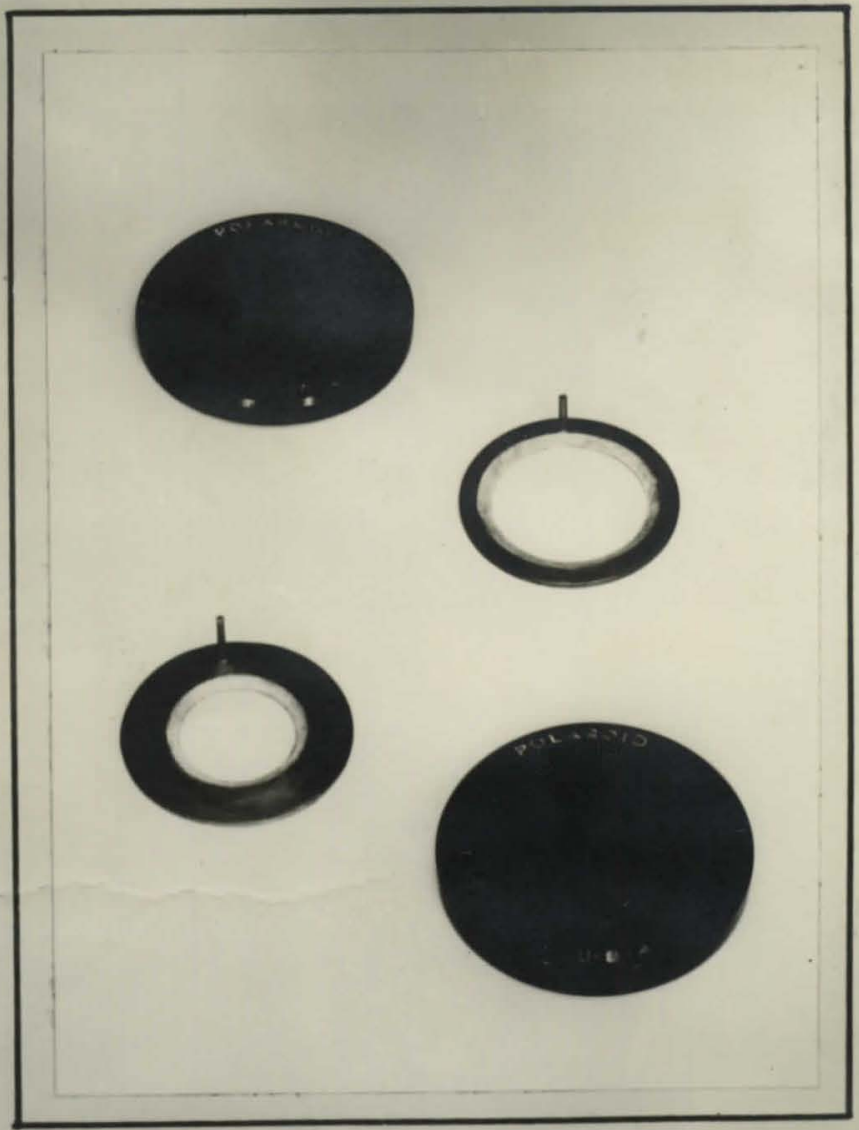

FIGURE 2

INTERCEPTING SCREENS AND MASKS 
The panel was shaped closely to the outline of the assembled units and tnen placed in a conforming wood supporting base. Two toggle switches were included, one mounted in the top and the other on the side of the instrument. A standard 500 onm resistance placed within the nousing completed the construction. The wiring diagram, Figure 5, describes the electrical circuits possible. It will be readily seen by tracing the sketch and at the same time considering the laws of mathematical combinations when using the two different intercepting masks previously described, that a total of fourteen different arrangements is possible. These are obtained by proper switching of circuits in conjunction with the use of the proper masks. The combinations that are most important and easiest to use are indicated in the following classification:

1. One Photronic cell connected direct to meter.

2. Two cells connected directly in parallel to meter.

3. One cell connected to meter through the 500 onm series resistance.

4. Two cells connected in multiple and the pair connected in series to the meter and resistance.

5. The metallic masks applied to any of tne above situations, singly or in combination with each other. 


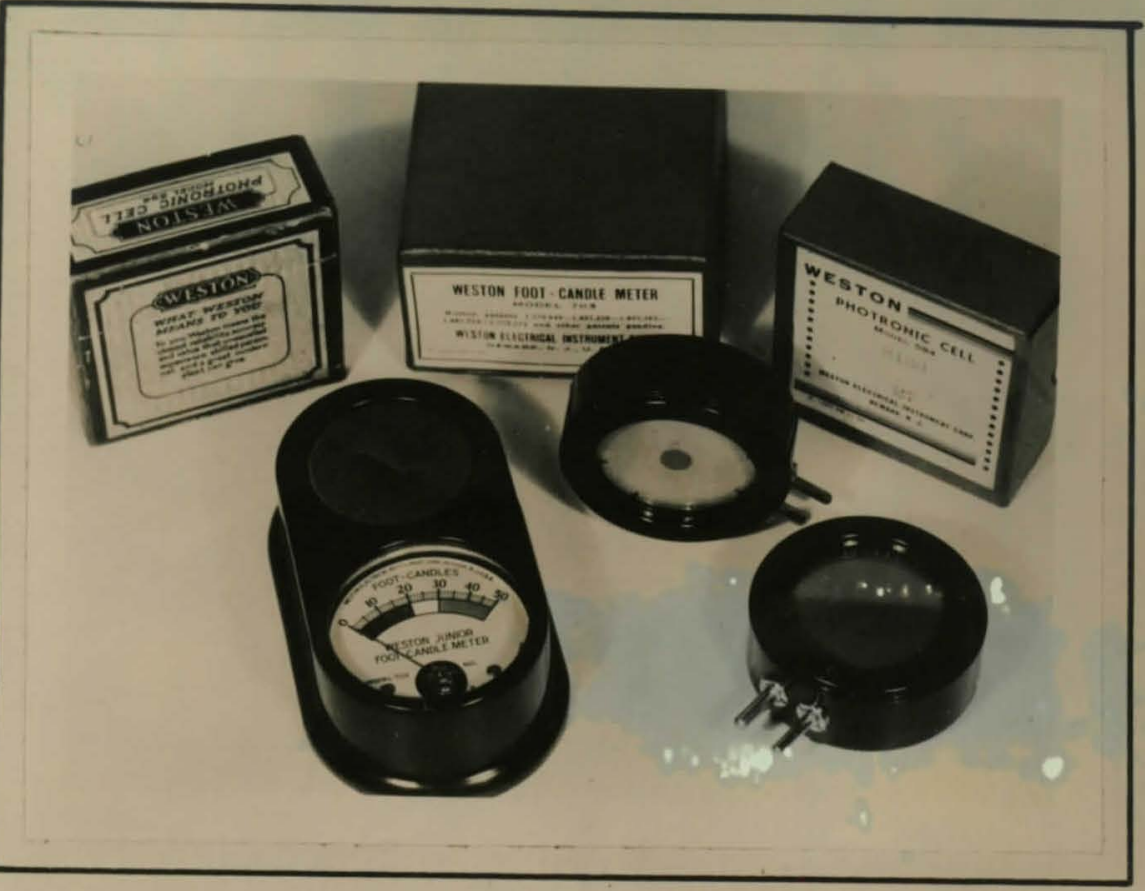

FIGURE 3

LIGHT METER AND ADDITIONAL PHOTO-ELECTRIC CELLS

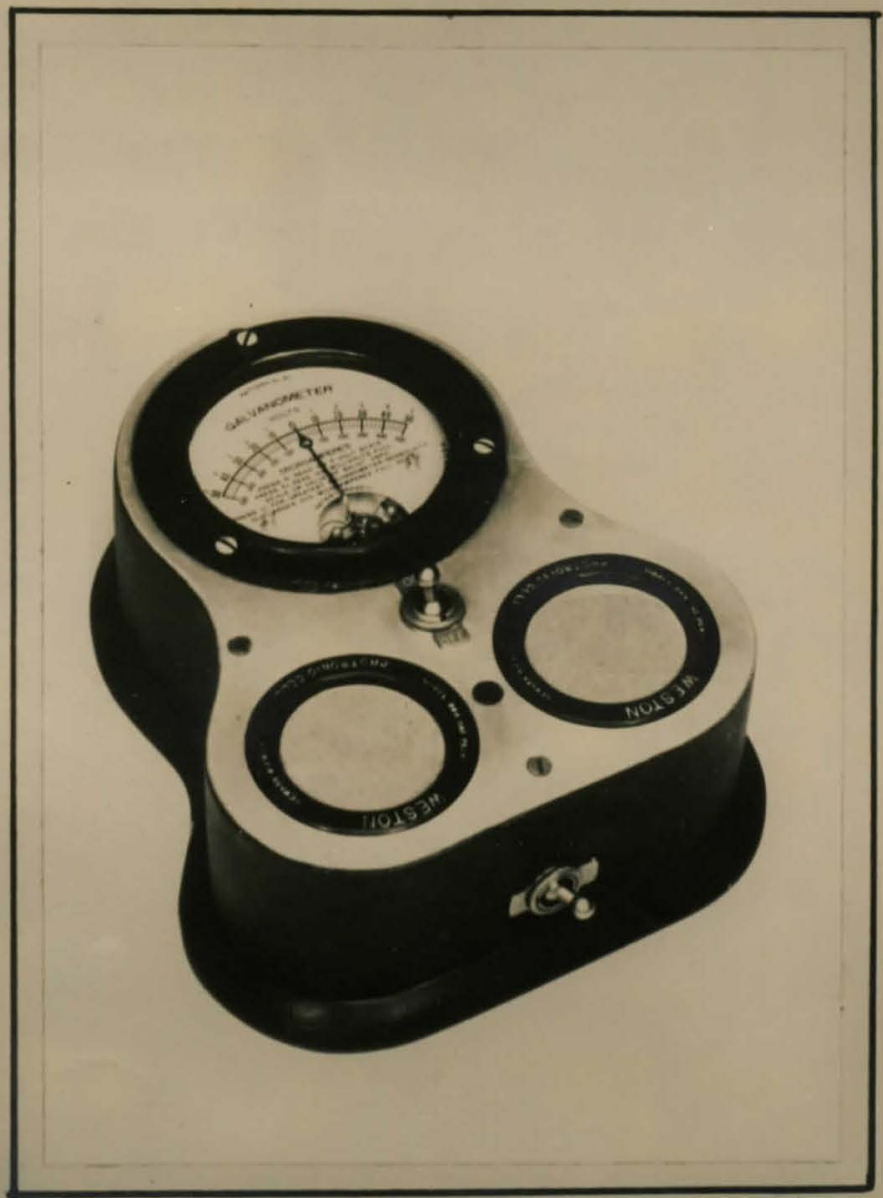

FIGURE 4

SPECIAL FOOT-CANDLE METER 


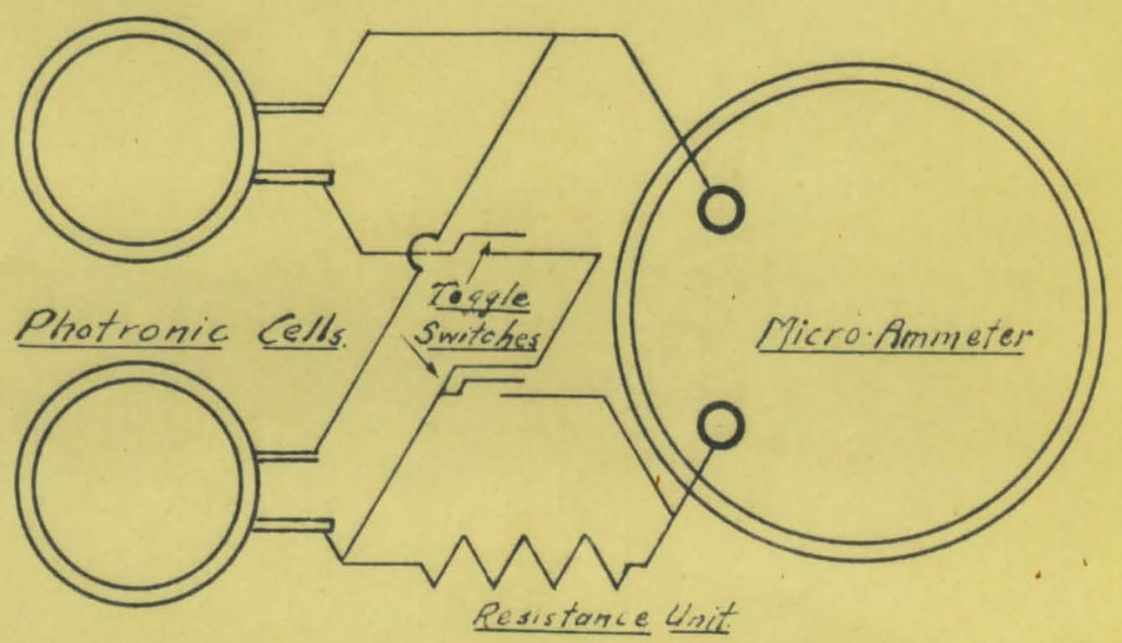

Fig. 5. Schematic Wiring Diagram speciol Light Meter 
The cholce offered by these widely divergent arrangements made possible, as the condition demanded, the reading of extremely low light values or extremely high intengities.

The calibration of the instrument in any case was accomplished by considering the amount of exposed sensitive cell area connected to the micro-anmeter. To convert these current readings into foot-candles, it was necessary to prepare a table of conversion factors which were obtained from the menufacturers' specifications for these cells. These constants are contained in the graphs shown in Figure 45, on pagell2 of the appendix.

To guarantee a reasonable degree of accuracy, both instruments were tested separately on an optical bench with both a standard sixteen candle-power and a thirty candlepower light at varying distances. The meters were checked against each other, and als o compared to the values mathematically determined by measurement on the optical bench. As a still further check, they were compared in a given situation to the readings of the meters used by the Indiana Northern Power and Light Company as well as those used by the Indiana Public Service Company. In all cases, the accuracy was found to be well within the limit of human observational error. 
Although the above equipment functioned quite satisfactorily under all conditions encountered, the only serious objection was found in the total cost. The special meter, witn its two electric eyes at ten dollars each, plus the micro-ammeter at fifteen dollars, ran the price for these three major perts al one to thirty-five dollars. The basic foot-candle meter was listed at nineteen and a nalf dollars. To these costs must be added incidental outlays for switches, metal, and labor costs for macnine tool operations upon the various parts of the construction. 


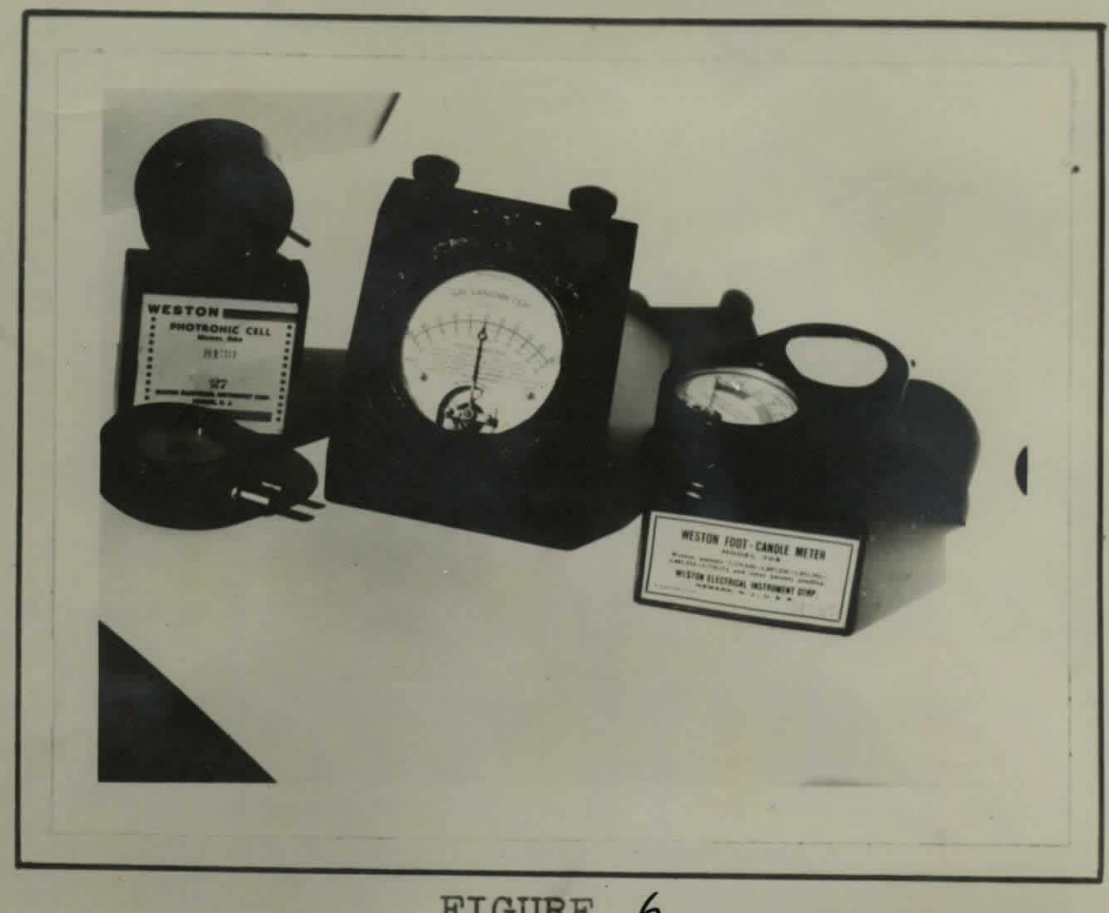

FIGURE 6

UNASSEMBLED PARTS FOR SPECIAL METER

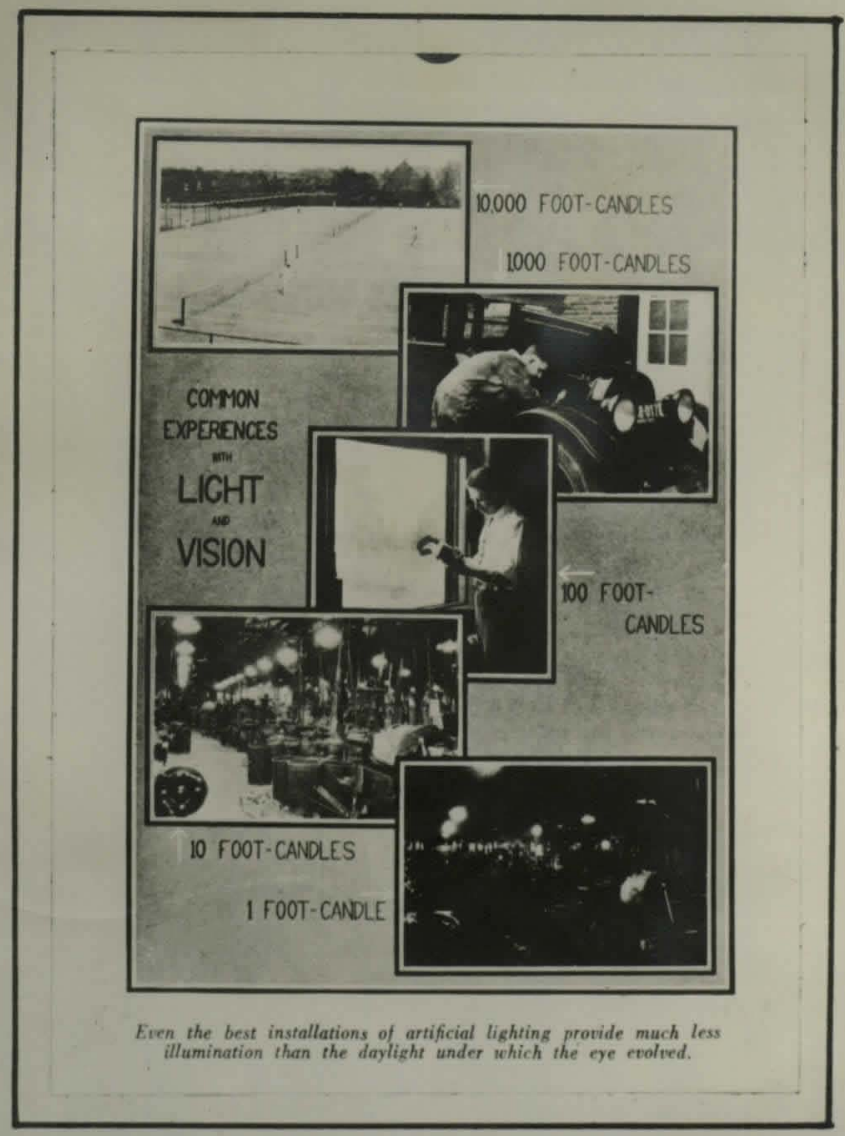

FIGURE 7

COMPARISONS OF ILLUMINATION LEVELS UNDER DIFFERENT CONDITIONS 


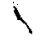

CHA PTER III

DIGEST OF PERTINENT LITERATURE 


\section{DIGEST OF PERTINENT LITERATURE}

The results of any illumination survey can be viewed critically only with knowledge of the major studies in the realm of vision. The outstanding researches in this field have been promoted and financed, for the post part, by private corporations and professional societies. Pernaps the most prolific contributions have originated in organizations sponsored by General Electric Company, Westinghouse Corporation, Illuminating Engineering Society, or the American Institute of Arcnitects. Apparently the individual most frequently quoted in periodical literature, as well as the author of the greatest number of textbooks on the subject is Matthew Luckiesh, the Director of Research of the General Electric Lighting Laborator $\mathrm{J}$.

The complexity of the problems involved in indoor illumination has for its foundation the history of the development of the human eje. Until comparatively recent generations, man was for centuries distinctly an outdoor animal. Through the prenistoric period to the modern period, this type of life evolved the sense of sight that was best adapted for functioning in sunlight. Only after present-day conditions had brought man indoors, did widespread vision difficulties arise. Two factors are 
responsible for the increased demand upon vision brought about by this transition. One was the greatly reduced amount of illumination and the other was the greater seriousness and more detailed minuteness of the tasks constituting the indoor work. In tnis connection, Hillyer states that the present generation use their eyes thirty per cent more than the last generation. ${ }^{1}$

Differences between outdoor and indoor illumination on the same day are a lmost unbelievable. In bright sunshine the intensity of illumination of ten attains values as high as ten-thousand foot-candles. Even in the shade, values range from one-thousand to three-thousand light units. When daylight outdoors becomes as low as five-hundred, it is a very dull and dark day, indeed. On the other hand, there are few buildings in which the level of illumination reaches more than ten foot-candles, except at locations near the windows. 2 In many rooms, points removed from the windows by more than twenty feet have less than three foot-candles. At first thought, this disparity seems impossible. However, if one has ever attempted to take a pnotograph indoors, either

1 E. Hillyer, "Good Light Saves Wear and Tear on Eyes, Nerves, and Dispositions," Delineator, 130:4, February 1937.

$2 \mathrm{M}$. Luckiesh, Ilght and Work, (New York: D. Van Nostrand Company, 1924T pp. $52-5 \overline{3}$. 
he has realized the light difference, or he has experienced failure. For example, on a clear day outside, a lens setting of fl6 at one-fiftietn of a second will ordinarily produce a normal negative. However, an indoor exposure to procure the same negative density will require an approximate setting of $\mathbf{f 3 . 5}$ at one second. Dividing one exposure by the other produces the ratio of 1600 to 1 . This figure agrees favorably witn the corresponding light values given above. An interpretation of this ratio means that the illumination level outdoors was 1600 times as great as that indoors.

In regard to the nature of indoor work, it is common knowledge tnat clerlcal, professional, and skillful activities are much more exacting than those performed outside. In fact, a study by Luckiesh shows that defects in vision are not nearly so common among farmers, policemen, and other outdoor workers as among machinists, moulders and factory laborers. 1

Cobb states that twenty per cent of the grade school population have impaired vision. 2 This figure advanced to

I M. Luckiesn, The Science of Seeing, (New York:

D. Van Nostrand Company, $1937, \mathrm{p} \cdot \frac{1}{21}$. 2 Percy W. Cobb, Lighting for the Conservation of Vision,
(New York: National Society for Prevention of Blindness, Publication \#123, 1933) pp. 13-14. 
forty per cent when college students were considered, and ultimately reached the starting proportions of ninetyfive per cent for people over sixty years of age. These data agree favorably wi th the statistics of Luckiesh and Moss, who assert that forty per cent of the general public have defective vision. In close agreement witn the above results, the Scientific American published findings purporting to show that twenty-five per cent of school children and fifty per cent of tne adults were handicapped by impaired vision either corrected or uncorrected. 1 The conclusion to these astounding percentages impresses us with the fact that we are living in a half-seeing world.

Since seoing is a partnership of lighting and vision, attention should be concentrated not only upon correction of refractive errors, but a lso upon sight-saving illumination. Luckiesh says, "Nearsigntedness is commonly caused by inadequate intensity of 1llumination for seeing of reading matter."2 The same authority still furtner states that children are most susceptible to harm in this respect.

1 "Too Much Illumination," editorial, Scientific American, 151:8, July, 1934.

$2 \mathrm{M}$. Lucklesh, Seeing, (Baltimore: The Williams and Wilkins Company, 1931$)$ p. 7 . 
Writing from the angle of physiological reaction, Hillyer states that inadequate and improper light can cause neadaches, nervousness and even indigestion. ${ }^{I}$ To Hillyer, heavy muscular energy drain as well as increased nervous tension and irritability can, in many instances, be attributed directly to a slight continous eye strain, which the victim nimself cannot detect. The same discussion incorporated a table of recommended intensities that are considerably higher than even those of the Illuminating Engineering Society. In these recommendations, Hillyer advocates fifty to one hundred foot-candles for reading and similar tasks, while intengities below five foot-candles are declared the danger zone for any type of prolonged task. The ingidious deception involved in poor lighting is due to the fact that the human eye, on account of its adaptation ability, is a very poor light meter. Rosa says that the eyes as photometric instruments are utterly useless. 2 He also elaborates this statement by saying, "The human eye, by itself, is entirely incapable of determining with any

I E. Hillyer, op. cit.,p. $4 \mathrm{ff}$.

2 Ed. B. Rosa, Lectures on Illuminating Engineering, (Baltimore: The Johns Hopkins press, 1911) p. 386. 
accuracy the intensity of a source of light, or the intensity of illumination upon any object. The eye is also incapable of making any correct estimate of how many times one light is brighter than another."

Ability of the eye to adapt itseif to various adverse conditions of illumination of ten causes needless fatigue. In fact, we "see with our whole body." That is, eje work alone, with no other physical activity, consumes energy. Luckiesh states that twenty-five per cent of the consumption of bodily energy is dissipated by seeing. Still further, seventy per cent of muscular activity is due to impulses recelved through the ejes. Most adults use their ejes about sixteen hours per day. ${ }^{1}$ And yet, in view of these facts, very little is done to lessen the burden of the priceloss ejes.

Eye fatigue has defied, for the most part, exact quantitative measurement. Unlike the test for muscular response, complete fatigue is not indicated by failure to react. One machine, designed to measure eye fatigue, revolves a spot of light which is de to colncide with stationary spots of light by the control of patient under test. Even after hours of application to this test, the performance of the individual is just about as good as at

1 Luckiesh, op. c1t., pp. 11-16. 
the beginning. However, the eyes show signs of strain by the inflammation of the membranes, by watering, and by appearing bloodshot. In addition, the subject usually complains of tiredness. And yet, as far as quantitative measurement of fatigue is concerned, the efficiency of performance has not decreased. Hence, any lighting appraised by the ability to seo is quite inadequate. In order to provide some measure of protection against the different eye abuses, The Illuminating Engineering society, in collaboration with other learned organizations, nas attempted to recomend minimum 1llumination levels best adapted to particular tasks. One of their most recent publications was released in March, 1938, and accordingly contains recomendations based on the latest research. This code, called American Recommended Practice of School Iighting, was approved by the American Standards Association. Although this code was sponsored by the Illuminating Engineering Society and the American Institute of Architects, there were fifteen other reputable organizations that voted for the new standards. A list of these organizations is contained on the following page. A reproduction of recormended foot-candles for school lighting offered by the report is also contained on the following page.

The code specified a minimum of fifteen foot-candles for class rooms and offices. This amount practically doubles 


\begin{tabular}{|c|}
\hline 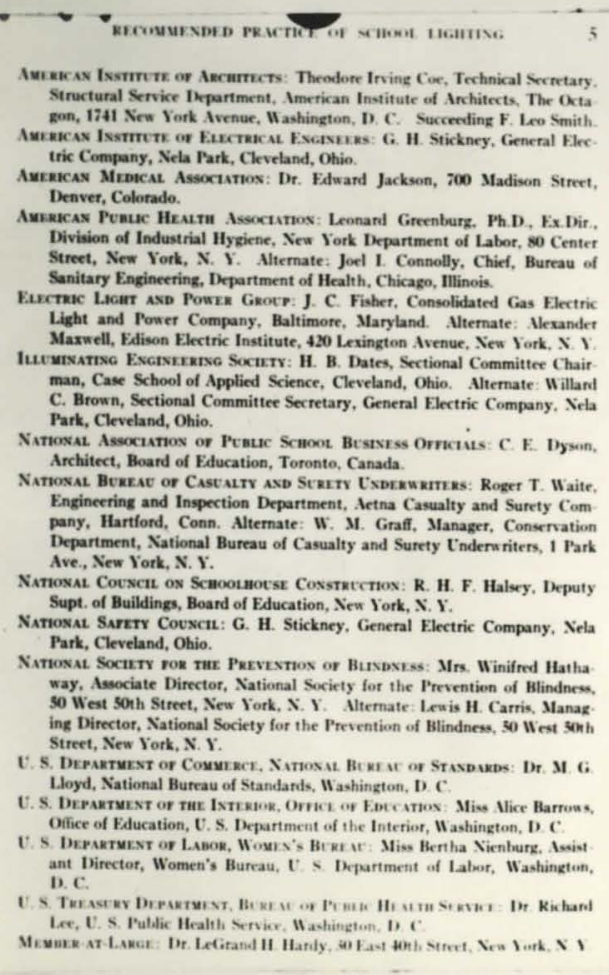 \\
\hline
\end{tabular}
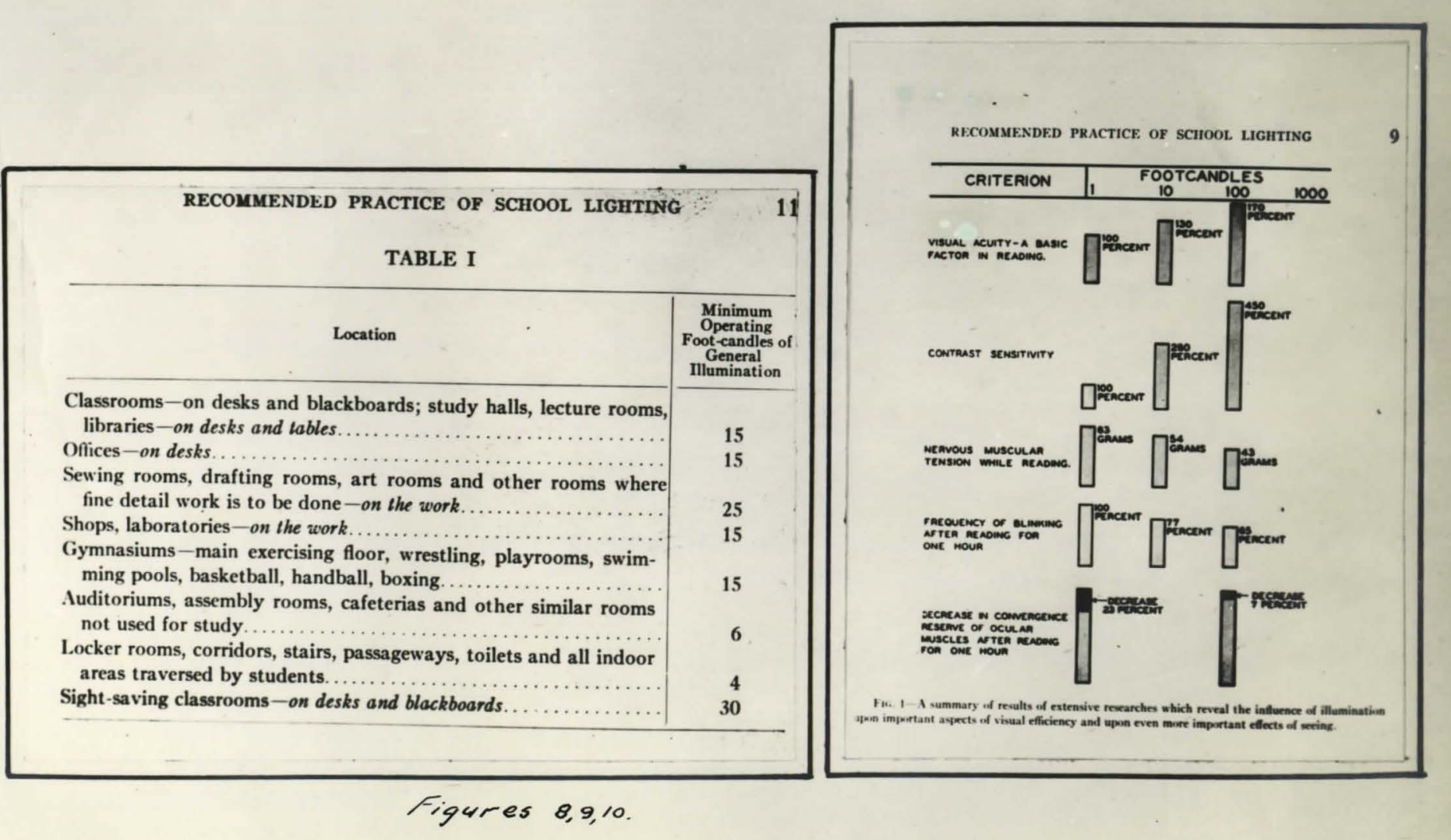
the elght foot-candie level recommended by the same groups In 1932. The objection to the increase apparently lies in the increased cost alone. One current article says, "To put fifteen foot-candes on every pupil's desk would cost United States schools untold millions $(\$ 1,000,000$ a year in New York City alone)."I

Because glare is extremely harmful, the report also advised that special attention be given to the elimination of such reflecting surfaces as glossy finish on desk tops, and glass tops on desks. Any of these, it is said, can produce severe optical strain when the eyes are exposed to the reflections for long periods of time.

Most researches on illumination emphasize the importance of the elimination of both the reflected glare of the type previously mentioned and the direct glare. The most common source of direct glare is occasioned by some light source in the line of vision. This is usually caused by unshaded tungsten bulbs that are not sufficiently high overhead. Although the actual intensity level of illumination can be greatly increased, in accordance with the inverse square law, on a given working plane by lowering the overnead light sources, this procedure is not advisable because of the

1 "Light and Heat," editorial, Time, 31:13. 
glare encountered. For the same reason, all incandescent filaments should be enclosed in translucent diffusing globes

Although there is general prejudice among those not familiar witn the facts against too much light for certain seeing tasks, this attitude is altogether unfounded scientifically. Whenever the objection is offered that too much illumination exists, the analysis of the situation usually reveals not too much illumination, but too much glare. 1

In cases where the Elare and reflection-factors have been practically nil, experiments have shown that the greatest efflciency has been obtained in such tasks as sewing with black thread on black cloth when the intensity Ievel has been increased to as high as ten-thousand footcandles. Lagerstrom is authority for the statement that "Al1 researches indicate that seeing becomes easier as tne illumination is increased apparently without bound, as long as the element of glare does not enter." 2

Another experiment reported by Moss verifies the folly of the belief tret too much illumination is harmful

1 "Too Much Illumination," edjtorial, Scientific Amer1can, 151:8 July, 1934.

2 Personal letter R. E. Iagerstrom to Ross Granam. February 23, 1938. 
and uncomf or table. In this research each subject was seated under an ordinary floor lamp equipped to deliver about eight foot-candles upon reading matter in the hands of the subject. All subjects believed that the amount of light was quite adequate for the purpose. The next step in the procedure moved the individual to a specially constructed booth in which the quantity of illumination could be controlled by the subject in accordance with his own desires and likes. He was then told to adjust the illumination to the optimum level. After this had been done, a reading of the foot-candles was taken and recorded. The mean of this controlled illumination in several hundred cases averaged 370 foot-candlos.

Sincedense shadows contribute to the degree of contrast, and hence indirectly aggravate the attendant glare, localized lighting alone, at or near the working plane, is not sanctioned. All localized lighting should be supplemented by general lighting. One investigator says that the general lighting should provide at least ten per cent of the 1llumination of the localized light source. I This recomendation is a lso justified by the fact that the eyes, in being diverted from a brilliantly 1lluminated

1 M. Luckiesh, The Science of Seoing, (Now York: D. Van Nostrand Company, $1937,, \mathrm{p}, 334$. 
working surface to darkened surroundings, are required to adapt themselves to the change by iris dilation. This requirement introduces a new muscular strain upon the eje, since adaptation from a higher to a lower level of illumination requires considerably more time and strain than adaptation for the reverse condition, even when the light differential remains the same. It requires about sixty times as long for the pupil of tne eye to dilate as it does for it to contract. This means that if looking from a darkened area to a brighter area required a few seconds for proper adjustment, then looking back again from the brignter area to the darker area will require the same number of minutes, not seconds, for proper adjus tment.

Inasmuch as the eyes are required to shift about, change focus, and provide adaptation, the muscles and nerve centers demand an enormous amount of energy during prolonged working periods. To alleviate this burden, it becomes important to provide lighting capable of creating the most effective retinal impression with the minimum amount of strain and effort.

Under higher levels of illumination, the eye has been shown to respond accordingly, by: (1) increased ability of perception as shown by Figure 12; (2) increased speed of discrimination, or rapidity with which tne eye is able to 
identify a difference, or differences, in objects, as snown by Figure 11; (3) Increased accommodation, or ability of the eye to focus upon objects at different distances; (4) improvement in sustained vision, or the ability of the eye to keep a clear view of all details of an object under continuous observation; and (5) increased speed of vision, or speed of reading, as shown by Figure 13 .

Luckiesn gives data in this respect to show that an increase in speed of vision of four-hundred per cent was brought about by an increase from two foot-candles to twelve foot-candles. ${ }^{l}$ However, Tinker states that nis own studies have shown no gain in speed of reading in light stronger than three foot-candies. 2 No data other than tnis conclusion was reported, however.

Likewise, Halsey, who is Superintendent of School Buildings in New York City, is definitely antagonistic toward increased 1llumination in the school room. One of his publisned articles charges that the researches in favor of increased light are financed by the utility companies,

I N. Luckiesh, Light and Work, (New York: D. Van Nostrand Company, 1924T p. 182. 1938.

2 "Light and Heat," editorial, Time, 31:13, March 


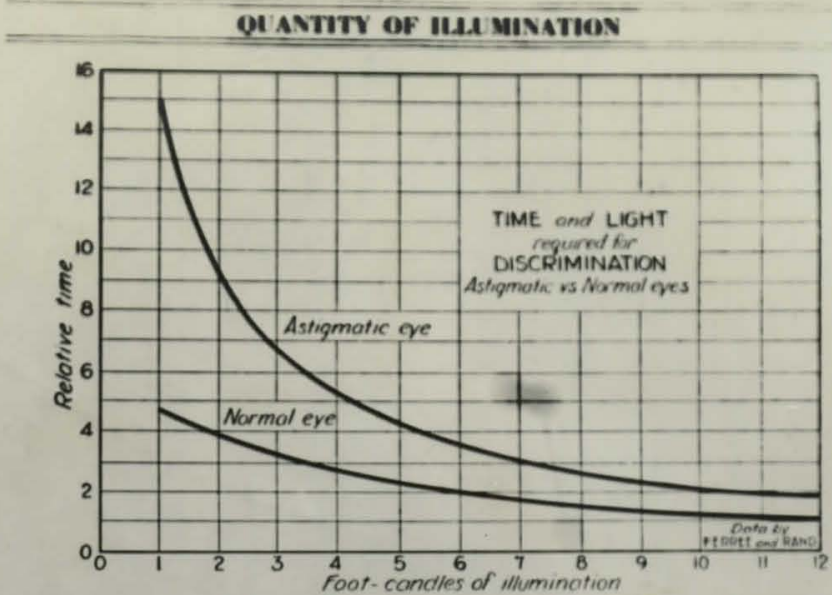

Fig. 46-Normal eyes increase in speed of discrimination $3 \frac{1}{2}$ to 1 between 1 and 12 foot-candles; astigmatic eyes show even more pronounced improvement.

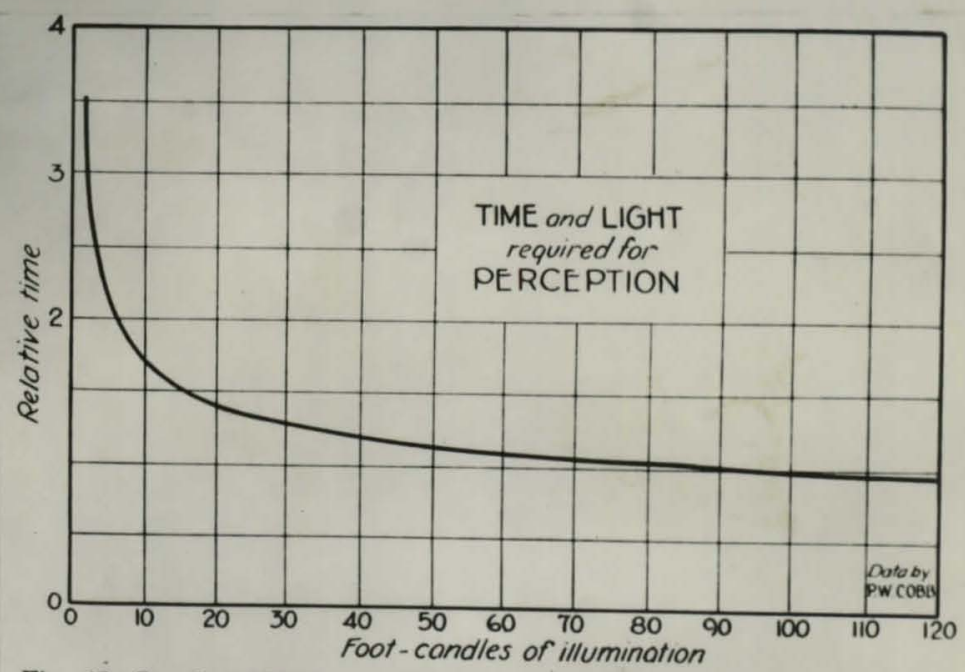

Fig. 45-It takes $3 \frac{1}{2}$ times as long for the eye to perceive a small test object under 2 foot-candles as it does under 100 foot-candles

When the illumination in a low order, these impressions will be inadequate, the eye muscles have extra work thrown upon them and they become rapidly exhausted; work is consequently retarded and mistakes are frequent.

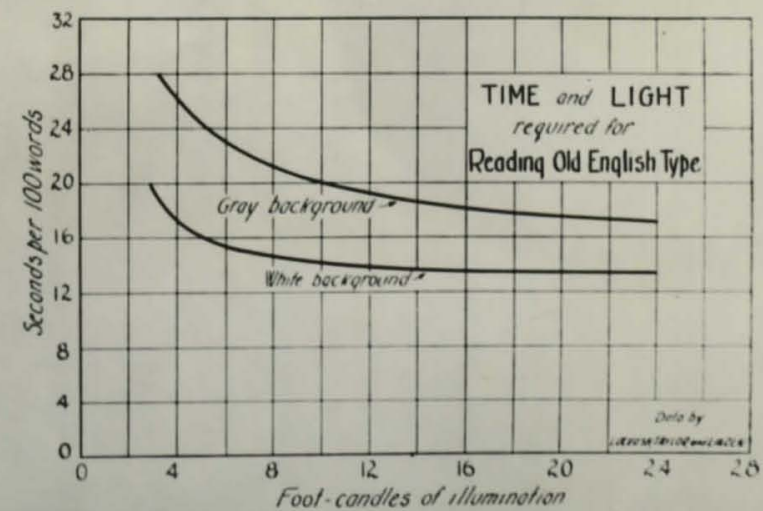

Fig. 47-Speed of reading indicates the time it takes to see; even when conditions for reading are best, i.e., black and white contrast, the eye can see $20 \%$ more quickly under good illumination. 
and hence are colored by disguised salesmanship. Halsey does not offer definite scientific reasons for his belief that $\mathrm{s} \pm \mathrm{x}$ to eight foot-candles are sufficient for reading. His conclusions are based solely on the fact that under such illumination he, himself, has noticed no 111 effects from reading for time intervals as high as three hours. An additional argument of fered by Halsey reminds us that Abraham Lincoln never received twenty foot-candles from his fireplace. I

One of the most outstanding studies snowing increased scholarship on account of better lignting was conducted by Allphin. ${ }^{2}$ In this investigation, two identical rooms were chosen, teachers were alternated, and the pupils were divided into two equal groups. One roomwas then arranged to be illuminated by photo-electric controls set to maintain a minimum level of twenty foot-candles on the desks. No change was made in the lighting equipment of the other room. The results of the test, which covered one-nundred thirty-five school days, snow, with statistical accuracy, that tne gain

1 R. H. F. Halsey, "How Kuch light for Scnoolrooms," American Scnool Board Jr·, 96:27-8 January, 1938.

2 Williard Allphin, Does Scnool Lignting Influence Scholarship, (Buffa 10: Trans. Il Iuminating Engine日ring Society, September 1936) pp. 1-12. 
in reading age of the pupils in the better lighted room was twenty-eignt per cent nigner than those in the poorly lignted room. Furthermore, the educational age also showed a ten per cent increase with a probable error of .71 . Substantiating the foregoing findings, there are other tests conducted by Albert, and reported in his treatise, Scholarship Improved by Lignt. I Jonnston's survey still further verifies the benefits received by improved classroom illumination. 2 of 4316 school children in Syracuse, 50.6 per cent of those repeating a school grade had defective viston, whereas only 14.6 per cent of tnose making normal progress had refractive errors.

A parallel case at Baltimore revealed that of 7122 children, those who possessed defective vision were more of ten chronologicaliy over-age, with respect to school age, than they were chronologically under-age.

If these studies are considered reliable, inadequate illumination, and its concomitant corollary of abnormality of vision are conclusively proved to be closely related to

\footnotetext{
I E. C. Albert, "Scholarship Improved by Light," Trans. Illuminating Engineering Society, $28: 866,1933$.

$2 \mathrm{H}$. I. Jonnston, "Better School Lignting Pays," Electrical World, 104:1078 July, 1934.
} 
retardation in educational progress of school children. Measurements of intensities of illumination before and after cleaning glass areas yield startling results. In many cases, the increase in light value is as much as five to ten times, and it is not uncommon to increase the illumination intensity from an average of one foot-candie with dirty glass to as high as fifteen foot-candles with clean glass.

Hibben, of Westinghouse, states, as an authority, that one billion dollars were spent one year (1932) for artificial light. 1 The same autnority estimated that proper maintenance in the form of frequent cleaning of bulbs, fixtures, luminares, and glass areas could have saved three hundred miliion dollars of the total. In the same discourse, emphasizing that "water is cheaper than watts," Hibben concludes, "I would say that if alI our lighting installations and their immediate surroundings could be cleaned and reconditioned today, then the illumination that this nation enjoyed last night would be well-nigh doubled tonight."

Cleanliness is a lso considered paramount by Cady, who goes still further in his recommendations for the

1 "Dirt Adds Millions To Light Costs," editorial, Literary Digest, $115: 26$, Marcn 4, 1933 . 
maintenance of light colored walls and cellings for proper schoolroom lighting. The specific recommendations concern the reflection-factors of walls which should range between .30 and .50. The preferred colors are light warm gray, light buff, dark cream, and light olive green. Ceilings should have reflection-factors of sixty-five per cent. Ceiling colors should be limited to white or light cream. Desk tops should have a reflection-factor not exceeding twenty-five per cent, in order to eliminate the possibility of glare from this source. 1

In consideration of the gradual depreciation of light as the result of the accumulation of opaque dirt, and in viow of the fact that the numan eye is an extremely unreliable light meter, the ideal solution of the classroom lignting problem is one that completely removes the human element in the control of artificial illumination. Automatic control has been successfully installed and operated in many school units including laboratory schools, sight-saving classes, and ultra-modern public school buildings. In such installations, adjustable photo-electric relays are set to turn on tne artificial illumination whenever the natural

I F. E. Cady and Dates, H. B., Illuminating Engineering, (New York: John Wiley and Sons, Inc., 1925) pp. 35r-358. 
light falls to a predetermined minimum. Similarly, when the total foot-candles reach a given level, the artificial luminares are automatically switched off. An arrangement of this sort provides optimum lighting conditions coupled with minimum current consumption.

It is, indeed, unfor tunate that most school systems cannot enjoy the benefits of these photo-electric relays. Altnough quantity production in their manufacture has reduced the initial cost of these units to the extent that the price is no longer prohibitive for any school system of sound financial status, yet scnool executives are reluctant to adopt such improvements. This attitude in some cases takes the form of definite antagonism towards any "new-fangled frills." In other instances, a possible explanation is found in the fact that few lay school board members are thoroughly conversant with the need for adequate and proper illumination.

In this age of mechanization and idolatry of efficiency in all other lines of activity, it is very strange that more attention has not been devoted towards the perfection of the conditions of sering. 
ChaPTER IV

SOURCES AND TREATMENT OF DATA 
SOURCES AND TREATMENT OF DATA

This classroom illumination study included the examination of one room from each of the eight buildings comprising the entire Jeffersonville, Indiana, public school system. These buildings are known as: Rose Hill; Chestnut Street; Spring Hill; Port Fulton; Junior High School; Senior Hign School; Ingramville; and Taylor Colored. ${ }^{I}$

In eacn of these buildings, after a preliminary determination of light values, a room was chosen which would best represent the average conditions of illumination for the building. This choice of the particular room to be examined included such considerations as; direction of light exposure; window area; reflection factors of the interior wall surfaces; and the type of artificial light sources. Every attempt was made to be sure that the room chosen for study was not exceptional in any of the above mentioned characteristics.

It is not to be assumed that the room selected was intended to serve as a typical unit from which general conclusions could be drawn for the entire building. This study does not, in any respect, purport to establish the

1 cf. post. pp. $47-49$ 
existence of identical and similar illumination conditions between the rooms studied and those not studied. The rooms examined were merely units for specimen sampling. The raw data upon which this work was based consisted of more than 2,000 separate foot-candle determinations. The actual readings, for purposes of classification and systematization, were recorded on printed file cards three by five inches in size. This card provided space for the entry data for the various positions in any of the seat rows. The form of this pimary record card, which included all the more important facts concerning the conditions of illumination, is reproduced on the following page.

The actual collection of data and various meter readings was carried on throughout the school year ending 1938. A much more complete sampling was obtained by extending the period of observation over an interval which included different seasons. To guarantee still further a random cross-section of the illumination conditions as the actualiy existed, the time of day at which the readings were taken was varied as much as possible.

No a ttempt was made to improve the light conditions in any room, before the readings were taken, by such procedure as adjusting the window shades or by turning on the artificial lights. Thus, the results obtained are indicative of the actual conditions encountered in the 
classrooms.

After these readings were separated according to the bullding involved, the type of natural light conditions, and the location of the desk rows, a frequency distribution was tabulated for each group. This procedure resulted in forty-eight such arrangements. Then for each of these groups, the mean illumination, the sigma of the distribution, and the probable error of the average were calculated for each of the forty-eight tabulations. Thus, the accepted standard measures of central tendency, variab1lity, and reliablitty were obtained.

Interpretation of these last two measures in terms of probability defines the sigme of the distribution as setting the upper and lower limit of varlation from the average within which 68.26 per cent of all cases will fall. The probable error of the average indicates the limits in which fifty per cent of all cases would fall if a frequency distribution were made of an infinite number of averages obtained in similar manner.

With the mean illumination on the desk tops, and position of the desls rows as the co-ordinates, curves for each representative room were drawn representing the illumination level distribution for botn the bright and the dull days. The graph representing the bright day conditions was represented in all drawings by the red line, while the 
dull day conditions were indicated by the black line. The green line represented the desirable recommended minimum 11 ght level.

In order to give the proper identification of the rooms studied, their location in the building with reference to other rooms, their directional orientation, and their window position and number, complete floor plans for both first and second floors of all elght buildings are given in the appendix of this thesis.

Also given elsewhere herein are the tables containing the statistical analysis, the form she日t used for collection and recording the physical properties of the rooms, and a summary of al 1 calculated results. 2

1 Gf. post. Appendix, pp. 98-110.

2 Cf. post. Appendix, pp. 110. 


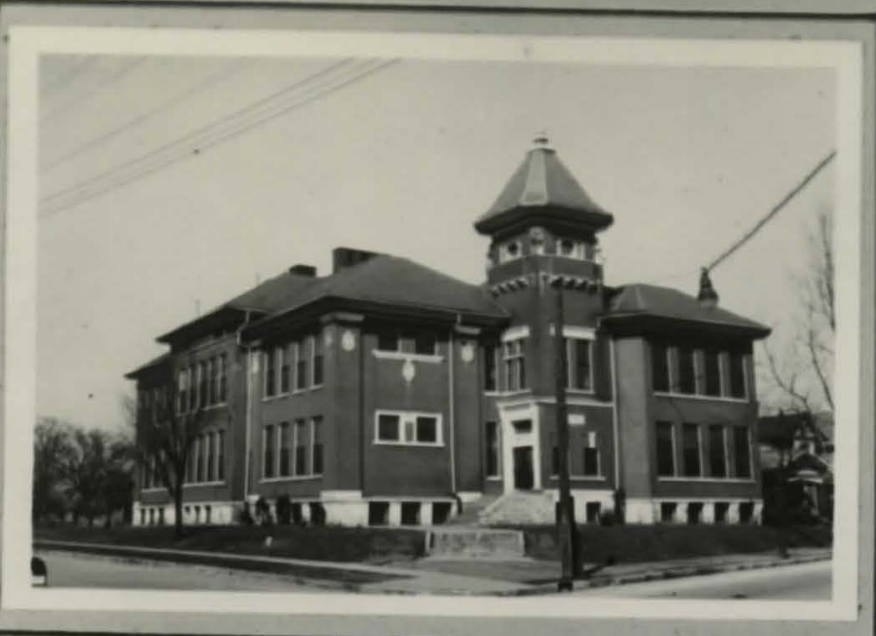

SPRING HILI ELEMENTARY

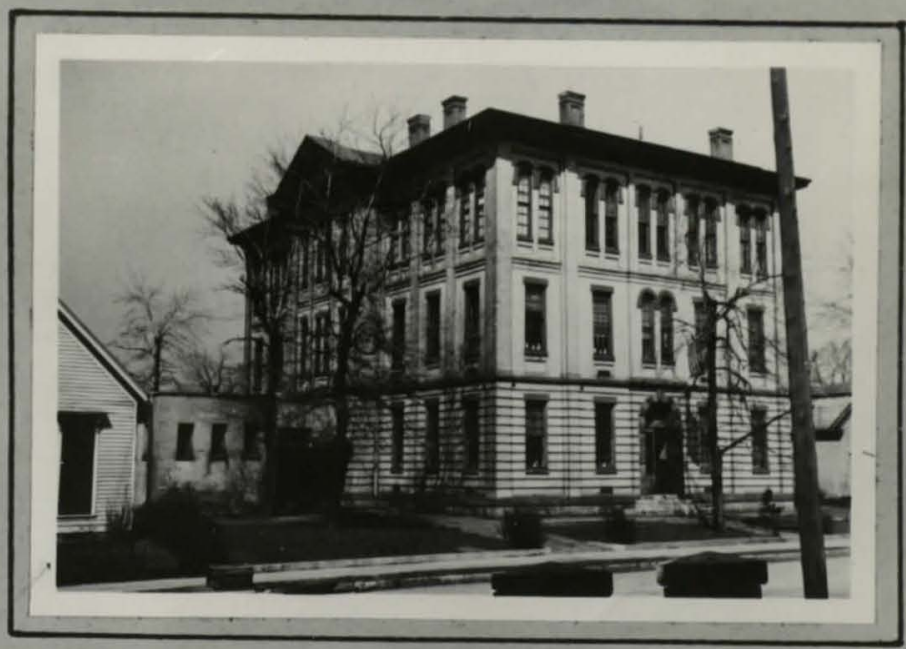

CHESTNUT STREET ELEMENTARY

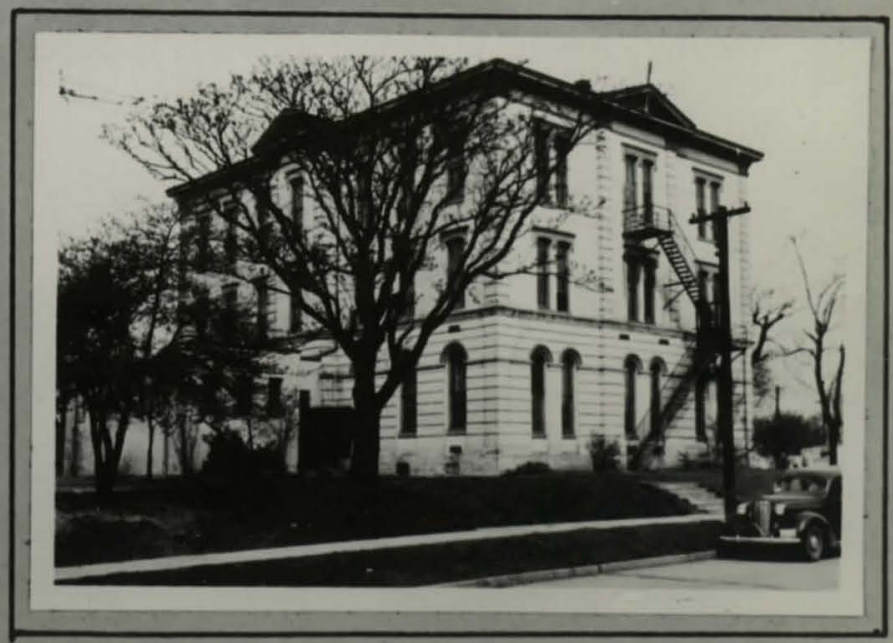

ROSE HILL ELEMENTARY Figures 10,15,16. 


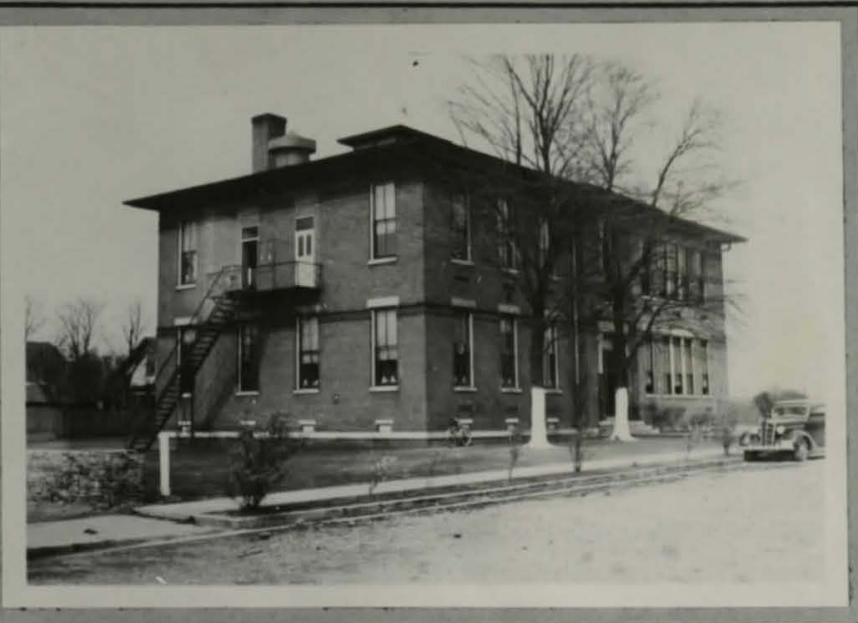

PORT FULTON BLEMENTARY

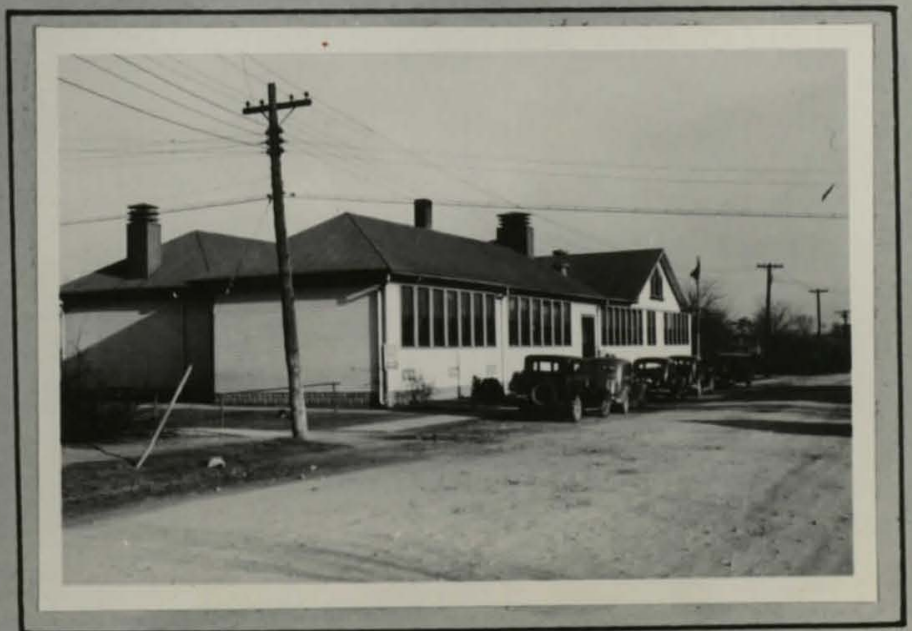

INGRAMVILLE ELEMENTARY

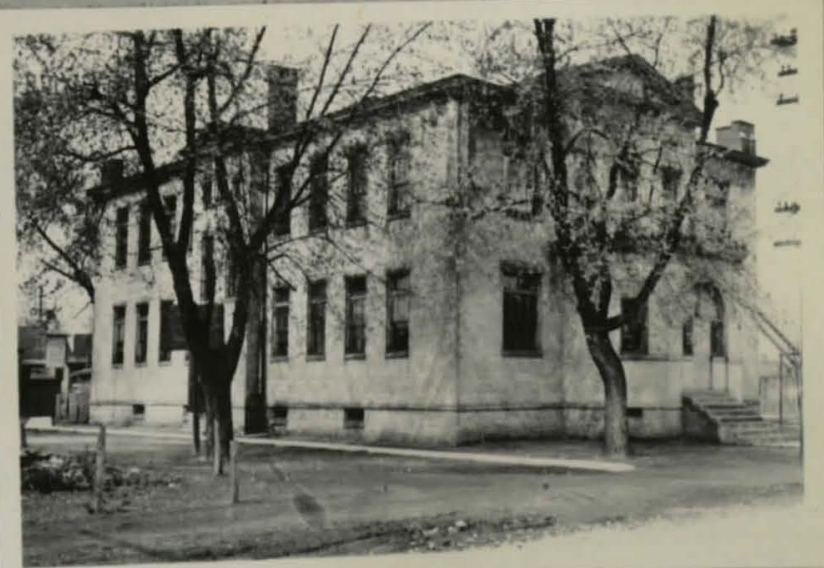

TAYLOR COLORED Fiqures, $1 \geqslant 18,19$. 


\section{BUILDINGS SURVEYED}

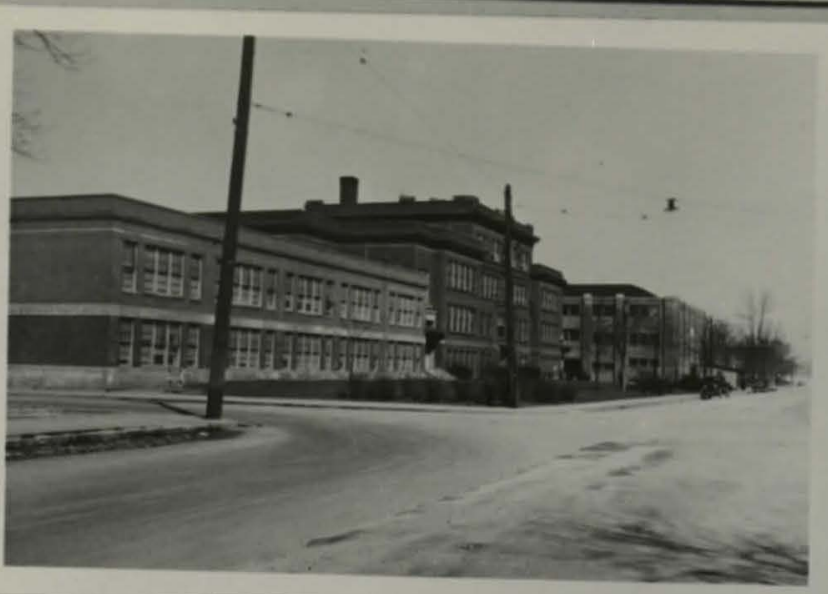

JUNIOR HIGH SCHOOL

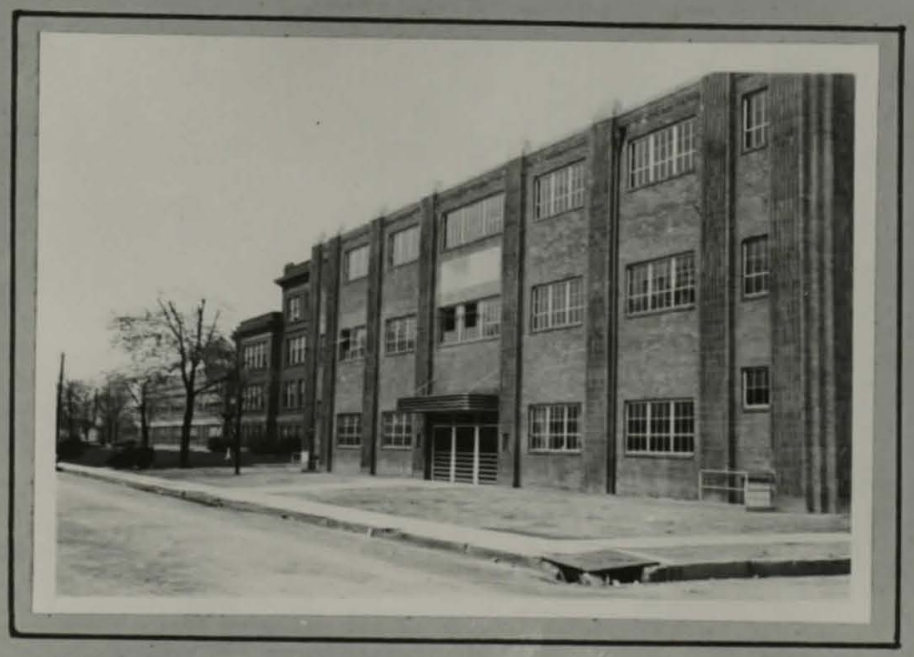

SENIOR HIGH SCHOOL 


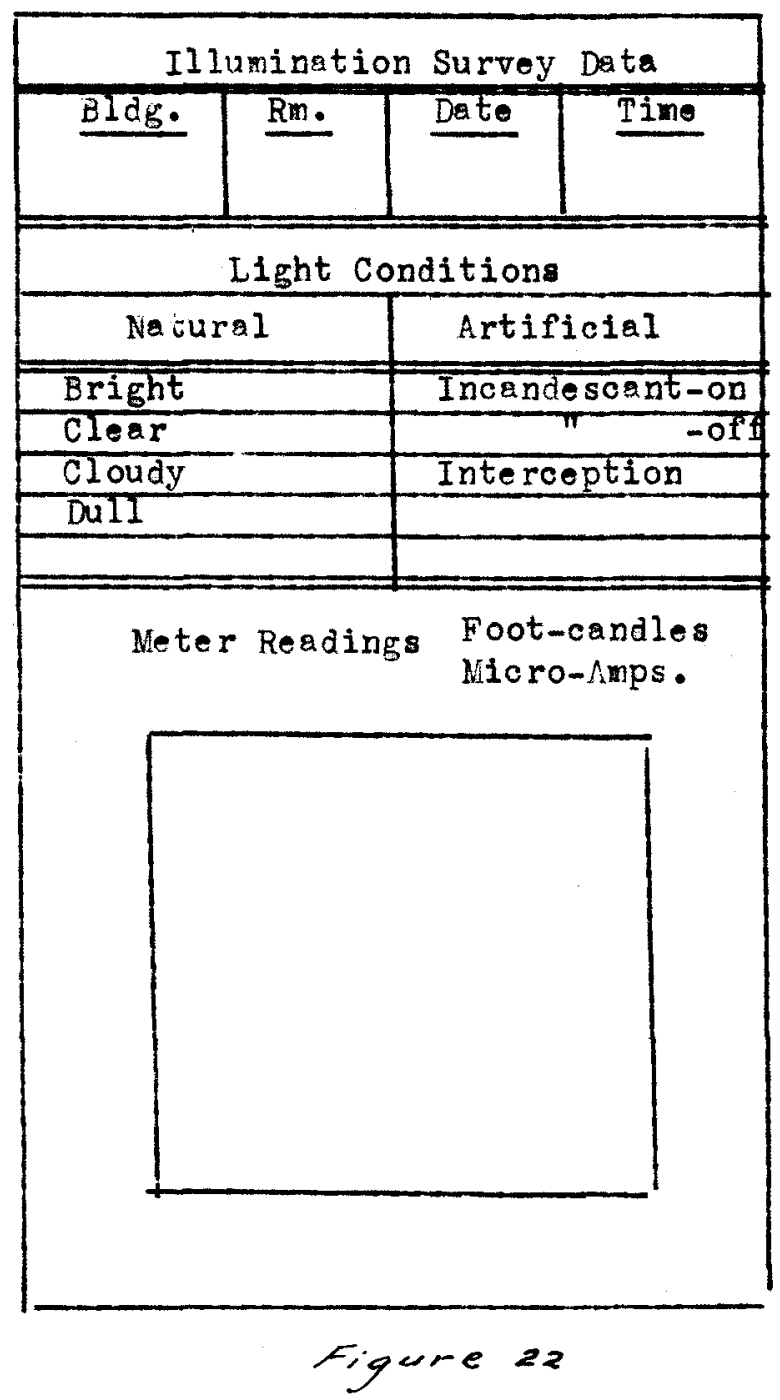


CHAPTER V

STATISTICAL AND GRAPHICAL ANALYSIS OF FINDINGS 


\section{STATISTICAL AND GRAPHICAL ANALYSIS \\ OF FINDINGS}

\section{Although different foot-candle measurements snowed} that the illumination in the different rooms varied considerably over a ratner wide range of values, yet when the statistical reliablity was computed, it was found to be high.

An authority, previously quoted, predicted this possible result when he said:

"Visual data taken under identical conditions insofar as is posible are often in wide variance. If sufficient observations are taken, the average value for a given condition can be shown to be of a high degree of reliability. These are pot the ordinary a verages of arithmetical means."

The same author then gives the customary approved formulae for the determination of mean probable errors.

The curves that follow, showing the decrease across the rooms of illumination level are, for the most part, entirely self-explanatory.

It will be noted that the entire length of these curves does not follow Kepler's inverse square law of light propagation. This apparent irregularity was fully anticipated,

1 M. Luckiesh, Seeing, (Baltimore: The Williams and Wilkfns Company, $193 i$ ) p. 50 . 
because the "inverse square law does not hold unless the distance between source and object is at least ten times the maximum dimension of the source."I

The important facts revealed by these curves are twofold. First, the drop is rapid for all curves throughout the extremely short distance represented by the first two rows of desks. This rapid initial drop is as outstanding as the small amount of relative difference between the curves for the bright days and for the dull days. The curves indicate that, although the weather conditions may produce a great difference in illumination near the windows, large differences fail to exist more than a few feet from the windows.

In fact, the only irregularity of any note in any of the curves occurs in the graph for Taylor Colored School, Figure 28. The intersection of the red line with the black line reveals the fact that for certain room areas the light on dull days was of higher order than the light values in the same area for bright days.

The nature of this discrepancy would suggest some fundamental errors either in the tabulation of data or the

$1 \mathrm{M}$. Luckiesh, Light and Work, (New York: D. Van Nostrand Company, 1924) p. I09. 
calculation of the results for this one particular room. To eliminate this possibility, all figures and calculations were carefully rechecked, and were found to be correct as listed. Although the writer has no explanation for this one exception, it should be pointed out that this one room was architecturally different from all others surveyed. As shown by the floor plans, this is the only room studied which had the major window area located at the rear of the room.

To read the various graphs and to interpret correctly the related date that follows, a detailed description is warranted. Since the several series of graphs and data analyses are similar, wi th the exception of their application and numerical magnitude, only one of each kind will be discussed. An understanding of the remaining tables and figures will be obtained by extending the analogous explanation.

For example, Figure 23 snows the decrease in illumination by desk rows across room \#I of spring Hill elementary school. The conditions for both tne bright days and the dull days are indicated by different colored curves plotted on the same coordinate axes.

The ordinates of the vertical axis represent the amount of illumination in foot-candles. The abscissas of the 
norizontal axis indicate the various positions of desk rows. The left-hand extremity of the horizontal axis locates the desk row adjacent to the windows of the room. Likewise, the right-hand extremity indicates the desk row nearest the wall opposite the windows. The vertical lines between these two extremes represent the positions of the intervening desk rows.

The contour of the red curve reveals that for bright days the illumination received by the desk row adjacent to the windows was approximately eighty-six foot-candles. This mean value progressively decreased to twenty foot-candes for the center desk row and finally became nine foot-candles for the desk row most remotely removed from the windows. For dull days, the black curve shows values of forty-three, ten, and five for the same corresponding positions mentioned above. The green line indicates the uniform illumination level of fifteen foot-candles, which is the minimum recommended by the Illuminating Engineering Society.

Table I supplies, in the first column, the values upon which the curves of Figure 23 were plotted. In addition, Table I not only furnisned the variability of the frequency tabulation in terms of the sigma of the distribution, but also provides the figures for the reliability of the calculations in terms of the probable error of the average. The interpre- 
tations of these last two statistical terms have been given previously in this study.

Tables IX and $X$ apply respectively to the bright and dull day conditions for the room treated in Figure 23. Each table is in reality tnree separate tables. These separate parts are devoted respectively to the desk row adjacent to windows, the desk row at the center of the room, and the desk $r$ ow most remotely removed from the windows. Each of the tnree subdivisions of tnese tables is merely tne standardized form for the calculation of statistical constants by the "short-method." All results are labeled by tne customary symbols peculiar to tnis branch of investigation. 
DECREASE IN ILLUMINATION BY DESK ROWS ACROSS ROOM \#I,SPRING HILL SCHOOL,

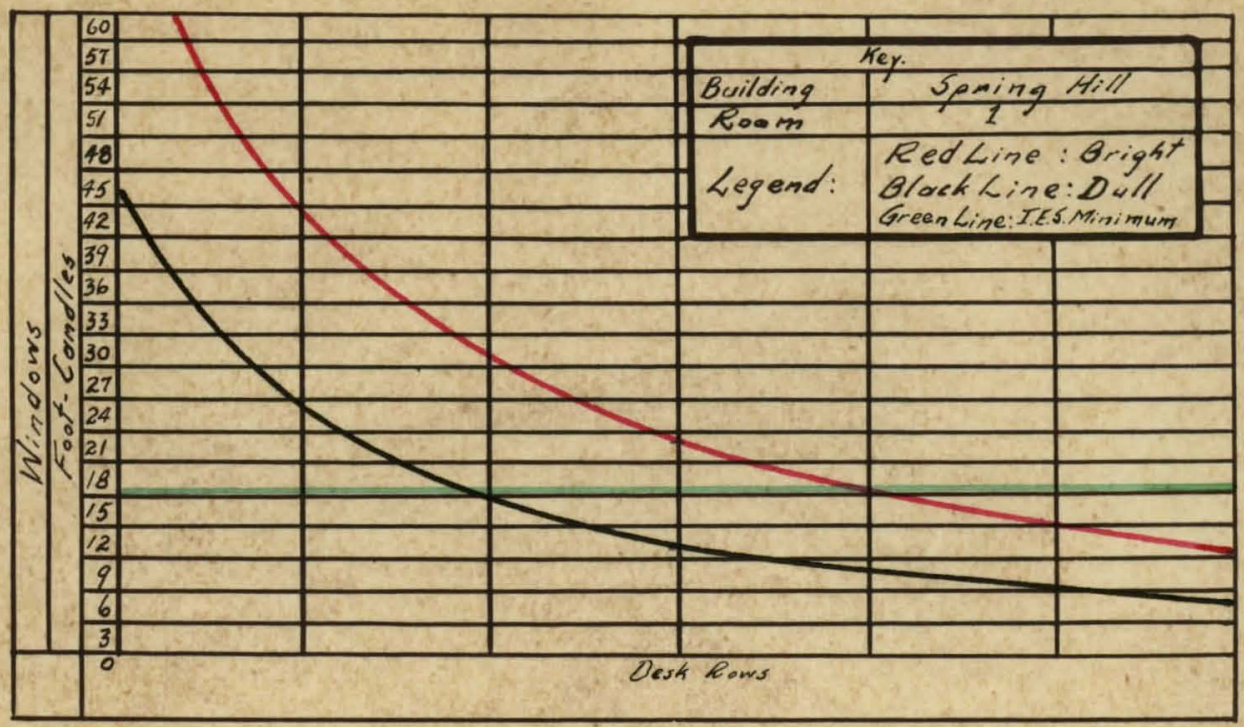

ETGURE 23

Illumination Level Distribution Cunves

TABLE I

Statistical Data for Curves Above

\begin{tabular}{|c|c|c|c|}
\hline & $\begin{array}{c}\text { Mean Illumination } \\
\text { Foot Landles } \\
\text { Desk-Top. }\end{array}$ & $\frac{\text { Variabilit/ }}{\sigma_{\text {dist }}=\left(\frac{E F D^{2}}{N} c^{2}\right)^{1 / 2}}$ & $\begin{array}{l}E_{e} \text { liability } \\
\rho E_{\text {av }}=\frac{.6745}{\sqrt{N}}\left(\text { dist }^{2}\right)\end{array}$ \\
\hline \multirow{3}{*}{ है } & 85.97 & 39.99 & 4.32 \\
\hline & 19.78 & 6.27 & .62 \\
\hline & 9.26 & 3.17 & 32 \\
\hline \multirow{3}{*}{$\begin{array}{l}0 \\
0^{2} \\
5 \\
0\end{array}$} & 42.50 & 18.40 & 2.10 \\
\hline & 9.82 & 4.02 & 40 \\
\hline & 4.65 & 2.33 & 22 \\
\hline
\end{tabular}


TABLE $I X$

\begin{tabular}{|c|c|c|c|c|c|c|c|c|c|c|c|c|c|c|c|c|c|}
\hline \multicolumn{6}{|c|}{ Seats } & \multicolumn{6}{|c|}{ Seats of Center } & \multicolumn{6}{|c|}{ Seat's Afjocent to Opposite Woll } \\
\hline Step & m.d.pt. & $F$ & 0 & $F D$ & $F D^{2}$ & Stop & Mid-PA. & $F$ & 0 & Fo & $F D^{2}$ & Step & Mid-Ax & $F$ & 0 & $F D$ & $F D^{2}$ \\
\hline $145+150$ & 147.5 & 2 & 11 & 22 & 242 & $29-30$ & 29.5 & 4 & 12 & 48 & 576 & $29-30$ & 29.5 & & & & \\
\hline $140-145$ & 142.5 & 2 & 10 & 20 & 200 & $28-29$ & 28.5 & 0 & 11 & & & $28-24$ & 28.5 & & & & \\
\hline $135-110$ & 137.5 & 1 & 9 & 9 & 81 & $27-28$ & 27.5 & 0 & 10 & & & $27-28$ & 27.5 & & & & \\
\hline $130-135$ & 132.5 & 0 & 8 & & & $26-27$ & $26.5^{-}$ & 1 & 9 & 9 & 81 & $26-27$ & 26.5 & & & & \\
\hline $125-130$ & 127.5 & 2 & 7 & 14 & 98 & $25-26$ & $25.5^{-}$ & 9 & 8 & 72 & 576 & $25-26$ & 25.5 & & & & \\
\hline $20-126$ & 122.5 & 6 & 6 & 36 & $2 / 6$ & $24-25$ & 24.5 & 3 & 7 & 21 & 147 & $24-25$ & 24.5 & & & & \\
\hline $115-120$ & 117.5 & 0 & 5 & & & $23-24$ & 23.5 & 0 & 6 & & & $23-24$ & 23.5 & & & & \\
\hline $110-115$ & $1 / 2.5$ & 0 & 4 & & & $22-23$ & 22.5 & 1 & 5 & 5 & 25 & $22-23$ & 22.5 & & & & \\
\hline $105-110$ & 107.5 & 0 & 3 & & & $21-22$ & 21,5 & 1 & 4 & 4 & 16 & $21-22$ & 21.5 & & & & \\
\hline $100-105$ & 102.5 & 4 & 2 & $8+109$ & 16 & $20-21$ & 20.5 & 10 & 3 & 30 & 90 & $20-21$ & 20.5 & & & & \\
\hline $95 \div 100$ & 97.6 & 0 & 1 & & & $19-20$ & 195 & 0 & 2 & & & $19-20$ & 19.5 & & & & \\
\hline $90-95$ & 92.5 & 0 & 0 & 0 & 0 & $18-19$ & 10.5 & 1 & 1 & $1+190$ & 1 & $18-19$ & 18.5 & & & & \\
\hline $85-90$ & 87.5 & 2 & -1 & -2 & 2 & $17-18$ & 17.5 & 2 & 0 & 0 & 0 & $17-18$ & 17.5 & & & & \\
\hline $80-85$ & 82.5 & 5 & -2 & -10 & 20 & $16-17$ & 16.5 & 1 & -1 & -1 & 1 & $16-17$ & 16.5 & & & & \\
\hline $75-80$ & 72.5 & 0 & -3 & & & $15-16$ & 15.5 & 3 & -2 & -6 & 12 & $15-16$ & 15.5 & 4 & 6 & 24 & 144 \\
\hline $70-75$ & 72.5 & 0 & -4 & & & $14-15$ & 14.5 & 0 & -3 & & & $14-15$ & 14.5 & 0 & 5 & & \\
\hline $65-70$ & 67.5 & 1 & -5 & -5 & 25 & $13-14$ & 13.5 & 0 & -4 & & & $13-14$ & 13.5 & 2 & 4 & 8 & 32 \\
\hline $60-65$ & 62.5 & 3 & -6 & -18 & 108 & $12-1.3$ & 12.5 & 5 & -5 & -25 & 125 & $12-13$ & 12.5 & 2 & 3 & 6 & 18 \\
\hline $55-60$ & 57.5 & 0 & -7 & & & $11-12$ & 11.5 & 0 & -6 & & & $11-12$ & 11.5 & 1 & 2 & 2 & 4 \\
\hline $50-55$ & 52.5 & 1 & -8 & -8 & 64 & $10-11$ & 10.5 & 1 & -7 & -7 & 49 & $10-11$ & 10.5 & 12 & 1 & $12+52$ & 12 \\
\hline $15-50$ & 47.5 & 3 & -9 & -27 & 243 & $9-10$ & 9.5 & 2 & -8 & -16 & 128 & $9-10$ & 9.5 & 5 & 0 & 0 & 0 \\
\hline $70-45$ & 42.5 & 2 & -10 & -20 & 200 & $8-9$ & 8.5 & 2 & -9 & -18 & 162 & $8-9$ & 8.5 & 7 & -1 & -7 & 7 \\
\hline 3540 & 375 & 0 & -11 & & & $7-8$ & 2.5 & 1 & -10 & $-10-93$ & 100 & $7-8$ & 7.5 & 0 & -2 & & \\
\hline $30-35$ & 32.5 & 1 & -12 & -12 & 144 & $6-7$ & 6.5 & & & & & $6-7$ & 6.5 & 1 & -3 & -3 & 9 \\
\hline 2530 & 27.5 & 0 & -13 & & & $5-6$ & 5.5 & & & & & $5-6$ & 5.5 & 8 & -4 & -32 & 128 \\
\hline $20-25$ & 22.5 & 1 & -14 & -14 & 196 & $4-5$ & 4.5 & & & & & $4-5$ & 45 & 3 & -5 & -15 & 75 \\
\hline $15-20$ & 17.5 & 2 & -15 & -30 & 450 & $3-4$ & 3.5 & & & & & $3-4$ & 3.5 & 1 & -6 & $-6-63$ & 36 \\
\hline $10-15$ & 12.5 & 1 & -16 & $-16-162$ & 256 & $2-3$ & 2.5 & & & & & $2-3$ & 2.5 & & & & \\
\hline $5-10$ & 7.5 & & & & & $1-2$ & 1.5 & & & & & $1-2$ & 1.5 & & & & \\
\hline $0-5$ & 2.5 & & & & & $0-1$ & 0.5 & & & & & $0-1$ & 0.5 & & & & \\
\hline$c$ & $=-1.307$ & 39 & & -51 & 2561 & c & $=2.276$ & 47 & & +107 & 2089 & $c=$ & $=-239$ & 46 & & -11 & 465 \\
\hline$\frac{c^{2}}{c}=$ & $=\frac{1.708}{=-6.54}$ & $A v \cdot d$. & $=85.97$ & $\sigma_{\text {dist. }}$ & $=39.98$ & $c^{2}$ & $=5.180$ & $A v \cdot d i$ & $=19.78$ & Odist & $=6.27$ & $c^{2}=$ & .057 & $A_{V} \cdot d$ & $=9.26$ & $\sigma_{\text {dist. }}$ & $=3.17$ \\
\hline & & & $E_{\alpha r}=$ & 4.319 & & & & & $E_{a r}=$ & .617 & & & & & $E_{a r}=$ & .315 & \\
\hline Sta & itistic & $\%$ & ralys & is of. & Data & & & & Build, & $\operatorname{lng} 50$ & & Roo & om: 2 & & nditic & ons: & ighy \\
\hline
\end{tabular}


TABLE X

\begin{tabular}{|c|c|c|c|c|c|c|c|c|c|c|c|c|c|c|c|c|c|}
\hline \multicolumn{6}{|c|}{ Seats Adjacent to Windows } & \multicolumn{6}{|c|}{ Seats of Center } & \multicolumn{6}{|c|}{ Seats Aljocent to Opposite Woll } \\
\hline Step & Mid.P. & $F$ & 0 & Fo & $F D^{2}$ & stop & Midetet & $F$ & $D$ & $F 0$ & $F D^{2}$ & Step & Mif.Pt & $F$ & 0 & FD & $F D^{2}$ \\
\hline $45-150$ & 147.5 & & & & & $29-30$ & 29.5 & & & & & $29-30$ & 29.5 & & & & \\
\hline $140-145$ & 142.5 & & & & & $28-29$ & 28.6 & & & & & $28-29$ & 28.5 & & & & \\
\hline $135-180$ & 137.5 & & & & & $27-28$ & 27.5 & & & & & $27-28$ & 27.5 & & & & \\
\hline$(30-135$ & 132.5 & & & & & $26-27$ & $26.5^{-}$ & & & & & $26-27$ & $26.5^{\circ}$ & & & & \\
\hline $25-130$ & 127.5 & & & & & $25-26$ & $25.5^{-}$ & & & & & $25-26$ & 25.5 & & & & \\
\hline $200-126$ & 122.5 & & & & & $24-25$ & 24.5 & & & & & $24-25$ & $24.5^{-}$ & & & & \\
\hline $115-120$ & 117.5 & & & & & $23-24$ & 23.5 & & & & & $23-24$ & 23.5 & & & & \\
\hline $110-115$ & $112.5^{\circ}$ & & & & & $22-23$ & 22.5 & & & & & $22-23$ & 22.5 & & & & \\
\hline $105-110$ & 107.5 & & & & & $21-22$ & 21.5 & & & & & $2 /-22$ & 21.5 & & & & \\
\hline $100-105$ & 102.5 & & & & & $20-21$ & 20.5 & & & & & $20-21$ & 20.5 & & & & \\
\hline $95 \% 100$ & 97.6 & & & & & $19-20$ & 19.5 & 1 & 10 & 10 & 100 & $19-20$ & 19.5 & & & & \\
\hline $90-95$ & 92.5 & 1 & 10 & 10 & 100 & $18-19$ & 10.5 & 0 & 9 & & & $18-19$ & 18.5 & & & & \\
\hline $85-90$ & 87.5 & 0 & 9 & & & $17-18$ & 17.5 & 0 & 8 & & & $17-18$ & 17.5 & & & & \\
\hline $80-85$ & 82.6 & 1 & 8 & 8 & 64 & $16-17$ & 16.5 & 1 & 7 & 7 & 49 & $16-17$ & 16.5 & & & & \\
\hline $75-80$ & 77.5 & 1 & 7 & 7 & 49 & $15-16$ & 15.5 & 3 & 6 & 18 & 108 & $15-16$ & 15.5 & & & & \\
\hline $70-75$ & 72.5 & 1 & 6 & 6 & 36 & $14-15$ & 19.5 & 1 & 5 & 5 & 25 & $14-15$ & 14.5 & & & & \\
\hline $65-70$ & 67.5 & 0 & 5 & & & $13-14$ & 13.5 & 4 & 4 & 16 & 64 & $13-14$ & 13.5 & & & & \\
\hline $60-65$ & 62.5 & 2 & 4 & 8 & 32 & $12-13$ & 12.5 & 6 & 3 & 18 & 54 & $12-13$ & 12.5 & 1 & 9 & 9 & 81 \\
\hline $55-60$ & 52.5 & 0 & 3 & & & $11-12$ & 11.5 & 2 & $z$ & 4 & 8 & $11-12$ & 11.5 & 0 & 8 & & \\
\hline $50-55$ & 52.5 & 3 & 2 & 6 & 12 & $10-11$ & 10.5 & 8 & 1 & 8 & 8 & $10-11$ & 10.5 & 2 & 7 & 14 & 98 \\
\hline $45-50$ & 47.5 & 5 & 1 & $5+50$ & 5 & $9-10$ & 9.5 & 3 & 0 & $0+86$ & 0 & $9-10$ & 9.5 & 1 & 6 & 6 & 36 \\
\hline $70-45$ & 42.5 & 3 & 0 & 0 & 0 & $8-9$ & 8.5 & 3 & -1 & -3 & 4 & $8-9$ & 8.5 & 2 & $\delta$ & 10 & 50 \\
\hline 3540 & 375 & 3 & -1 & -3 & 3 & $7-8$ & 7.5 & 1 & -2 & -2 & 4 & $7-8$ & 7.5 & 0 & 4 & & \\
\hline $30-35$ & 32.5 & 7 & -2 & -14 & 28 & $6-7$ & 6.5 & 4 & -3 & -12 & 36 & $6-7$ & 6.5 & 5 & 3 & 15 & 45 \\
\hline $25-30$ & 27.5 & 3 & -3 & -9 & 27 & $5-6$ & 5.5 & 3 & -4 & -12 & 48 & $5-6$ & 5.5 & 6 & 2 & 12 & 24 \\
\hline $20-25$ & 22.5 & 2 & -4 & -8 & 32 & $4-5$ & 4.5 & 2 & -5 & -10 & 50 & $4-5$ & 4.5 & 10 & 1 & $10+76$ & 10 \\
\hline $15-20$ & 17.5 & 2 & -5 & -10 & 50 & $3-4$ & 3.5 & 3 & -6 & -18 & 108 & $3-4$ & 3.5 & 11 & 0 & 0 & 0 \\
\hline $10-15$ & 18.5 & 1 & -6 & $-6-50$ & 36 & $2-3$ & 2.5 & 2 & -7 & $-|4-7|$ & 98 & $2-3$ & 2.5 & 15 & -1 & $-15-15$ & 15 \\
\hline $5-10$ & 7.5 & & & & & $1-2$ & 1.5 & & & & & $1-2$ & 1.5 & & & & \\
\hline $0-5$ & 2.5 & & & & & $0-1$ & 0.5 & & & & & $0-1$ & 0.5 & & & & \\
\hline$c=$ & 0 & 35 & & 0 & 474 & \multirow{2}{*}{\multicolumn{2}{|c|}{$\begin{array}{l}c=.319 \\
c^{2}=.102\end{array}$}} & 47 & & +15 & 764 & $c=$ & 1.15 & 53 & & +61 & 359 \\
\hline \multirow[t]{2}{*}{$\begin{array}{l}c^{2}=-0 \\
c=0\end{array}$} & & \multicolumn{4}{|c|}{ Ar. dist. $=42.5 \sigma_{\text {dist }}=18.4$} & & & \multicolumn{4}{|c|}{$A r_{\text {dist. }}=9.82 \sigma_{\text {dist. }}=4.02$} & $c^{2}=$ & 1.323 & \multicolumn{2}{|c|}{$A r_{\text {dist. }}=4.65$} & \multicolumn{2}{|c|}{$\sigma_{\text {dist. }}=2.33$} \\
\hline & & \multicolumn{2}{|c|}{$A E_{a K}=$} & \multicolumn{2}{|c|}{2.098} & & & \multicolumn{4}{|c|}{ Ptork $=.395$} & & & \multicolumn{4}{|c|}{$P F_{(\sigma 0)}=.216$} \\
\hline \multicolumn{6}{|c|}{ Statistical Analysis of Data } & \multicolumn{6}{|c|}{ Building: Spliving- } & \multicolumn{6}{|c|}{ |Room: 1 Conditions: Duller. } \\
\hline
\end{tabular}


DECREASE IN ILLUMINATION BY DESK ROWS

ACROSS ROOM \#2, CHESTNUT STREET SCHOOL

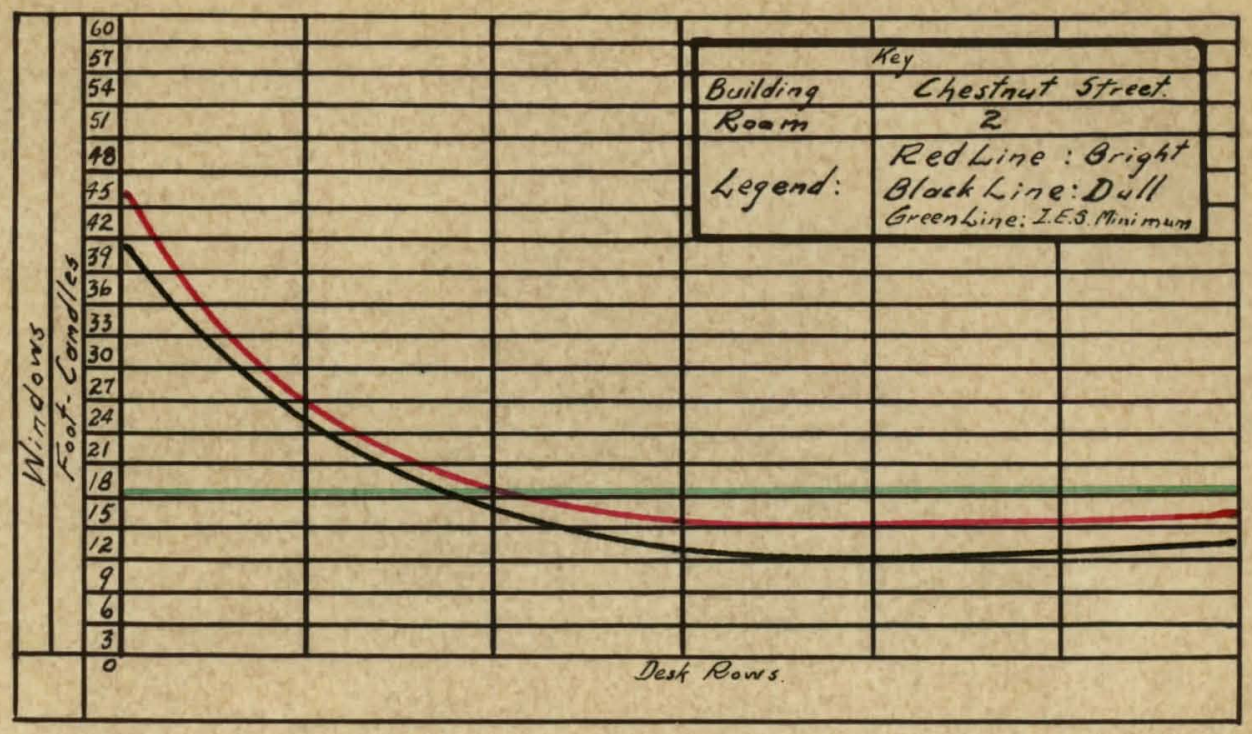

$\frac{\text { FIGURE }}{\text { Illumination Level Distribution Curves }}$

TABLE III

Statistical Data for Curves Mbove

\begin{tabular}{|c|c|c|c|}
\hline & $\begin{array}{l}\text { Mean Illumination } \\
\text { Foot Condles } \\
\text { Desk- Top. }\end{array}$ & $\frac{\text { Voriogbility }}{\sigma_{\text {dist }}=\left(\frac{\sum F D^{2}}{N}-c^{2}\right)^{1 / 2}}$ & $\frac{\text { Peliability }}{P E}=\frac{.6745}{\sqrt{N}}$ \\
\hline \multirow{3}{*}{$\begin{array}{l}0 \\
0 \\
x \\
k \\
a \\
0 \\
0\end{array}$} & 42.89 & 33.06 & 4.37 \\
\hline & 12.35 & 4.56 & .59 \\
\hline & 12.65 & 6.63. & .86 \\
\hline \multirow{3}{*}{$\overbrace{}^{0}$} & 38.75 & 27.43 & 2.67 \\
\hline & 9.67 & 5.86 & .52 \\
\hline & 10.13 & 7.63 & .72 \\
\hline
\end{tabular}


TABLE XI

\begin{tabular}{|c|c|c|c|c|c|c|c|c|c|c|c|c|c|c|c|c|c|}
\hline \multicolumn{6}{|c|}{ Seats Adjacent to Windows } & \multicolumn{6}{|c|}{ Seats of Center } & \multicolumn{6}{|c|}{ Seat's APocent to Oprosits libll } \\
\hline Stop & mid.pt. & $F$ & 0 & $F O$ & $F D^{2}$ & Stop & MidPA. & $F$ & 0 & $F 0$ & $F D^{2}$ & Step & Mit-PT: & $F$ & 0 & $F D$ & $F D^{2}$ \\
\hline $45-150$ & 147.5 & & & & & $29-30$ & 29.5 & & & & & $29-30$ & 29.5 & & & & \\
\hline $140-145$ & 142.5 & 1 & 20 & 20 & 400 & $28-29$ & 28.6 & & & & & $28-29$ & 28.5 & & & & \\
\hline $135-140$ & 137.5 & 0 & 19 & & & $27-28$ & 27.5 & & & & & $27-28$ & 27.5 & I & 15 & 15 & 225 \\
\hline $30-135$ & 132.5 & 0 & 18 & & & $26-27$ & 26.5 & & & & & $26-27$ & 26.5 & 0 & 14 & & \\
\hline $125-130$ & 127.5 & 0 & 17 & & & $25-26$ & $25.5^{-}$ & & & & & $25-26$ & 25.5 & 2 & 13 & 26 & 338 \\
\hline $20-126$ & 122.5 & 1 & 16 & 16 & 256 & $24-25$ & 24.5 & & & & & $24-25$ & 24.5 & 0 & 12 & & \\
\hline $115-120$ & 117.5 & 0 & 15 & & & $23-24$ & 23.5 & & & & & $23-24$ & 23.5 & 0 & II & & \\
\hline $110-115$ & 112.5 & 0 & 14 & & & $22-23$ & 22.5 & 1 & 11 & 11 & 121 & $22-23$ & 22.5 & 0 & 10 & & \\
\hline $105-110$ & 107.5 & 0 & 13 & & & $21-22$ & 21.5 & 0 & 10 & & & $21-22$ & 21.5 & 1 & 9 & 9 & 81 \\
\hline $100-105$ & 102.5 & I & 12 & 12 & 144 & $20-21$ & 20.5 & 7 & 9 & 9 & 81 & $20-21$ & 20.5 & 2 & 8 & 16 & 128 \\
\hline $95 \div 100$ & 97.6 & 0 & 11 & & & $19-20$ & 19.5 & 1 & 8 & 8 & 64 & $19-20$ & 19.5 & 0 & 7 & & \\
\hline $90-95$ & 92.5 & 0 & 10 & & & $18-19$ & 10.5 & 2 & 7 & 14 & 98 & $18-19$ & 18.5 & 0 & 6 & & \\
\hline $85-90$ & 87.5 & 0 & 9 & & & $17-18$ & 12.5 & 0 & 6 & & & $17-18$ & 17.5 & 0 & 5 & & \\
\hline $80-85$ & 82.5 & 1 & 8 & 8 & 64 & $16-17$ & 16.5 & 0 & 5 & & & $16-17$ & 16.5 & 0 & 4 & & \\
\hline $75-80$ & 77.5 & 0 & 7 & & & $15-16$ & 15.5 & 2 & 4 & 8 & 32 & $15-16$ & 15.5 & 2 & 3 & $6+72$ & 18 \\
\hline $70-15$ & 72.5 & 0 & 6 & & & $14-15$ & 14.5 & 1 & 3 & 3 & 9 & $140 / 5$ & 14.5 & 0 & 2 & & \\
\hline $65-70$ & 67.5 & 0 & 5 & & & $13-14$ & 13.5 & 2 & 2 & 4 & 8 & $13-14$ & 13.5 & 0 & 1 & & \\
\hline $60-65$ & 62.5 & 1 & 4 & 5 & 20 & $12-13$ & 12.5 & 3 & 1 & $3+60$ & 3 & $12-13$ & 12.5 & 4 & 0 & 0 & 0 \\
\hline $55-60$ & 57.5 & 0 & 3 & & & $11-12$ & 11.5 & 2 & 0 & 0 & 0 & $11-12$ & 11.5 & 1 & -1 & -1 & 1 \\
\hline $50-55$ & 52.5 & 0 & 2 & & & $10-11$ & 10.5 & 5 & -1 & -5 & 5 & $10-11$ & 10.5 & 4 & -2 & -8 & 16 \\
\hline $15-50$ & 47.5 & 2 & 1 & $2+63$ & 2 & $9-10$ & 9.5 & 1 & -2 & -2 & 4 & $9-10$ & 9.5 & 7 & -3 & -3 & 9 \\
\hline 50.45 & 42.5 & 2 & 0 & 0 & 0 & $8-9$ & 8.5 & 1 & -3 & -3 & 9 & $8-9$ & 8.5 & 2 & -4 & -8 & 32 \\
\hline 3540 & 37.5 & 2 & -1 & -2 & 2 & $7-8$ & 7.5 & 0 & -4 & & & $7-8$ & 7.5 & 0 & -5 & & \\
\hline $30-35$ & 32.5 & 1 & -2 & -2 & 4 & $6-7$ & 6.5 & 3 & -5 & -15 & 75 & $6-7$ & 6.5 & 4 & -6 & -24 & 144 \\
\hline 2530 & 27.5 & 5 & -3 & -15 & 45 & $5-6$ & 5.5 & 2 & -6 & $-12-37$ & 72 & $5-6$ & 5.5 & 1 & -7 & -7 & 49 \\
\hline $20-25$ & 22.5 & 4 & -4 & -16 & 64 & $4-5$ & 4.5 & & & & & $4-5$ & 4.5 & 1 & -8 & -8 & 64 \\
\hline $15-20$ & 17.5 & 4 & -5 & -20 & 100 & $3-4$ & 3.5 & & & & & $3-4$ & 3.5 & I & -9 & $-9-68$ & 81 \\
\hline $10-15$ & 12.5 & 1 & -6 & $-6-61$ & 36 & $2-3$ & 2.5 & & & & & $2-3$ & 2.5 & & & & \\
\hline $5-10$ & 7.5 & & & & & $1-2$ & 1.5 & & & & & $1-2$ & 1.5 & & & & \\
\hline $0-5$ & 2.5 & & & & & $0-1$ & 0.5 & & & & & $0-1$ & 0.5 & & & & \\
\hline \multicolumn{2}{|c|}{$c=.077$} & 26 & & +2 & $1 / 37$ & \multicolumn{2}{|c|}{$c=.85 \%$} & 27 & & +23 & 581 & \multicolumn{2}{|c|}{$c=.148$} & 27 & & +4 & 1186 \\
\hline \multirow{2}{*}{\multicolumn{2}{|c|}{$\begin{array}{l}c^{2}=.0059 \\
C=.385\end{array}$}} & \multicolumn{2}{|c|}{$A_{v \text { dist. }}=42.89$} & \multicolumn{2}{|c|}{$\sigma_{\text {dist }}=33.06$} & $c^{2}=$ & -.724 & \multicolumn{2}{|c|}{$A r_{\text {dist }}=12.35$} & \multicolumn{2}{|c|}{$\sigma_{\text {dist }}=4.56$} & $c^{2}=$ & $=.022$ & \multicolumn{2}{|c|}{ Ar. dist $=12.65$} & \multicolumn{2}{|c|}{$\sigma_{\text {dist: }}=6.63$} \\
\hline & & \multicolumn{4}{|c|}{$P E_{\text {or. }}=4.37$} & & & \multicolumn{4}{|c|}{$P E_{\text {ar }}=.592$} & & & \multicolumn{4}{|c|}{$P E($ ar $)=.860$} \\
\hline
\end{tabular}


TABLE XII

\begin{tabular}{|c|c|c|c|c|c|c|c|c|c|c|c|c|c|c|c|c|c|}
\hline \multicolumn{6}{|c|}{ Windows } & \multicolumn{6}{|c|}{ Seats of Center } & \multicolumn{6}{|c|}{ Seats Alfocent to Opposite Wloll } \\
\hline Stop & Mid.p. & $F$ & 0 & Fo & $F D^{2}$ & Stop & Miater. & $F$ & 0 & $F 0$ & $F D^{2}$ & Step & Mid-AT & $F$ & 0 & $F D$ & $F D^{2}$ \\
\hline $195-150$ & 147.5 & & & & & $29-30$ & 29.5 & & & & & $29-30$ & 29.5 & 3 & 20 & 60 & 1200 \\
\hline $140-145$ & 142.5 & & & & & $28-29$ & 28.6 & & & \multirow{3}{*}{19} & \multirow{3}{*}{$36 /$} & $28-29$ & $2 B, 5$ & 0 & 19 & & \multirow{2}{*}{1200} \\
\hline $135-140$ & 137.5 & & & & & $27-28$ & 27.5 & 1 & 19 & & & $27-28$ & 27.5 & 0 & 18 & & \\
\hline $130-135$ & 132.5 & & & & & $26-27$ & 26.5 & 0 & 18 & & & $26-27$ & 26.5 & 0 & 17 & & \multirow{2}{*}{$5 / 2$} \\
\hline $125-130$ & 127.5 & & & & & $25-26$ & 25.5 & 0 & 17 & & & $25-26$ & 25.5 & 2 & 16 & 32 & \\
\hline $120-126$ & 122.5 & 1 & 18 & 18 & 324 & $24-25$ & 24.5 & 0 & 16 & \multirow{2}{*}{15} & & $24-25$ & 24.5 & 0 & 15 & & \multirow{2}{*}{\begin{tabular}{|l} 
\\
\end{tabular}} \\
\hline $115-120$ & 117.5 & 0 & 17 & & & $23-24$ & 23.5 & 1 & 15 & & 225 & $23-24$ & 23.5 & 0 & 14 & & \\
\hline $110-115$ & 112.5 & 0 & 16 & & & $22-23$ & 22.5 & 1 & 14 & \multirow[t]{2}{*}{14} & 196 & $22-23$ & 22.5 & 0 & 13 & & \multirow{2}{*}{288} \\
\hline $105-110$ & 107.5 & 0 & 15 & & & $21-22$ & 21.5 & 0 & 13 & & & $21-22$ & 21.5 & 2 & 12 & 24 & \\
\hline $100-105$ & 102.5 & 2 & 14 & 28 & 392 & $20-21$ & 20.5 & 1 & 12 & 12 & 144 & $20-21$ & 20.5 & 0 & /I & & \\
\hline $95 \div 100$ & 97.5 & 0 & 13 & & & $19-20$ & 195 & 2 & II & 22 & 242 & $19-20$ & 19.5 & 0 & 10 & & \\
\hline $90-95$ & 92.5 & 0 & 12 & & & $18-19$ & 10.5 & 0 & 10 & & & $18-19$ & 18.5 & 2 & 9 & 18 & \multirow{2}{*}{162} \\
\hline $85-90$ & 87.5 & 1 & 11 & 11 & 121 & $17-18$ & 17.5 & 0 & 9 & \multirow[b]{2}{*}{24} & & $17-18$ & 17.5 & 0 & 8 & & \\
\hline $80-85$ & 82.5 & 3 & 10 & 30 & 300 & $16-17$ & 16.5 & 3 & 8 & & 192 & $16-17$ & 16.5 & 0 & 7 & & 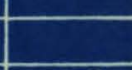 \\
\hline $75-80$ & 72.5 & 0 & 9 & & & $15-16$ & 15.5 & 3 & 7 & \multirow{2}{*}{$\begin{array}{r}21 \\
6\end{array}$} & 147 & $15-16$ & 15.5 & 2 & 6 & 12 & \multirow{2}{*}{$\frac{72}{25}$} \\
\hline $70-75$ & 72.5 & 2 & 8 & 16 & 128 & $14-15$ & 14.5 & 1 & 6 & & 36 & $14-9 / 5$ & 14.5 & 7 & 5 & 5 & \\
\hline $65-70$ & 67.5 & 0 & 1 & & & $13-14$ & 13.5 & 1 & 5 & \multirow{2}{*}{$\begin{array}{c}5 \\
12 \\
\end{array}$} & 25 & $13-14$ & 13.5 & 1 & 4 & 4 & \multirow{2}{*}{$\frac{16}{9}$} \\
\hline $60-65$ & 62.5 & 1 & 6 & 6 & 36 & $12-13$ & 12.5 & 3 & 4 & & 48 & $12-13$ & 12.5 & 1 & 3 & 3 & \\
\hline $55-60$ & 57.5 & 0 & 5 & & & $11-12$ & 11.5 & 1 & 3 & 3 & 9 & $11-12$ & 11.5 & 0 & 2 & & \multirow{2}{*}{4} \\
\hline $50-555$ & 52.5 & 0 & 4 & & & $10-11$ & 10.5 & 4 & 2 & 8 & 16 & $10-11$ & 10.5 & 4 & 1 & $4^{+162}$ & \\
\hline $15-50$ & 47.5 & 2 & 3 & 6 & 18 & $9-10$ & 9.5 & 4 & 1 & $4+165$ & 4 & $9-10$ & 9.5 & 2 & 0 & 0 & 0 \\
\hline$\$ 0.45$ & 42.5 & 2 & 2 & 4 & 8 & $8-9$ & 8.5 & 7 & 6 & 0 & 0 & $8-9$ & 8.5 & 6 & -1 & -6 & 6 \\
\hline 3540 & 37.5 & 3 & 1 & $3+122$ & 3 & $7-8$ & 7.5 & 1 & -1 & -1 & 7 & $7-8$ & 7.5 & 3 & -2 & -6 & 12 \\
\hline $30-35$ & 32.5 & 6 & 0 & 0 & 0 & $6-7$ & 6.5 & 2 & -2 & -4 & 8 & $6-7$ & 6.5 & 3 & -3 & -9 & 27 \\
\hline $25=30$ & 27.5 & 6 & -1 & -6 & 6 & $5-6$ & 5.5 & 9 & -3 & -27 & 81 & $5-6$ & 5.5 & 5 & -4 & -20 & 80 \\
\hline $20-25$ & 22.5 & 9 & -2 & -18 & 36 & $4-5$ & 4.5 & 4 & -4 & -16 & 64 & $4-5$ & 4.5 & 3 & -5 & -15 & 75 \\
\hline $15-20$ & 17.5 & 3 & -3 & -9 & 27 & $3-4$ & 3.5 & 5 & -5 & -25 & 125 & $3-4$ & 3.5 & 3 & -6 & -18 & 108 \\
\hline $10-15$ & 12.5 & 6 & -4 & -24 & 96 & $2-3$ & 2.5 & 4 & -6 & $-24-97$ & 144 & $2-3$ & 2.5 & 8 & -7 & $-56-130$ & 392 \\
\hline $5-10$ & 7.5 & 1 & -5 & $-5-62$ & 25 & $1-2$ & 1.5 & & & & & $1-2$ & 1.5 & & & & \\
\hline $0-5$ & 2.5 & & & & & $0-1$ & 0.5 & & & & & $0-1$ & 0.5 & & & & \\
\hline$c=$ & 1.25 & 48 & & +60 & 1520 & c & $=1.17$ & 58 & & +68 & 2068 & & $=.627$ & 51 & & +32 & 2968 \\
\hline $\begin{array}{l}C^{2}= \\
C=\end{array}$ & $\frac{1.563}{6.25}$ & Ay.dis & $=38.75$ & $\sigma_{\text {dist }}=$ & $=27.43$ & $c^{2}=$ & $=1.37$ & $A V_{\text {dist. }}$ & $=9.67$ & $\sigma_{\text {dist. }}$ & $=5.86$ & $c^{2}=$ & $=.393$ & $A_{r . a}$ & $t=10.13$ & $\sigma_{\text {dist }}$ & $=7.63$ \\
\hline & & & $F_{\text {or }}=$ & 2.671 & & & & & $O F_{\alpha v}=$ & .5186 & & & & & $E_{a r}=$ & .724 & \\
\hline Sta: & fistic & S & nalysi & is of & Data & & & & Build, & ing: ch & & Poc & on: $\mathbb{Z}$ & & anditio & ns: & oullowd \\
\hline
\end{tabular}




\section{DECREASE IN ILLUMINATION BY DESK ROWS} ACROSS ROOM \#3,ROSE HILL SCHOOL

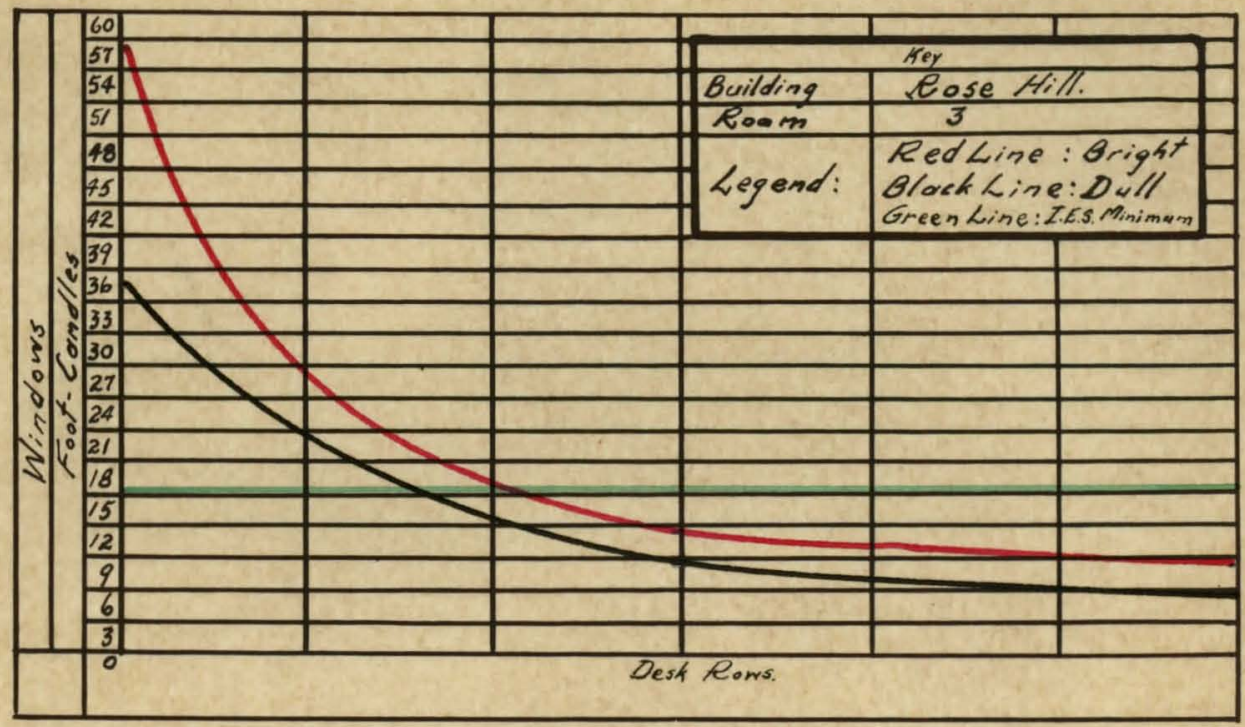

FIGURE 25

Illumination Level Drstribution Cunves

THBLE III

Statistical Data for Curves Above

\begin{tabular}{|c|c|c|c|}
\hline & $\begin{array}{c}\text { Mean Illumination } \\
\text { Foot: Korndles } \\
\text { Dost-Top. }\end{array}$ & $\frac{\text { Variability }}{\sigma_{\text {dist }}=\left(\frac{\xi F D^{2}}{N}-c^{2}\right)^{1 / 2}}$ & $\begin{array}{l}E_{e} \text { liability } \\
P E_{\text {av }}=\frac{6745}{\sqrt{N}}(\text { (dist) }\end{array}$ \\
\hline \multirow{3}{*}{$\begin{array}{l}0^{3} \\
x \\
5 \\
a \\
0^{1}\end{array}$} & 56.64 & 23.59 & 2.69 \\
\hline & 11.61 & 4.33 & 49 \\
\hline & 8.06 & 3.85 & .41 \\
\hline \multirow{3}{*}{$\begin{array}{l}0^{5} \\
0^{2} \\
0^{2}\end{array}$} & 34.50 & 18.29 & 2.25 \\
\hline & 8.67 & 4.27 & .48 \\
\hline & 5.98 & 4.56 & 62 \\
\hline
\end{tabular}


TRBLE XUL

\begin{tabular}{|c|c|c|c|c|c|c|c|c|c|c|c|c|c|c|c|c|c|}
\hline \multicolumn{6}{|c|}{ Windows } & \multicolumn{6}{|c|}{ Seats of Center } & \multicolumn{6}{|c|}{ Seats Hijocent to Opoosite Moll } \\
\hline Step & mid.pt. & $F$ & 0 & $F D$ & $F D^{2}$ & stop & MideA & $F$ & 0 & $F 0$ & $F D^{2}$ & Step & M.d.AT & $F$ & 0 & $F$ & $F D^{2}$ \\
\hline $45+50$ & 147.5 & & & & & $29-30$ & 29.5 & & & & & $29-30$ & 29.5 & & & & \\
\hline $140-145$ & 142. 5 & & & & & $28-29$ & 28.6 & & & & & $28-24$ & 28.5 & & & & \\
\hline $135-140$ & 137.5 & & & & & $27-28$ & 27.5 & & & & & $27-28$ & 27.5 & & & & \\
\hline $30-135$ & 132.5 & & & & & $26-27$ & 26.5 & & & & & $26-27$ & $26.5^{\circ}$ & & & & \\
\hline $25-130$ & 127,5 & & & & & $25-26$ & $25.5^{\circ}$ & & & & & $25-26$ & 25.5 & & & & \\
\hline $20-125$ & 122.5 & & & & & $24-25$ & 24.5 & & & & & $24-25$ & 24.5 & & & & \\
\hline $115-120$ & 117.5 & & & & & $23-24$ & 23.5 & & & & & $23-24$ & 23.5 & & & & \\
\hline $110-115$ & 112.5 & & & & & $22-23$ & 22.5 & & & & & $22-23$ & 22.5 & & & & \\
\hline $105-110$ & 107.5 & & & & & $21-22$ & 21.5 & 1 & 10 & 10 & 100 & $2 /-22$ & 21.5 & & & & \\
\hline $100-105$ & 102.5 & 2 & 10 & 20 & 200 & $20-21$ & 20.5 & 1 & 9 & 9 & 81 & $20-21$ & 20.5 & 1 & 13 & 13 & 169 \\
\hline $95 \div 100$ & 97.5 & 1 & 9 & 9 & 81 & $19-20$ & 195 & & 8 & & & $19-20$ & 19.5 & & 12 & & \\
\hline $90-95$ & 92.5 & 7 & 8 & 8 & 64 & $18-19$ & 16.5 & 1 & 7 & 7 & 49 & $18-19$ & 18.5 & 1 & II & 11 & 121 \\
\hline $85-90$ & 87.5 & 7 & 7 & 7 & 49 & $17-18$ & 17.5 & 1 & 6 & 6 & 36 & $17-18$ & 17.5 & & 10 & & \\
\hline $80-85$ & 82.5 & 3 & 6 & 18 & 108 & $16-17$ & 16.5 & 2 & 5 & 10 & 50 & $16-17$ & 16.5 & 1 & 9 & 9 & 81 \\
\hline $75-80$ & 775 & & 5 & & & $15-16$ & 15.5 & 7 & 4 & 4 & 16 & $15-16$ & 15.5 & & 8 & & \\
\hline $70-75$ & 72.5 & 1 & 4 & 4 & 16 & $14-15$ & 14.5 & 1 & 3 & 3 & 9 & $140 / 5$ & 14.5 & & 7 & & \\
\hline $65-70$ & 67.5 & 1 & 3 & 3 & 9 & $3-14$ & 13.5 & 2 & 2 & 4 & 8 & $13-14$ & 13.5 & 1 & 6 & 6 & 36 \\
\hline $60-65$ & 62.5 & 3 & 2 & 6 & 12 & $12-13$ & 12.5 & 4 & 1 & $4 \times 57$ & 4 & $12-13$ & 12.5 & 1 & 5 & 5 & 25 \\
\hline $55-60$ & 57.5 & 5 & 1 & $5+80$ & 5 & $11-12$ & 11.5 & 8 & 0 & 0 & 0 & $11-12$ & 11.5 & 1 & 4 & 4 & 16 \\
\hline $50-5,5$ & 52.5 & 4 & 0 & 0 & 0 & $10-11$ & 10.5 & 3 & -1 & -3 & 3 & $10-11$ & 10.5 & 2 & 3 & 6 & 18 \\
\hline $15-50$ & 47.5 & 2 & -1 & -2 & 2 & $9-10$ & 9.5 & 2 & -2 & -4 & 8 & $9-10$ & 9.5 & 3 & 2 & 6 & 12 \\
\hline 40.45 & 42.5 & 2 & -2 & -4 & 8 & $8-9$ & 8.5 & 2 & -3 & -6 & 18 & $8-9$ & 8.5 & 8 & 1 & $8+68$ & 8 \\
\hline 3540 & 375 & 2 & -3 & -6 & 18 & $7-8$ & 7.5 & & -4 & & & $7-8$ & 7.5 & 4 & 0 & 0 & 0 \\
\hline $30-35$ & 32.5 & 2 & -4 & -8 & 32 & $6-7$ & 6.5 & 1 & -5 & -5 & 25 & $6-7$ & 6.5 & 4 & -1 & -4 & 4 \\
\hline 2530 & 27.5 & 2 & -5 & -10 & 50 & $5-6$ & 5.5 & 2 & -6 & -12 & 72 & $5-6$ & 5.5 & 5 & -2 & -10 & 20 \\
\hline $20-25$ & 22.5 & 1 & -6 & -6 & 36 & $4-5$ & 4.5 & 1 & -7 & -7 & 49 & $4-5$ & 4.5 & 6 & -3 & -18 & 54 \\
\hline $15-20$ & 17.5 & 1 & -7 & -7 & 49 & $3-4$ & 3.5 & 2 & -8 & $-16-53$ & 128 & $3-4$ & 3.5 & 2 & -4 & -8 & 32 \\
\hline $10-15$ & 12.5 & 1 & -8 & $-8-51$ & 64 & $2-3$ & 2.5 & & & & & $2-3$ & 2.5 & 1 & -5 & $-5=45$ & 25 \\
\hline $5-10$ & 7.5 & & & & & $1-2$ & 1.5 & & & & & $1-2$ & 1.5 & & & & \\
\hline $0-5$ & 2.5 & & & & & $0-1$ & 0.5 & & & & & $0-1$ & 0.5 & & & & \\
\hline$c=$ & .828 & 35 & & +29 & 803 & \multicolumn{2}{|c|}{$c=.11 A$} & 35 & & +4 & 656 & \multicolumn{2}{|c|}{$c=.561$} & 41 & & +23 & 621 \\
\hline \multirow{2}{*}{\multicolumn{2}{|c|}{$\begin{aligned} c^{2} & =.686 \\
C^{2} & =4.14\end{aligned}$}} & \multicolumn{2}{|c|}{ Ar. dist $=56.64$} & \multicolumn{2}{|c|}{$\sigma_{\text {dist. }}=23.59$} & $c^{2}=$ & $=.013$ & \multicolumn{2}{|c|}{ Av. dist. $=11.61$} & \multicolumn{2}{|c|}{$\sigma_{\text {dist }}=4.33$} & $c^{2}=$ & $=.315$ & \multicolumn{2}{|c|}{$A V_{\text {dist. }}=8.06$} & \multicolumn{2}{|c|}{$\sigma_{\text {dist. }}=3.85$} \\
\hline & & \multicolumn{4}{|c|}{$P E_{\alpha K}=2.69$} & & & \multicolumn{4}{|c|}{$P E_{a v}=.493$} & & & \multicolumn{4}{|c|}{$P_{\text {or }}=.406$} \\
\hline \multicolumn{6}{|c|}{ Statistical Analysis of Data } & \multicolumn{6}{|c|}{ Building: Dose Hill } & Roc & om: 3 & \multicolumn{4}{|c|}{ Conditions: Bright. } \\
\hline
\end{tabular}


TABLE 2QV

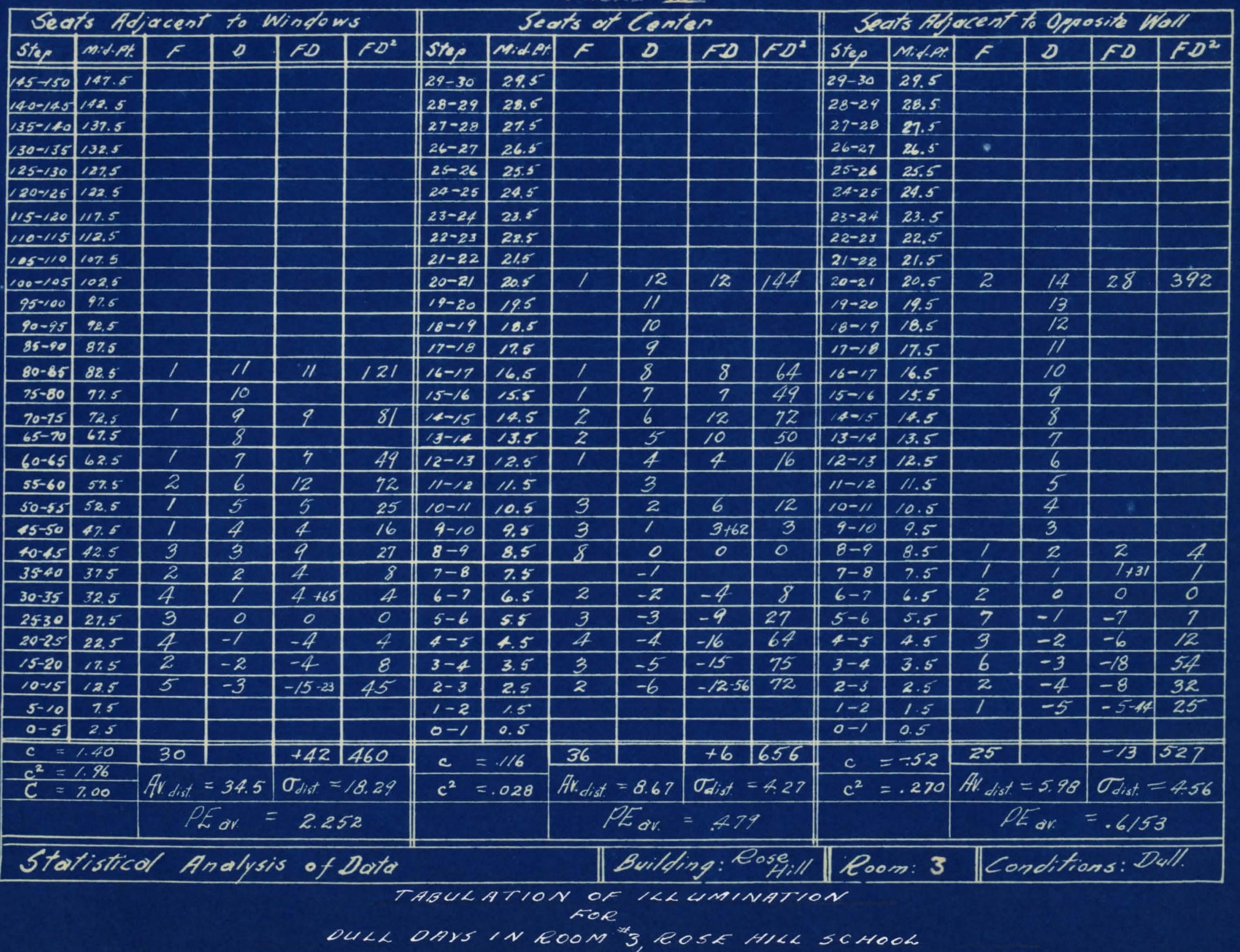


DECREASE IN ILIUNINATION BY DESK ROWS ACROSS ROOM \#4, PORT FULTON SCHOOL

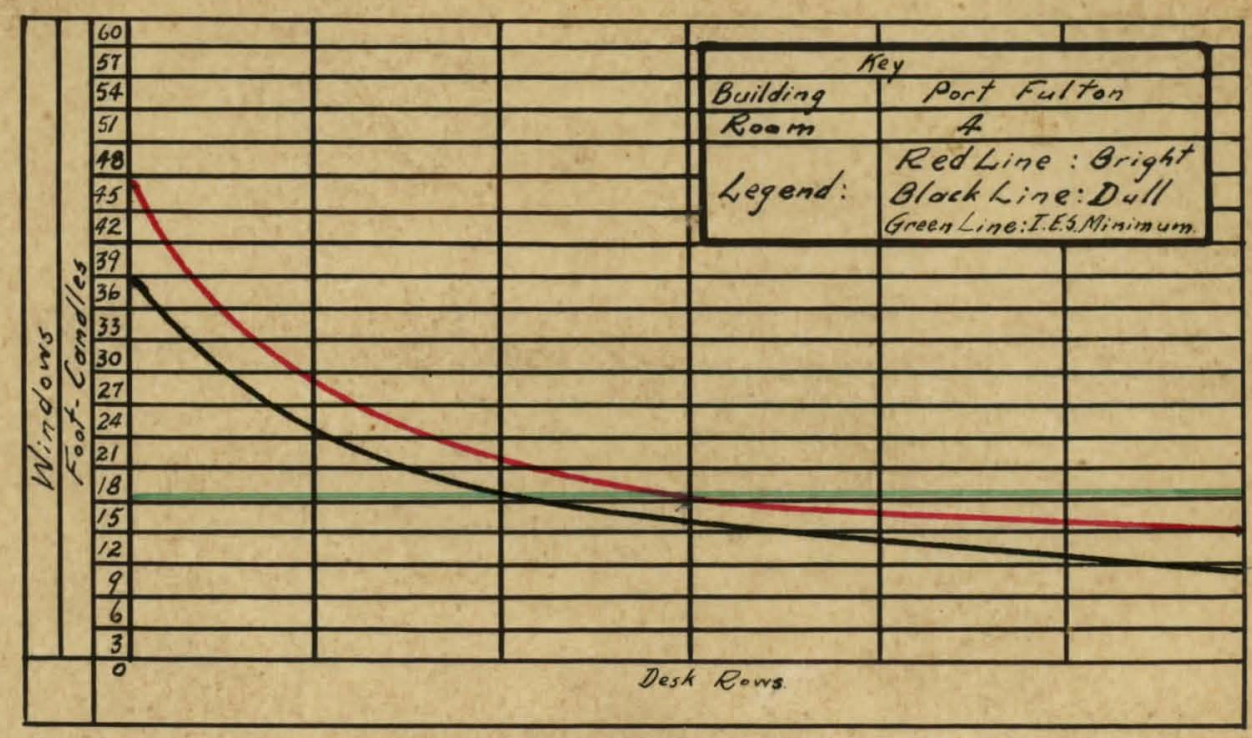

FIGURE 26

Illumination Level Distribution Curves

$$
\text { TABLE II }
$$

Statistical Date for Lurves Above

\begin{tabular}{|c|c|c|c|}
\hline & $\begin{array}{l}\text { Mean Illumination } \\
\text { Foot Kondles } \\
\text { Dosk- Top. }\end{array}$ & $\frac{\text { Variability }}{\sigma_{\text {dist. }}=\left(\frac{\sum F D^{2} c^{2}}{N}\right)^{1 / 2}}$ & $\frac{e_{e l i a b i l i t y}}{P E_{a v}=\frac{.6745}{\sqrt{N}}\left(d_{i s t}\right)}$ \\
\hline \multirow{3}{*}{$\begin{array}{l}0 \\
0^{0} \\
\frac{1}{2} \\
a^{2} \\
0^{1}\end{array}$} & 44.30 & 17.54 & 2.37 \\
\hline & 14.80 & 4.65 & .55 \\
\hline & 11.83 & 3.77 & .46 \\
\hline \multirow{3}{*}{$\begin{array}{c}0 \\
0 \\
0\end{array}$} & 34.91 & 17.92 & 2.33 \\
\hline & 12.90 & 6.16 & .76 \\
\hline & 8.02 & 3.60 & .44 \\
\hline
\end{tabular}


TABLE XI

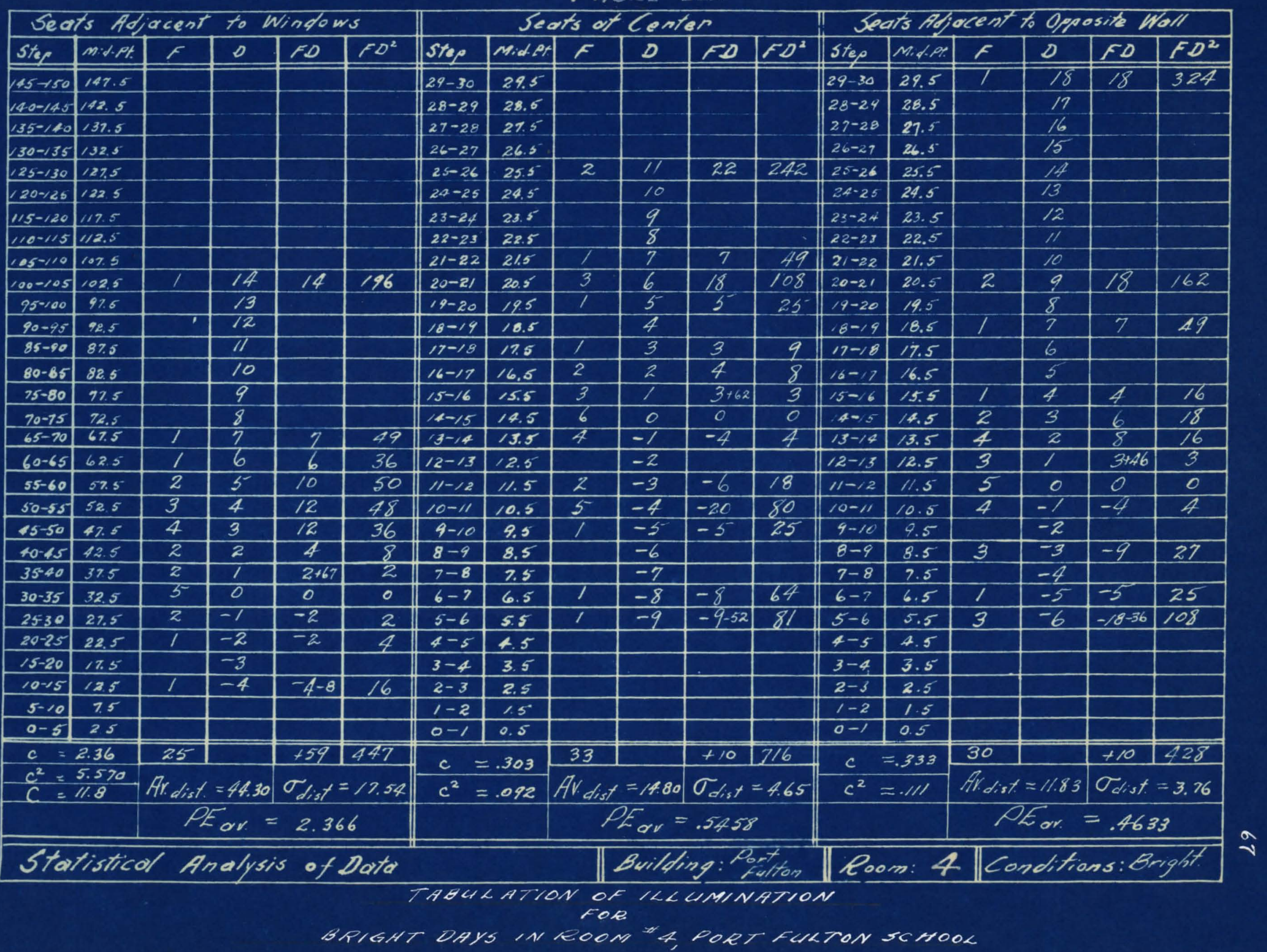


THQLE TVL

\begin{tabular}{|c|c|c|c|c|c|c|c|c|c|c|c|c|c|c|c|c|c|}
\hline \multicolumn{6}{|c|}{ Seats Adjacent to Windows } & \multicolumn{6}{|c|}{ Seats of Center } & \multicolumn{6}{|c|}{ Seats Afjocent to Opposite lloll } \\
\hline Step & m.d.P. & $F$ & 0 & $F D$ & $F D^{2}$ & stop & MideA. & $F$ & $D$ & $F 0$ & $F D^{2}$ & Step & Maf-Pt: & $F$ & 0 & $F D$ & $F D^{2}$ \\
\hline $45-150$ & 147.5 & & & & & $29-30$ & 29.5 & & & & & $29-30$ & 29.5 & 7 & 22 & 22 & 484 \\
\hline $140-145$ & 142.5 & & & & & $28-29$ & 28.5 & & & & & $28-24$ & 28.5 & & 21 & & \\
\hline $135-140$ & 137.5 & & & & & $27-28$ & 27.5 & & & & & $27-28$ & 27.5 & & 20 & & \\
\hline$(30-135)$ & 132.5 & & & & & $26-27$ & 26.5 & & & & & $26-27$ & $26.5^{\circ}$ & & 19 & & \\
\hline $25-130$ & 127.5 & & & & & $25-26$ & $25.5^{\circ}$ & 3 & 13 & 39 & & $25-26$ & 25.5 & & 18 & & \\
\hline $20-126$ & 122.5 & & & & & $24-25$ & 24.5 & & 12 & & & $24-25$ & $24.5^{-}$ & & 17 & & \\
\hline $115-120$ & 117.5 & & & & & $23-24$ & 23.5 & 1 & 11 & II & 121 & $23-24$ & 23.5 & & 16 & & \\
\hline $110-115$ & $112.5^{\circ}$ & & & & & $22-23$ & 22.5 & 2 & 10 & 20 & 200 & $22-23$ & 22.5 & & 15 & & \\
\hline $105-110$ & 107.5 & & & & & $21-22$ & 21.5 & & 9 & & & $21-22$ & 21.5 & & 14 & & \\
\hline $100-105$ & 102.5 & & & & & $20-21$ & 20.5 & 2 & 8 & 16 & 108 & $20-21$ & 20.5 & & 13 & & \\
\hline $95 \div 00$ & 97.5 & & & & & $19-20$ & 19.5 & & 7 & & & $19-20$ & 19.5 & & 12 & & \\
\hline $90-95$ & 92.5 & & & & & $18-19$ & 10.5 & & 6 & & & $18-19$ & 18.5 & & II & & \\
\hline $85-90$ & 87.5 & & & & & $17-18$ & 17.5 & & 5 & & & $17-18$ & 17.5 & & 10 & & \\
\hline $80-85$ & 82.5 & 1 & 9 & 9 & 81 & $16-17$ & 16.5 & & 4 & & & $16-17$ & 16.5 & & 9 & & \\
\hline $75-80$ & 77.5 & & 8 & & & $15-16$ & 15.5 & 3 & 3 & 9 & 27 & $15-16$ & 15.5 & 1 & 8 & 8 & 64 \\
\hline $70-75$ & 72.5 & 1 & 7 & 7 & 49 & $14-15$ & 14.5 & 1 & 2 & 2 & 4 & $14-15$ & 14.5 & & 7 & & \\
\hline $65-70$ & 67.5 & & 6 & & & $13-14$ & 13.5 & 1 & 7 & $1+98$ & 7 & $13-14$ & 13.5 & & 6 & & \\
\hline $60-65$ & 62.5 & 1 & 5 & 5 & 25 & $12-13$ & 12.5 & 4 & 0 & 0 & 0 & $12-13$ & 12.5 & 3 & 5 & 15 & 75 \\
\hline $55-60$ & 52.5 & & 4 & & & $11-12$ & 11.5 & 1 & -1 & -1 & 1 & $11-12$ & 11.5 & 3 & 4 & 12 & 48 \\
\hline $50-535$ & 52.5 & 1 & 3 & 3 & 9 & $10-11$ & 10.5 & 1 & -2 & -2 & 4 & $10-11$ & 10.5 & 2 & 3 & 6 & 18 \\
\hline $45-50$ & 47.5 & 2 & 2 & 4 & 8 & $9-10$ & 9,5 & 1 & -3 & -3 & 9 & $9-10$ & 9.5 & & 2 & & \\
\hline 70.45 & 42.5 & 3 & 1 & $3+31$ & 3 & $8-9$ & 8.5 & & -4 & & & $8-9$ & 8.5 & 3 & 1 & $3+66$ & 3 \\
\hline $35-40$ & 37.5 & 4 & 0 & 0 & 0 & $7--8$ & 7.5 & 1 & -5 & -5 & 25 & $7-8$ & 7.5 & 3 & 0 & 0 & 0 \\
\hline $30-35$ & 32.5 & 3 & -1 & -3 & 3 & $6-7$ & 6.5 & & -6 & & & $6-7$ & 6.5 & 2 & -1 & -2 & 2 \\
\hline $25=30$ & 27.5 & 2 & -2 & -4 & 8 & $5-6$ & 5.5 & 4 & -7 & -28 & 196 & $5-6$ & 5.5 & 4 & -2 & -8 & 16 \\
\hline $20-25$ & 22.5 & 3 & -3 & -9 & 27 & $4-5$ & 4.5 & 1 & -8 & -8 & 64 & $4-5$ & 4.5 & 2 & -3 & -6 & 18 \\
\hline $15-20$ & 17.5 & 1 & -4 & -4 & 16 & $3-4$ & 3.5 & 2 & -9 & -18 & 162 & $3-4$ & 3.5 & 1 & -4 & -4 & 16 \\
\hline $10-15$ & 12.5 & 5 & $-5-$ & $-25-45$ & 125 & $2-3$ & 2.5 & 1 & -10 & -10 & 100 & $2-3$ & 2.5 & 6 & -5 & $-30-50$ & 150 \\
\hline $5-10$ & 75 & & & & & $1-2$ & 1.5 & 1 & -11 & $-11-86$ & 121 & $1-2$ & 1.5 & & & & \\
\hline $0-5$ & 2.5 & & & & & $0-1$ & 0.5 & & & & & $a-1$ & 0.5 & & & & \\
\hline$c=$ & -.518 & 27 & 1 & -14 & 354 & \multicolumn{2}{|c|}{$c=.4$} & 30 & & +12 & $1 / 43$ & \multirow{2}{*}{\multicolumn{2}{|c|}{$\begin{array}{l}c=.5 / 6 \\
c^{2}=.266\end{array}$}} & 31 & & +16 & 410 \\
\hline \multirow{2}{*}{\multicolumn{2}{|c|}{$C=-2.59$}} & \multicolumn{2}{|c|}{$A r \cdot$ dist. $=34.91$} & \multicolumn{2}{|c|}{$\sigma_{\text {dist. }}=17.92$} & $c^{2}=$ & $=.16$ & \multicolumn{2}{|c|}{$A r_{\text {dist. }}=12.90$} & \multicolumn{2}{|c|}{$\sigma_{\text {dist. }}=6.16$} & & & \multicolumn{2}{|c|}{ Ar. dist $=8.02$} & \multicolumn{2}{|c|}{$\sigma_{\text {dist: }}=3.60$} \\
\hline & & \multicolumn{2}{|c|}{ PE $a v=$} & \multicolumn{2}{|c|}{2.326} & & & \multicolumn{4}{|c|}{$P_{\text {or }}=.7585$} & & & \multicolumn{4}{|c|}{$P E_{\text {ov }}=.4361$} \\
\hline \multicolumn{6}{|c|}{ Statistical Analysis } & \multicolumn{6}{|c|}{ Building: Part Fultom } & \multicolumn{2}{|c|}{ Room: 8} & \multicolumn{4}{|c|}{ Conditions: Dall. } \\
\hline
\end{tabular}




\section{DECREASE IN ILLUMTNATION BY DESK ROVIS ACROSS ROON \#5, INGRAMVILIE SCHOOL}

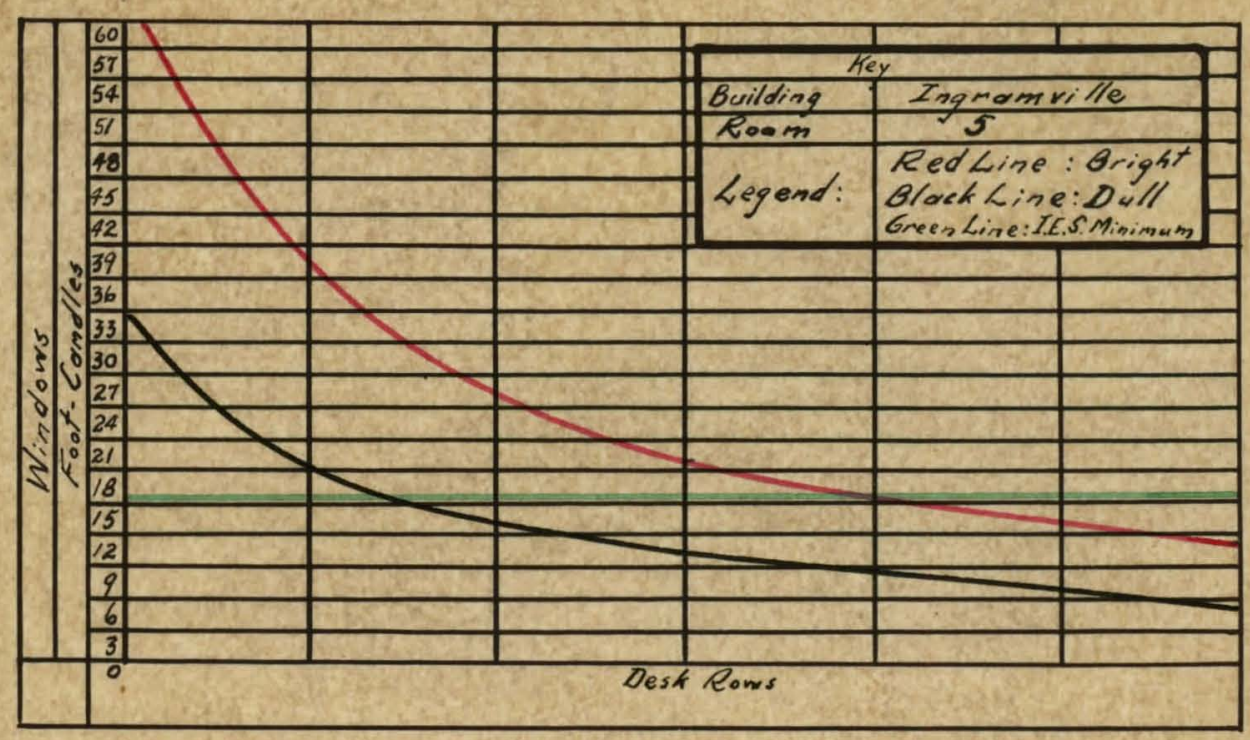

FIGURE 27

Illumination Level Distribution Cunves

THBLE III

Statistical Data for Curves Above

\begin{tabular}{|c|c|c|c|}
\hline & $\begin{array}{c}\text { Mean Illumination } \\
\text { Foot Loondles } \\
\text { Dosk- Top. }\end{array}$ & $\begin{array}{l}\text { Variability } \\
\sigma_{\text {dist }}=\left(\frac{\sum F D^{2}}{N}-c^{2}\right)^{1 / 2}\end{array}$ & $\frac{E_{e} \text { liability }}{\rho E_{\text {av }}=\frac{6745}{\sqrt{N}}(\text { (dist) }}$ \\
\hline \multirow{3}{*}{$\begin{array}{l}0^{0} \\
x^{2} \\
y^{2} \\
0^{1} \\
0^{2}\end{array}$} & 64.25 & 35.71 & 3.67 \\
\hline & 19.05 & 7.12 & .76 \\
\hline & 11.08 & 6.71 & 19 \\
\hline \multirow{3}{*}{ ठ) } & 32.64 & 12.60 & 1.39 \\
\hline & 10.11 & 4.28 & 48 \\
\hline & 5.38 & 2.60 & 30 \\
\hline
\end{tabular}


TAQRE XVII

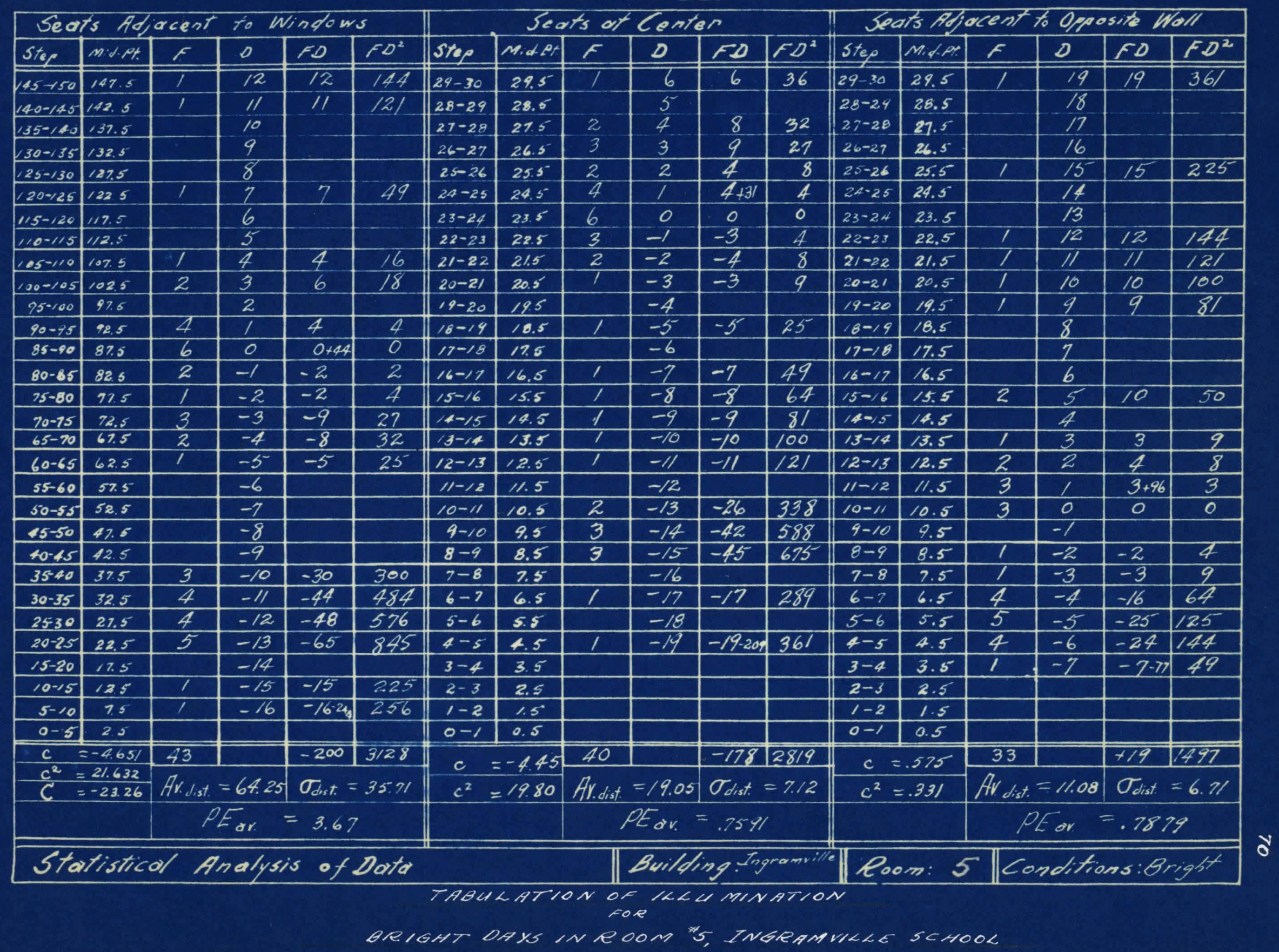


TABLE XVII

\begin{tabular}{|c|c|c|c|c|c|c|c|c|c|c|c|c|c|c|c|c|c|}
\hline \multicolumn{6}{|c|}{ Seats Adjacent to Windows } & \multicolumn{6}{|c|}{ Seat's of Center } & \multicolumn{6}{|c|}{ Seats Alfocent to Opposite Woll } \\
\hline Step & mid.pt. & $F$ & 0 & FO & $F D^{2}$ & Stop & Midet. & $F$ & 0 & Fe & $F D^{2}$ & Step & Mid.Pr & $F$ & 0 & $F D$ & $F D^{2}$ \\
\hline $145-150$ & 147.5 & & & & & $29-30$ & 29.5 & & & & & $29-30$ & 29.5 & & & & \\
\hline $140-145$ & 142.5 & & & & & $28-29$ & $28.5^{6}$ & & & & & $28-29$ & 28.5 & & & & \\
\hline $135-110$ & 137.5 & & & & & $27-28$ & 27.5 & & & & & $27-28$ & 27.5 & & & & \\
\hline $130-135$ & 132.5 & & & & & $26-27$ & 26.5 & & & & & $26-27$ & 26.5 & & & & \\
\hline $25-130$ & 127.5 & & & & & $25-26$ & 25.5 & & & & & $25-26$ & 25.5 & & & & \\
\hline $120-126$ & 1225 & & & & & $24-25$ & 24.5 & & & & & $24-25$ & 24.5 & & & & \\
\hline $115-120$ & 117.5 & & & & & $23-24$ & 23.5 & & & & & $23-24$ & 23.5 & & & & \\
\hline $110-115$ & $112.5^{-1}$ & & & & & $22-23$ & 22.5 & & & & & $22-23$ & 22.5 & & & & \\
\hline $105-110$ & 107.5 & & & & & $21-22$ & 21.5 & & & & & $21-22$ & 21.5 & & & & \\
\hline $100-105$ & 102.5 & & & & & $20-21$ & 20.5 & 2 & 10 & 20 & 200 & $20-21$ & 20.5 & & & & \\
\hline $95 \div 100$ & 97.5 & & & & & $19-20$ & 195 & & 9 & & & $19-20$ & 19.5 & & & & \\
\hline $90-95$ & 92.5 & & & & & $18-14$ & 10.5 & 1 & 8 & 8 & 64 & $18-19$ & 18.5 & & & & \\
\hline $85-90$ & 87.5 & & & & & $17-18$ & 17.5 & & 7 & & & $17-18$ & 17.5 & & & & \\
\hline $80-65$ & 82.5 & & & & & $16-17$ & 16.5 & & 6 & & & $16-17$ & 16.5 & & & & \\
\hline $75-80$ & 77.5 & & & & & $15-16$ & 15.5 & 1 & 5 & 5 & 25 & $15-16$ & 15.5 & 1 & II & II & 121 \\
\hline $70-75$ & 72.5 & & & & & $14-15$ & 14.5 & 2 & 4 & 8 & 32 & $140 / 5$ & 14.5 & & 10 & & \\
\hline $65-70$ & 67.5 & 1 & 7 & 7 & 49 & $13-14$ & 13.5 & 2 & 3 & 6 & 18 & $13-14$ & 13.5 & & 9 & & \\
\hline $60-65$ & 62.5 & 1 & 6 & 6 & 36 & $12-13$ & 12.5 & 1 & 2 & 2 & 4 & $12-13$ & 12.5 & & 8 & & \\
\hline $55-60$ & 57.5 & & 5 & & & $11-12$ & 11.5 & 4 & 1 & $4+53$ & 4 & $11-12$ & 11.5 & & 7 & & \\
\hline $50-50$ & 52.5 & & 4 & & & $10-11$ & 10.5 & 5 & 0 & 0 & 0 & $10-11$ & 10.5 & & 6 & & \\
\hline $15-50$ & 47.5 & 2 & 3 & 6 & 18 & $4-10$ & 9.5 & 2 & -1 & -2 & 2 & $9-10$ & 9.5 & 1 & 5 & 5 & 25 \\
\hline 50.45 & 42.5 & 4 & 2 & 8 & 16 & $8-9$ & 8.5 & 4 & -2 & -8 & 16 & $8-9$ & 8.5 & 2 & 4 & 8 & 32 \\
\hline 3540 & 375 & 8 & 1 & $8+35$ & 8 & $7-8$ & 2.5 & 4 & -3 & -12 & 36 & $7-8$ & 7.5 & 4 & 3 & 12 & 36 \\
\hline $30-35$ & 32.5 & 7 & 0 & 0 & 0 & $6-7$ & 6.5 & $z$ & -4 & -8 & 32 & $6-7$ & 6.5 & 2 & 2 & 4 & 8 \\
\hline $25=30$ & 27.5 & 5 & -1 & -5 & 5 & $5-6$ & 5.5 & 2 & -5 & -10 & 50 & $5-6$ & 5.5 & 4 & 1 & $4+44$ & 4 \\
\hline $20-25$ & 22.5 & 3 & -2 & -6 & 12 & $4-5$ & 4.5 & 2 & -6 & -12 & 72 & $4-5$ & 4.5 & 12 & 0 & 0 & 0 \\
\hline $15-20$ & 17.5 & 2 & -3 & -6 & 18 & $3-4$ & 3.5 & 1 & -7 & -7 & 49 & $3-4$ & 3.5 & 4 & -1 & -4 & 4 \\
\hline $10-15$ & 12.5 & 3 & -4 & -12 & 48 & $2-3$ & 2.5 & 1 & -8 & $-8-67$ & 64 & $2-3$ & 2.5 & 2 & -2 & -4 & 8 \\
\hline $5-10$ & 7.5 & 1 & -5 & $-5-34$ & 25 & $1-2$ & 1.5 & & & & & $1-2$ & 1.5 & 2 & -3 & $-6-14$ & 18 \\
\hline $0-5$ & 2.5 & & & & & $0-1$ & 0.5 & & & & & $0-1$ & 0.5 & & & & \\
\hline$c=$ & $=.027$ & 37 & & +1 & 235 & c & $=-388$ & 36 & & -14 & 668 & \multirow{2}{*}{\multicolumn{2}{|c|}{$\begin{array}{l}c=.882 \\
c^{2}=.778\end{array}$}} & 34 & & +30 & 256 \\
\hline \multirow{2}{*}{\multicolumn{2}{|c|}{$\begin{aligned} C^{2} & =.00079 \\
C & =.135\end{aligned}$}} & \multicolumn{2}{|c|}{ Av. dist $=32.64$} & \multicolumn{2}{|c|}{$\sigma_{\text {dist }}=12.60$} & $c^{2}$ & $=.151$ & $A r_{\text {dist }}$ & $=10.11$ & $\sigma_{\text {dist. }}$ & $=4.29$ & & & \multicolumn{2}{|c|}{ Av. dist $=5.38$} & \multicolumn{2}{|c|}{$\sigma_{\text {dist }}=2.60$} \\
\hline & & \multicolumn{4}{|c|}{$P F_{a r}=1.397$} & & & \multicolumn{4}{|c|}{ PEar $=.4822$} & & & \multicolumn{4}{|c|}{$P F_{a r}=.3005$} \\
\hline
\end{tabular}

TABULATION OF ILL UMINATION

Fore

OULL DAYS IN ROOM "5, LNGRAMVILLE SCHOOK 


\section{DECREASE IN ILLUMTNATION BY DEST ROIS ACROSS ROON \#6, TAYLOR SGHOOL}

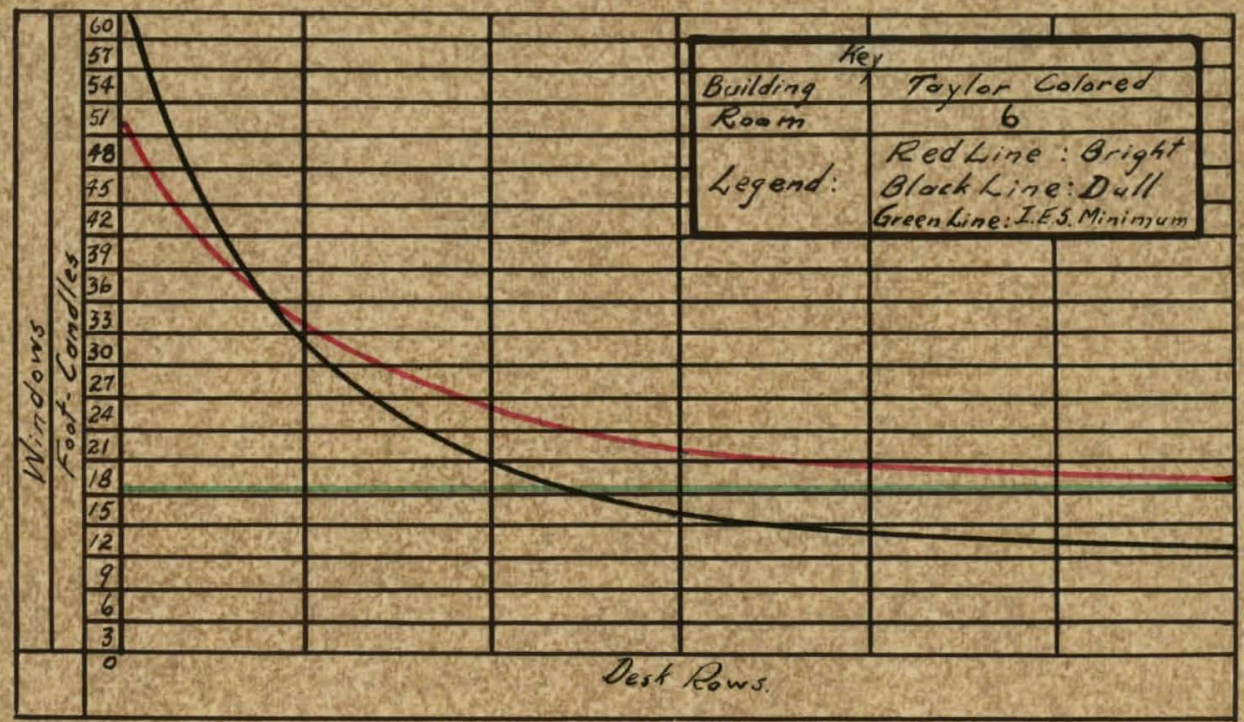

RIGURE 28

Illumination Level Distribution Cunves

T TABLE IIL

Statisticel Dorta for Lurves Above

\begin{tabular}{|c|c|c|c|}
\hline & $\begin{array}{l}\text { Mean Illumination } \\
\text { Foot Gondles } \\
\text { Dest-Toe. }\end{array}$ & $\frac{\text { Voriabilit/ }}{\left.\sigma_{d i s t}=\left(\frac{\sum F D^{2}}{N}\right)^{2}\right)^{1 / 2}}$ & 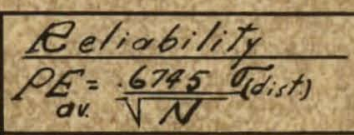 \\
\hline & 49.50 & 21.78 & 2.68 \\
\hline aे & 18.65 & 5.56 & 72 \\
\hline 0 & 16.32 & 5,55 & 71 \\
\hline & 62.15 & 13.69 & 1.43 \\
\hline 8 & 12.62 & 6.18 & .71 \\
\hline 8 & 9.47 & 5.44 & 68 \\
\hline
\end{tabular}


THBLE XX

\begin{tabular}{|c|c|c|c|c|c|c|c|c|c|c|c|c|c|c|c|c|c|}
\hline \multicolumn{6}{|c|}{ Seats Adjacent to Windows } & \multicolumn{6}{|c|}{ Seats of Conter } & \multicolumn{6}{|c|}{ Seat's Aljocent to Opposite Woll } \\
\hline Step & mid.pt & $F$ & 0 & $F D$ & $F D^{2}$ & stope & MideAt & $F$ & 0 & Fo & $F D^{2}$ & Step & Mif-Ax & $F$ & $D$ & FD & $F D^{2}$ \\
\hline $145-150$ & 147.5 & & & & & $29-30$ & 29.5 & 2 & 14 & 28 & 392 & $29-30$ & 29.5 & 2 & 12 & 24 & 288 \\
\hline $140-145$ & 142.5 & & & & & $28-29$ & 28.6 & & 13 & & & $28-24$ & 28.5 & & 11 & & \\
\hline $135-1 / 40$ & 137.5 & & & & & $27-28$ & 27.5 & & 12 & & & $27-28$ & 27.5 & & 10 & & \\
\hline (30-135 & 132.5 & & & & & $26-27$ & 26.5 & & II & & & $26-27$ & 26.5 & & 9 & & \\
\hline $25-130$ & 122.5 & & & & & $25-26$ & $25.5^{-}$ & 1 & 10 & 10 & 100 & $25-26$ & 25.5 & 1 & 8 & 8 & 64 \\
\hline (20\%/25 & 122.5 & 1 & 15 & 15 & 225 & $24-25$ & 24.5 & & 9 & & & 24.25 & 24.5 & & 7 & & \\
\hline $115-120$ & 117.5 & & 14 & & & $23-24$ & 23.5 & & 8 & & & $23-24$ & 23.5 & & 6 & & \\
\hline $110-115$ & 112.5 & & 13 & & & $22-23$ & 22.5 & 5 & 7 & 35 & 245 & $22-23$ & 22.5 & & 5 & & \\
\hline $05-110$ & 107.5 & & 12 & & & $21-22$ & 21.5 & 3 & 6 & 18 & 108 & $21-22$ & 21.5 & 2 & 4 & 8 & 32 \\
\hline $100-105$ & 102.5 & & II & & & $20-21$ & 20.5 & 2 & 5 & 10 & 50 & $20-21$ & 20.5 & 3 & 3 & $9+49$ & 27 \\
\hline $95 \% 100$ & 97.6 & & 10 & & & $19-20$ & 19.5 & 2 & 4 & 8 & 32 & $19-20$ & 19.5 & & $z$ & & \\
\hline $90-95$ & 92.5 & & 9 & & & $18-19$ & 10.5 & & 3 & & & $18-19$ & 18.5 & & 1 & & \\
\hline $85-90$ & 87.5 & 1 & 8 & 8 & 64 & $17-18$ & 17.5 & 1 & 2 & 2 & 4 & $17-18$ & 17.5 & 4 & 0 & 0 & 0 \\
\hline $80-85$ & 82.5 & 1 & 7 & 7 & 49 & $16-17$ & 16.5 & 2 & 1 & $2+113$ & 2 & $16-17$ & 16.5 & 1 & -1 & -1 & 1 \\
\hline $75-80$ & 72.5 & & 6 & & & $15-16$ & 15.5 & 3 & 0 & 0 & 0 & $15-16$ & 15.5 & 2 & -2 & -4 & 8 \\
\hline $70-75$ & 72.5 & 2 & 5 & 10 & 50 & $14-15$ & 14.5 & 1 & -1 & -1 & 1 & $18-15$ & 14.5 & 1 & -3 & -3 & 9 \\
\hline $65-70$ & 67.5 & & 4 & & & $13-14$ & 13.5 & 1 & -2 & -2 & 4 & $13-14$ & 13.5 & 1 & -4 & -4 & 16 \\
\hline $60-65$ & 62.5 & 1 & 3 & 3 & 9 & $12-13$ & 12.5 & & -3 & & & $12-13$ & 12.5 & 3 & -5 & -15 & 75 \\
\hline $55-60$ & 57.5 & 2 & 2 & 4 & 8 & $11-12$ & 11.5 & & -4 & & & $11-12$ & 11.5 & 2 & -6 & -12 & 72 \\
\hline $50-55$ & 52.5 & 6 & 1 & $6+53$ & 6 & $10-11$ & 10.5 & 2 & -5 & -10 & 50 & $10-11$ & 10.5 & 5 & -7 & -35 & 245 \\
\hline 15-50 & 47.5 & 4 & 6 & 0 & 0 & $9-10$ & 9.5 & & -6 & & & $9-10$ & 9.5 & 1 & -8 & $-8-82$ & 64 \\
\hline$\$ 0.45$ & 42.5 & 1 & -1 & -1 & 1 & $8-9$ & 8.5 & 1 & -7 & -7 & 49 & $8-9$ & 8.5 & & & & \\
\hline 3540 & 37.5 & 2 & -2 & -4 & 8 & $7-8$ & 7.5 & 1 & -8 & $-8-28$ & 64 & $7-8$ & 7.5 & & & & \\
\hline $30 \cdot 35$ & 32.5 & 4 & -3 & -12 & 36 & $6-7$ & 6.5 & & & & & $6-7$ & 6.5 & & & & \\
\hline $25 ; 30$ & 27,5 & 2 & -4 & -8 & 32 & $5-6$ & 5.5 & & & & & $5-6$ & 5.5 & & & & \\
\hline $20-25$ & 22.5 & 2 & -5 & -10 & 50 & $4-5$ & 4.5 & & & & & $4-5$ & 4.5 & & & & \\
\hline $15-20$ & 17.5 & 1 & -6 & $-6-41$ & 36 & $3-4$ & 3.5 & & & & & $3-4$ & 3.5 & & & & \\
\hline $10-15$ & 12.5 & & & & & $2-3$ & 2.5 & & & & & $2-3$ & 2.5 & & & & \\
\hline $5-10$ & 7.5 & & & & & $1-2$ & 1.5 & & & & & $1-2$ & 1.5 & & & & \\
\hline $0-5$ & 2.5 & & & & & $0-1$ & 0.5 & & & & & $0-1$ & 0.5 & & & & \\
\hline & & 30 & & +12 & 574 & \multirow{2}{*}{\multicolumn{2}{|c|}{$\begin{array}{l}c=3.148 \\
c^{2}=9.91\end{array}$}} & 27 & & +85 & 1101 & \multirow{2}{*}{\multicolumn{2}{|c|}{$\begin{array}{l}c=-1.178 \\
c^{2}=1.388\end{array}$}} & 28 & & -33 & 1901 \\
\hline \multicolumn{2}{|c|}{$\begin{array}{l}c^{2}=16 \\
c=2.0\end{array}$} & \multicolumn{4}{|c|}{$A r_{\text {dist }}=49.50 \quad \sigma_{\text {dist. }}=21.78$} & & & \multicolumn{4}{|c|}{$A r_{\text {dist. }}=18.65 \sigma_{\text {dist. }}=5.56$} & & & \multicolumn{4}{|c|}{ Arrdist: $=16.32 \sigma_{\text {dist. }}=5.55$} \\
\hline & & \multicolumn{4}{|c|}{$P E_{a r}=2.682$} & & & \multicolumn{4}{|c|}{$P_{a r}=.7211$} & & & \multicolumn{4}{|c|}{$P E_{\text {or }}=.7073$} \\
\hline \multicolumn{6}{|c|}{ Statistical } & \multicolumn{6}{|c|}{ Building: Toylor } & \multicolumn{6}{|c|}{ Room: 6 ||Conditions: Bright. } \\
\hline
\end{tabular}


THBLE XX

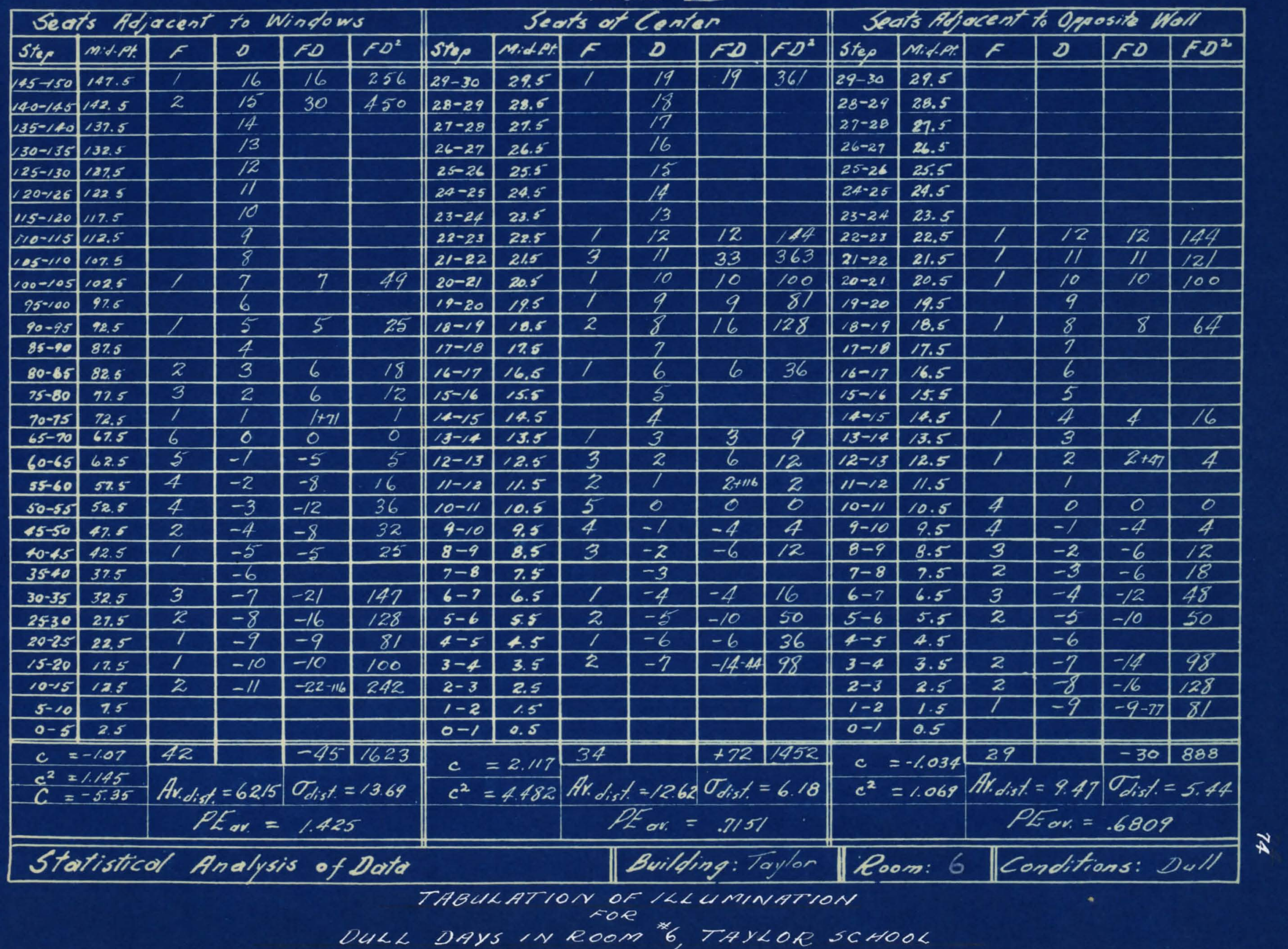


DECREASE IN IILUMTNATION BY DESK RONS ACROSS ROON \#Y, JUNIOR HIGH SCHOOL

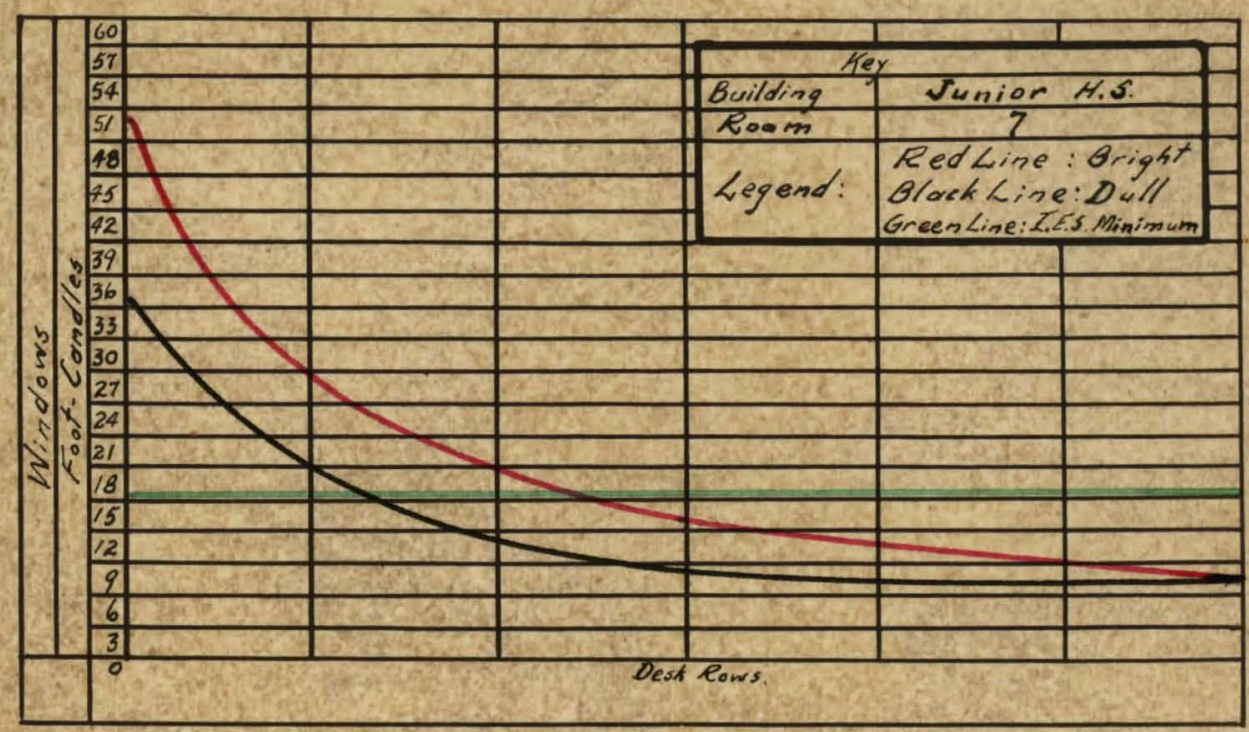

FIGURE
Illumination Level Distribution Curves

STAtistical Data for Curves Above

\begin{tabular}{|c|c|c|c|}
\hline & $\begin{array}{c}\text { Mean Illumination } \\
\text { Foot Condles } \\
\text { Dosk-Toe. }\end{array}$ & $\frac{\text { Variability }}{\sigma_{\text {dist }}=\left(\frac{\sum F D^{2}{ }^{2}}{N / / 2}\right.}$ & $\frac{\text { Eeliability }}{\rho E_{a v}=\frac{6745}{\sqrt{N}}(\text { dist }}$ \\
\hline \multirow{3}{*}{$\begin{array}{l}0^{0} \\
\frac{1}{2} \\
a^{2} \\
0^{2}\end{array}$} & 49.69 & 19.08 & 27 \\
\hline & 13.03 & 3.13 & 36 \\
\hline & 7.41 & 3.21 & 37 \\
\hline \multirow{3}{*}{$\begin{array}{l}0 \\
0\end{array}$} & 33.15 & 12.75 & 1.54 \\
\hline & 8.47 & 2.97 & .37 \\
\hline & 7. 24 & 3.02 & .36 \\
\hline
\end{tabular}


TABLE XX.

\begin{tabular}{|c|c|c|c|c|c|c|c|c|c|c|c|c|c|c|c|c|c|}
\hline \multicolumn{6}{|c|}{ Seats Adjacent to Windows } & \multicolumn{6}{|c|}{ Seats of Center } & \multicolumn{6}{|c|}{ Seats Aljocent to Opposite Woll } \\
\hline Step & mid.p. & $F$ & 0 & Fo & $F D^{2}$ & stop & Midest & $F$ & 0 & $F D$ & $F D^{2}$ & Step & Mi:At: & $F$ & 0 & Fo & $F D^{2}$ \\
\hline $45-150$ & 147.5 & & & & & $29-30$ & 29.5 & & & & & $29-30$ & 29.5 & & & & \\
\hline (40-1455- & 142.5 & & & & & $28-29$ & 28.6 & & & & & $28-29$ & 28.5 & & & & \\
\hline 135-1/40 & 137.5 & & & & & $27-28$ & 27.5 & & & & & $27-28$ & 27.5 & & & & \\
\hline $130-135$ & 132.5 & & & & & $26-27$ & 26.5 & & & & & $26-27$ & 26.5 & & & & \\
\hline $25-130$ & 127.5 & & & & & $25-26$ & $25.5^{-}$ & & & & & $25-26$ & 25.5 & & & & \\
\hline $20-126$ & 122.5 & & & & & $24-25$ & 24.5 & & & & & $24-25$ & 24.5 & & & & \\
\hline $115-120$ & 117.5 & 1 & 14 & 14 & 196 & $23-24$ & 23.5 & & & & & $23-24$ & 23.5 & & & & \\
\hline$\frac{110-1 / 5}{115}$ & $112.5^{\circ}$ & & 13 & & & $22-23$ & 22.5 & 1 & 10 & 10 & 100 & $22-23$ & 22.5 & & & & \\
\hline $105=110$ & 107.5 & & 12 & & & $21-22$ & 21.5 & & 9 & & & $2 /-22$ & 21.5 & & & & \\
\hline $100-105$ & 102.5 & & II & & & $20-21$ & $20.5^{\prime}$ & & 8 & & & $20-21$ & 20.5 & & & & \\
\hline $95 \div 00$ & 97.5 & & 10 & & & $19-20$ & 19.5 & & 7 & & & $19-20$ & 19.5 & & & & \\
\hline $90-95$ & 92.5 & & 9 & & & $18-19$ & 10.5 & 1 & 6 & 6 & 36 & $18-19$ & 18.5 & & & & - \\
\hline $85-90$ & 87.5 & & 8 & & & $17-18$ & 12.5 & & 5 & & & $17-18$ & 17.5 & & & & \\
\hline $80-85$ & 82.5 & & 7 & & & $16-17$ & 16.5 & 3 & 4 & 12 & 48 & $16-17$ & 16.5 & 1 & 10 & 10 & 100 \\
\hline $75-80$ & 77.5 & & 6 & & & $15-16$ & 15.5 & 1 & 3 & 3 & 9 & $15-16$ & 15.5 & 1 & 9 & 9 & 81 \\
\hline $70-75$ & 72.5 & 2 & 5 & 10 & 50 & $14-15$ & 19.5 & 4 & 2 & 8 & 16 & $14=/ 5$ & 14.5 & & 8 & & \\
\hline $65-70$ & 67.5 & 2 & 4 & 8 & 32 & $13-14$ & 13.5 & 7 & 1 & $7+46$ & 7 & $13-14$ & 13.5 & & 7 & & \\
\hline $60-65$ & 62.5 & 2 & 3 & 6 & 18 & $12-13$ & 12.5 & 8 & 0 & 0 & 0 & $12-13$ & 12.5 & 1 & 6 & 6 & 36 \\
\hline $55-60$ & 57.5 & 4 & 2 & 8 & 16 & \begin{tabular}{|l}
$11-12$ \\
\end{tabular} & 11.5 & 4 & -1 & -4 & 4 & $11-12$ & 11.5 & I & 5 & 5 & 25 \\
\hline $50-55$ & 52.5 & 3 & 1 & $3+49$ & 3 & $10-11$ & 10.5 & & -2 & & & $10-11$ & 10.5 & 7 & 4 & 4 & 16 \\
\hline $45-50$ & 47.5 & 8 & 0 & 0 & 0 & $9-10$ & 9.5 & 1 & -3 & -3 & 9 & $9-10$ & 9.5 & 3 & 3 & 9 & 27 \\
\hline 40.45 & 42.5 & 2 & -1 & -2 & 2 & $8-9$ & 8.5 & 1 & -4 & -4 & 16 & $8-9$ & 8.5 & 3 & 2 & 6 & 12 \\
\hline 3540 & 375 & 2 & -2 & -4 & 8 & $7-8$ & 7.5 & 1 & -5 & -5 & 25 & $7-8$ & 7.5 & 6 & 7 & $6+55$ & 6 \\
\hline $30-35$ & 32.5 & 1 & -3 & -3 & 9 & $6-7$ & 6.5 & 2 & -6 & $-1 / 2-28$ & 12 & $6-7$ & 6.5 & 8. & 0 & 0 & 0 \\
\hline $25: 30$ & 27.5 & 1 & -4 & -4 & 16 & $5-6$ & 5.5 & & & & & $5-6$ & 5.5 & 2 & -1 & -2 & 2 \\
\hline $20-25$ & 22.5 & 2 & -5 & -10 & 50 & $4-5$ & 4.5 & & & & & $4-5$ & 4.5 & 2 & -2 & -4 & 8 \\
\hline $15-20$ & 17.5 & 2 & -6 & -12.35 & 72 & $3-4$ & 3.5 & & & & & $3-4$ & 3.5 & 2 & -3 & -6 & 18 \\
\hline $10-15$ & 12.5 & & & & & $2-3$ & 2.5 & & & & & $2-3$ & 2.5 & 3 & -4 & $-12-24$ & 48 \\
\hline $5=10$ & 7.5 & & & & & $1-2$ & 1.5 & & & & & $1-2$ & 1.5 & & & & \\
\hline $0-5$ & 2.5 & & & & & $0-1$ & 0.5 & & & & & $0-1$ & 0.5 & & & & \\
\hline & 437 & 32 & & $+1 A$ & 472 & \multirow{2}{*}{\multicolumn{2}{|c|}{$\begin{array}{l}c=.529 \\
c^{2}=.280\end{array}$}} & 34 & & +18 & 1342 & & $=.911$ & 34 & & +31 & 374 \\
\hline \multirow{2}{*}{\multicolumn{2}{|c|}{$\begin{array}{l}c^{2}=.191 \\
c=2.185\end{array}$}} & \multicolumn{2}{|c|}{ Av. dist $=49.69$} & \multicolumn{2}{|c|}{$\sigma_{d i s t}=19.08$} & & & \multicolumn{2}{|c|}{ Arrdist $=13.03$} & \multicolumn{2}{|c|}{$\sigma_{\text {dist }}=3.13$} & \multicolumn{2}{|c|}{$c^{2}=.830$} & \multicolumn{2}{|c|}{ Ar. dist $=7.41$} & \multicolumn{2}{|c|}{$\sigma_{d i s t}=3.21$} \\
\hline & & \multicolumn{4}{|c|}{$P E_{a v}=2.27$} & & & \multicolumn{4}{|c|}{$P_{\text {ax }}=.3617$} & & & \multicolumn{4}{|c|}{$P E_{\alpha r}=.3715$} \\
\hline \multicolumn{6}{|c|}{ Statistical Analysis of Data } & \multicolumn{6}{|c|}{ Building: Nunion } & \multicolumn{2}{|c|}{ Poom: 7} & & ndits & ans: $b$ & Bright. \\
\hline
\end{tabular}


TABLE XXII

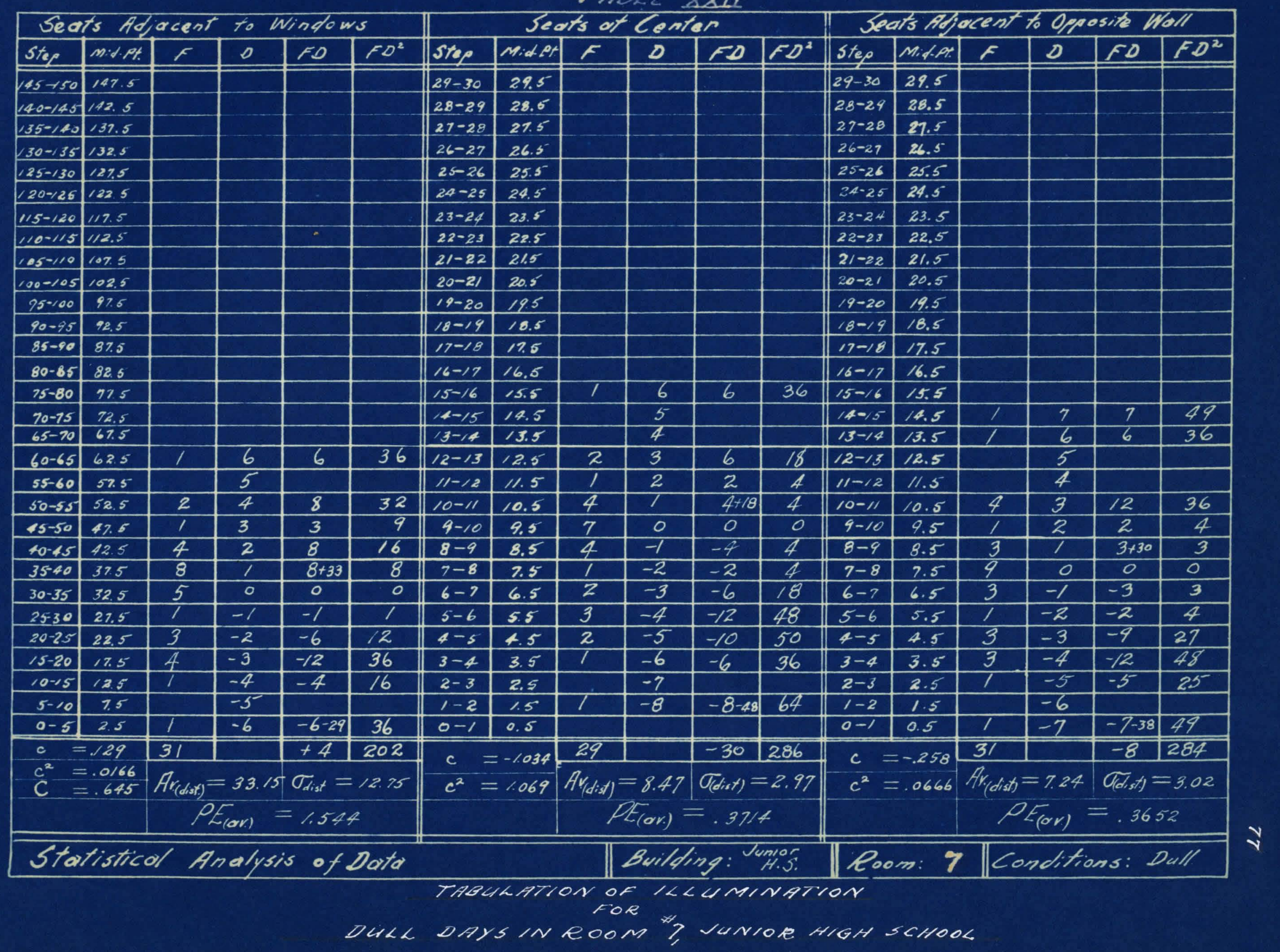


DEGREASE IN ILIUNINATION BY DESK ROWS ACROSS ROOM \#8, SENIOR HIGH SCHOOL

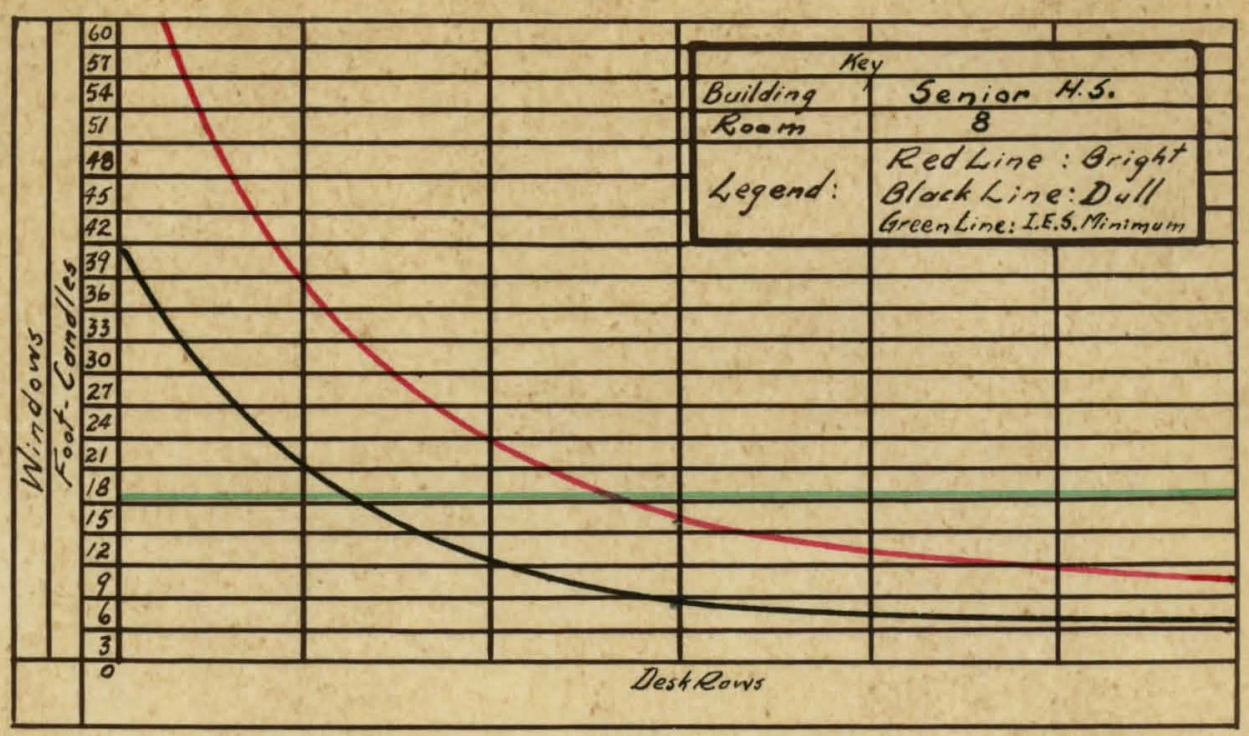

FIGURE 30

Illumination Level Distribution Cunves

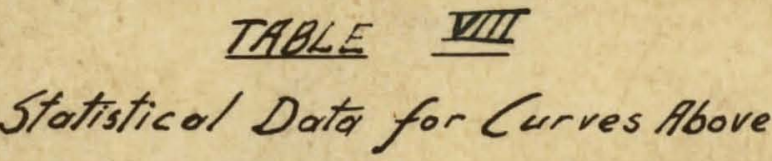

\begin{tabular}{|c|c|c|c|}
\hline & $\begin{array}{l}\text { Mean Illumination } \\
\text { Foot Condled } \\
\text { Desk- Top. }\end{array}$ & $\frac{\text { Variability }}{\sigma_{\text {dist }}=\left(\frac{\sum F D^{2}}{N}-c^{2}\right)^{1 / 2}}$ & $\frac{E_{e} \text { liability }}{\rho E_{\text {av }}=\frac{.6745 \text { (tist) }}{\sqrt{N}}}$ \\
\hline \multirow{3}{*}{ 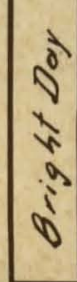 } & 81.09 & 35.91 & 4.28 \\
\hline & 12.73 & 6.23 & 77 \\
\hline & 7.74 & 2.93 & 34 \\
\hline \multirow{3}{*}{$\begin{array}{l}0 \\
0 \\
5 \\
0\end{array}$} & 38.54 & 20.06 & 2.51 \\
\hline & 5.64 & 2.60 & 33 \\
\hline & 3.63 & 2.53 & .32 \\
\hline
\end{tabular}


THBLE XXII

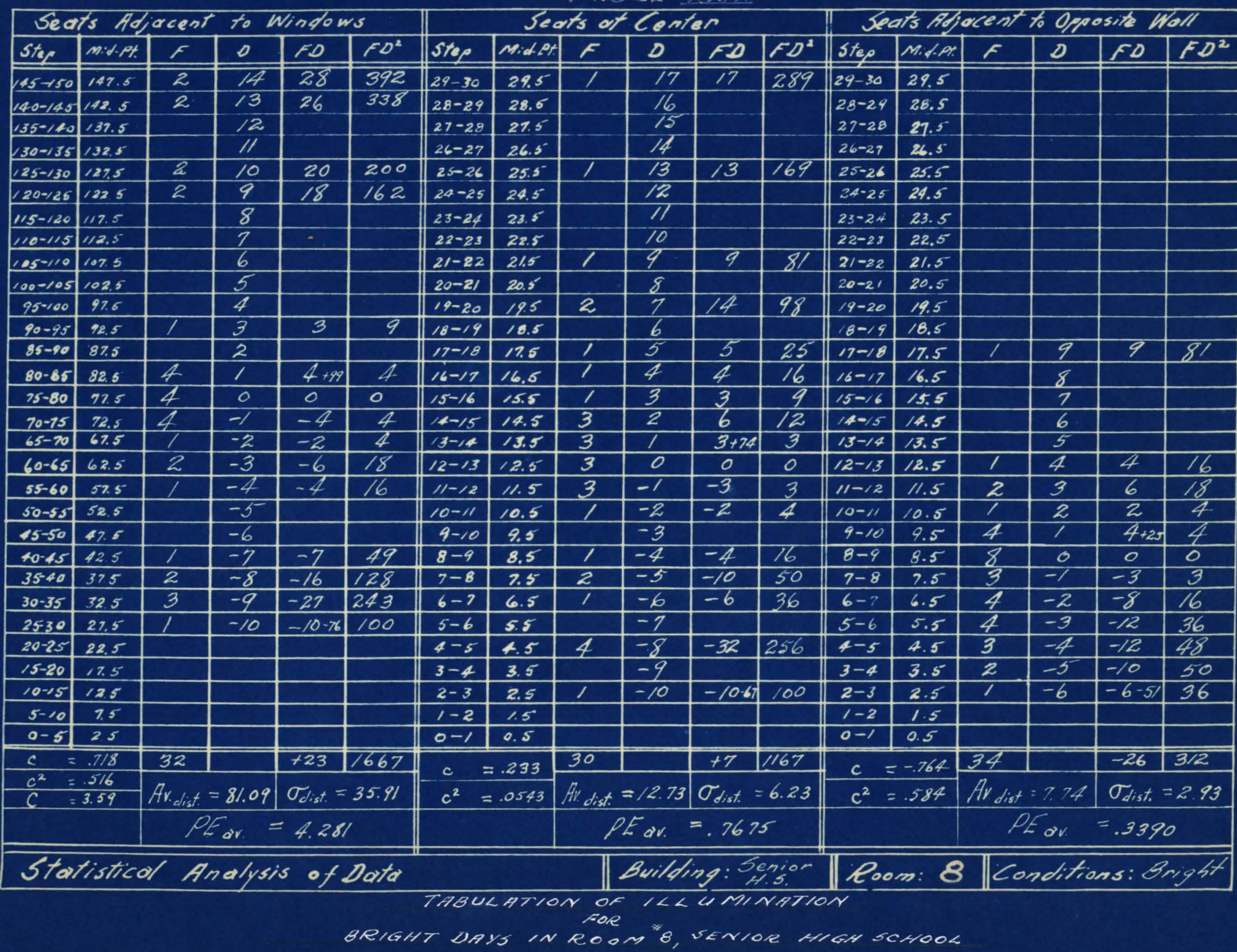


THBLE XXIV

\begin{tabular}{|c|c|c|c|c|c|c|c|c|c|c|c|c|c|c|c|c|c|}
\hline \multicolumn{6}{|c|}{ Adjacent } & \multicolumn{6}{|c|}{ Seats of Center } & \multicolumn{6}{|c|}{ Seats Algocent to Opposite Woll } \\
\hline Steg & m:d.pt. & $F$ & 0 & $F D$ & $F D^{2}$ & Stop & MidPe. & $F$ & 0 & $F 0$ & $F D^{2}$ & Step & Mid.PT. & $F$ & 0 & FD & $F D^{2}$ \\
\hline $45-150$ & 147.5 & & & & & $29-30$ & 29.5 & & & & & $29-30$ & 29.5 & & & & \\
\hline $40-145$ & 142.5 & & & & & $28-29$ & 28.6 & & & & & $28-29$ & 28.5 & & & & \\
\hline $355-140$ & 137.5 & & & & & $27-28$ & 27.5 & & & & & $27-28$ & 27.5 & & & & \\
\hline$(30-135$ & 132.5 & & & & & $26-27$ & 26.5 & & & & & $26-27$ & $26.5^{\circ}$ & & & $\cdot$ & \\
\hline $25-130$ & 127.5 & & & & & $25-26$ & $25.5^{-}$ & & & & & $25-26$ & 25.5 & & & & \\
\hline$(20-126)$ & 1225 & & & & & $24-25$ & 24.5 & & & & & $24-25$ & 24.5 & & & & \\
\hline $115-120$ & 117.5 & & & & & $23-24$ & 23.5 & & & & & $23-24$ & 23.5 & & & & \\
\hline $110-115$ & $112.5^{\circ}$ & & & 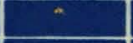 & & $22-23$ & 22.5 & & & & & $22-23$ & 22.5 & & & & \\
\hline $105-110$ & 107.5 & & & & & $21-22$ & 21.5 & & & & & $21-22$ & 21.5 & & & & \\
\hline $100-105$ & 102.5 & 1 & 12 & 12 & 144 & $20-21$ & $20.5^{\prime}$ & & & & & $20-21$ & 20.5 & & & & \\
\hline $95-100$ & 97.6 & & 11 & & & $19-20$ & 19.5 & & & & & $19-20$ & 19.5 & & & & \\
\hline $90-95$ & 92.5 & & 10 & & & $18-19$ & 10.5 & & & & & $18-19$ & 18.5 & & & & \\
\hline $85-90$ & 87.5 & & 9 & & & $17-18$ & 17.5 & & & & & $17-10$ & 17.5 & & & & \\
\hline $80-85$ & 82.5 & & 8 & & & $16-17$ & 16.5 & & & & & $16-17$ & 16.5 & & & & \\
\hline $75-80$ & 77.5 & & 7 & & & $15-16$ & 15.5 & & & & & $15-16$ & 15.5 & & & & \\
\hline $70-75$ & 72.5 & & 6 & & & $14-15$ & 19.5 & & & & & $14-15$ & 14.5 & & & & \\
\hline $65-70$ & 67.5 & & 5 & & & $13-14$ & 13.5 & & & & & $13-14$ & 13.5 & & & & \\
\hline $60-65$ & 62.5 & 2 & 4 & 8 & 32 & $12-13$ & 12.5 & 1 & 7 & 7 & 49 & $12-13$ & 12.5 & & & & \\
\hline $55-60$ & 52.5 & 1 & 3 & 3 & 9 & $11-12$ & 11.5 & & 6 & & & $11-12$ & 11.5 & & & & \\
\hline $50-55$ & 52.5 & 3 & 2 & 6 & 12 & $10-11$ & 10.5 & & 5 & & & $10-11$ & 10.5 & 2 & 8 & 16 & 128 \\
\hline $15-50$ & 47.5 & 4 & 1 & $4+33$ & 4 & $9-10$ & 9.5 & 7 & 4 & 4 & 16 & $9-10$ & 9.5 & & 7 & & \\
\hline $40-45$ & 42.5 & $A$ & 0 & 0 & 0 & $8-9$ & 8.5 & 4 & 3 & 12 & 36 & $8-9$ & 8.5 & & 6 & & \\
\hline $354 a$ & 375 & 1 & -1 & -1 & 1 & $7-8$ & 7.5 & 3 & 2 & 6 & 12 & $7-8$ & 7.5 & 1 & 5 & 5 & 25 \\
\hline $30-35$ & 32.5 & 4 & -2 & -8 & 16 & $6-7$ & 6.5 & 1 & 1 & $1+30$ & 1 & $6-7$ & 6.5 & 2 & 4 & 8 & 32 \\
\hline $25=30$ & 27.5 & 1 & -3 & -3 & 9 & $5-6$ & 5.5 & 7 & 0 & 0 & 0 & $5-6$ & 5.5 & & 3 & & \\
\hline $20-25$ & 22.5 & 3 & -4 & -12 & 48 & $4-5$ & 4.5 & 4 & -1 & -4 & 4 & $4-5$ & 4.5 & 5 & 2 & 10 & 20 \\
\hline $15-20$ & 17.5 & 1 & -5 & -5 & 25 & $3-4$ & 3.5 & 1 & -2 & -2 & 4 & $3-4$ & 3.5 & 4 & I & $4+43$ & 4 \\
\hline $10-15$ & 12.5 & 2 & -6 & -12 & 72 & $2-3$ & 2.5 & 4 & -3 & -12 & 36 & $2-3$ & 2.5 & 7 & 0 & 0 & 0 \\
\hline $5-10$ & 7.5 & 1 & -7 & -1 & 49 & $1-2$ & 1.5 & 2 & -4 & $-8-26$ & 32 & $1-2$ & 1.5 & 6 & -1 & -6 & 6 \\
\hline $0-5$ & 2.5 & 1 & -8 & $-8-56$ & 64 & $0-1$ & 0.5 & & & & & $0-1$ & 0.5 & 2 & -2 & $-4^{-10}$ & 8 \\
\hline$c=$ & -.793 & 29 & & -23 & 485 & $c$ & $=.142$ & 28 & & +4 & 190 & $c=$ & 1.13 & 29 & & +33 & 223 \\
\hline $\begin{array}{l}c^{2}= \\
c=-\end{array}$ & $\frac{.629}{-3.965}$ & $A v$ (dist) & $=38.54$ & $\sigma_{\text {dist }}=$ & 20.06 & $c^{2}=$ & .0202 & Arr. dist. & $=5.64$ & $\sigma_{\text {dist: }}=$ & 2.60 & $c^{2}=$ & 1.277 & $A_{x}$ dist & $=3.63$ & $\sigma_{\text {dist. }}=$ & 2.53 \\
\hline & & $P_{2}$ & $\sigma_{r r}=$ & 2. 512 & & & & & $E_{a x}=$ & .3315 & & & & & $f(o r)=$ & $3 / 71$ & \\
\hline
\end{tabular}


THELE XXY

\begin{tabular}{|c|c|c|c|c|c|c|c|c|c|c|c|c|c|c|c|c|c|}
\hline \multirow{2}{*}{ Building. } & & \multicolumn{6}{|c|}{ Seats hifacent to Windows } & \multicolumn{5}{|c|}{ Seats of Center } & \multicolumn{5}{|c|}{ Seats Near queosite Wall } \\
\hline & & c & $c^{2}$ & C & Avdist & $\sigma_{\text {dist }}$ & $P E_{\alpha r}$ & c & $c^{2}$ & Ardest & $\sigma_{\text {dist }}$ & Pt & c & $c^{2}$ & Ar.dist & $\sigma_{\text {dist }}$ & Ptor. \\
\hline \multirow{2}{*}{$\begin{array}{l}\text { Rose } \\
\text { Hill }\end{array}$} & B.t. & .828 & .686 & 4.140 & 56.64 & 23.585 & 2.689 & .114 & .013 & 11.614 & 4.327 & .4933 & .561 & .315 & 8.061 & $3.851:$ & 4057 \\
\hline & $D$ & 1.40 & 1.96 & 7.00. & 34.5 & 18.283 & 2.252 & .116 & .0276 & 8.666 & $4.265^{-}$ & 4795 & .52 & .270 & 5.98 & 4561. & .6153 \\
\hline \multirow{2}{*}{$\begin{array}{l}\text { Chestrut } \\
\text { Street }\end{array}$} & Brt & .077 & .0059 & .385 & 42.89 & 35,060 & 4.373 & .851 & .724 & 12.351 & 4.560 & .5919 & .148 & .0219 & 12.648 & 6.626 & .8601 \\
\hline & $D$ & 1.25 & 1.563 & 6.25 & $38.75^{-}$ & 27.43 & 2.6705 & 1.172 & 1.373 & 9.672 & 5.855 & .5186 & .627 & .393 & 10.127 & 7.628 & .7241 \\
\hline \multirow{2}{*}{$\begin{array}{l}5 \text { pring } \\
\text { Hill }\end{array}$} & Brt. & -1.307 & 1.708 & -6.54 & 85.97 & 39.985 & 4.319 & 2.276 & 5.180 & 19.776 & 6.266 & .6165 & .239 & .057 & 9.261 & 3.170 & .3153 \\
\hline & $D$ & 0 & 0 & 0 & 42.5 & 18.40 & 20077 & .319 & .102 & 9.819 & 4.019 & .3954 & 1.15 & 1.323 & 4.65 & 2.334 & .2162 \\
\hline \multirow{2}{*}{$\begin{array}{l}\text { Port } \\
\text { Fulton }\end{array}$} & Brt. & 2.36 & 5.570 & 118 & 44.3 & 17.54 & 2.366 & .303 & .092 & 14.803 & A648 & .5458 & .333 &.$I I I$ & $1 / .833$ & 3.762 & .4633 \\
\hline & & -.518 & .268 & -2.57 & 34.9 & $17.915^{3}$ & 2.326 & .4 & .16 & 12.90 & 6.159 & .7585 & .516 & .266 & 8.016 & 3.600 & .4361 \\
\hline \multirow{2}{*}{$\begin{array}{r}\text { union } \\
4.5\end{array}$} & Brt & .437 & .191 & 2.85 & 49.69 & 19.075 & 2.274 & .529 & .280 & 13.029 & 3.127 & 3617 & .911 & .830 & 7.411 & 3.212 & .3715 \\
\hline & $D$ & .129 & .0166 & .645 & 33.15 & 12.745 & -1.544 & -1.034 & 41069 & 8.466 & $2.965^{-}$ & .3714 & .258 & .0666 & 7.242 & 3.015 & .3652 \\
\hline \multirow{2}{*}{$\begin{array}{r}\text { Senior } \\
4.5\end{array}$} & Brt. & .716 & .516 & 3.59 & 81.09 & 35.905 & 4.281 & .233 & .0543 & 12.733 & 6.232 & .7675 & -.764 & .584 & 7.736 & 2931 & .3390 \\
\hline & $D$ & -.793 & .629 & -3.965 & 38.54 & 20.055 & 2.512 & .142 & .0202 & 5.642 & 2.601 & .3315 & 1.13 & 1.277 & 3.63 & 2.532 & $3 n 1$ \\
\hline \multirow{2}{*}{ Ingramville } & Brt. & -4.657 & 21.632 & -23.26 & 64.25 & 35.710 & 3.673 & $-4,5$ & 19803 & 19.05 & 7118 & $.75 \%$ & .575 & .331 & 11.075 & 6.711 & .7879 \\
\hline & $D$ & .027 & .00073 & 1.135 & 32.64 & 12.595 & 1.397 & -388 & .151 & 10.112 & 4.289 & A822 & .892 & .778 & 5.382 & 2.598 & .3005 \\
\hline \multirow{2}{*}{ Taylor } & Brt & .4 & .16 & 2.0 & 49.50 & 21.775 & 2.6815 & 3.148 & 9.910 & 18.648 & 5.555 & .7211 & -1.178 & 1.388 & 16.322 & 5.549 & .7073 \\
\hline & $D$ & -1.07 & 1.145 & -5.35 & 62.15 & 13.690 & 1.425 & 2117 & $4.482 \mid$ & 12.617 & 6.182 & .7151 & -1.034 & 1.069 & 9.466 & 65.436 & .6809 \\
\hline
\end{tabular}


CHAPTER VI

CONCLUSIONS AND RECOMMENDATIONS 


\section{CONCLUSIONS AND RECOMMENDATIONS}

Since two of the three initial purposes of analyzing and grapnically representing the illumination conditions nave been fulfilled, there jet remains the tnird original intention of comparing the findings with the accepted norms.

The green horizontal line on each of the illumination level distribution curves represents the IlJuminating Engineering Society's recommended minimurn for classroom lighting practice. Altnough tnis norm is set at fifteen foot-candles, it must be tnorougnly understood that higher values are not only unobjectionable, but highly desirable.

From a consideration of the curves, it is obvious that the light on dull days, in all instances, falls to or below the recommended minimum at a distance no more remotely removed than the row of desks whych is second from the windows. Even on bright days this minimum is reached at a point about midway between the windows and tre opposite wall. In rounded fractions, this means that the rooms, on dull days, are inadequately lighted for about two-thirds of tneir area. On brignt days, about one-half of the desks receive illumination tnat is below the recommended minimum standard.

An additional conclusion, evident from the calculations, relates to the statistical reliability of the data. In all cases, the least reliable measures were those obtained 
adjacent to the windows. The probable error of the average in these locations indicates that the chances are even that the true average may differ from the obtained average by an amount verying from slightly more than one foot-candle to an amount as large as four foot-candles. However, since tre light values near the windows are large, tnis probable error, ranging from one to four foot-candles, becomes insignificant when considered on a percentage basis. The probable error of all other measurements taken at points removed from tne windows indicates a considerably higher reliability. In each of these cases, it is possible to predict that tne chances are even that the true average differs from the obtained a verage by an amount considerably less than one foot-candle. This error is entirely within the limitations of the instruments used, especially since no attempt was made to read the meters in terms of fractions of a foot-candie. A few recommendations are indicated in connection with any furtier study in the field of illumination. After this study had been completed, the General Electric Company announced a new light meter, which, according to specifications, is superior in its versatility to those used in this survey. Since tnis new instrument has a maximum range of sevenbundred foot-candles, it could roplace both of the instruments used in this survey at approximately one-fourth of the cost. 
Precision tolerances to the nearest thousandth part of an inch would not have been necessary in making tne special masks used in this study, if a simpler perforated type had been calibrated by trial and error.

Recommendations for the improvement of the lighting conditions would entail, for the most part, structural alterations in the physical properties of the rooms. The most important of these would involve the repositioning of tne Incandescent I uminares, in order to increase the inadequate 1 llumination near the wall opposite the windows. The best practice in tnis respect seems to sanction the placing of two parallel rows of artificial lignts, energized by independently controlled circuits. Often the inner-most row contains lights of higher wattage than those rows nearer the windows. The lowering of the luminares to increase the Illumination is not to be recommended because of the high probability of attendant glare in the line of vision. AII artificial light sources should, for tne same reason, be enclosed in diffusing translucent globes.

Many improvements in the lighting conditions could be made without involving any additional expense, if attention were given to the details. Increased illumination efficiency can be effected by the maintenance of both window areas that are clean and lighting fixtures trat have not accumulated 
opaque dirt. When replacement is necessary, opaque window shades should be superseded by those that are translucent. Likewise, when the occasion demands, repainting should be done in the colors that are high in their reflection-factors. Specifically, if one were cnarged with improving tne general illumination of classrooms within a given system, a definite procedure would be expedient. A time scnedule for the collection of the raw data for all rooms concerned should be carefuliy planned. AII teacners in the system should be acquainted with the importance of adequate lighting in order that the observations would be taken under the optimum conditions. This step could be economically profitable in many situations by reducing the expense of unnecessary electrical installations.

Next, a comprenensive integration of the observed facts snould be synthesized by the use of some technique similar to that employed in this particular study. If the actual survey were made after proper attention was given to the previously mentioned recommendations concerning cleanliness and reflection-factors of wall surfaces, then a competent 1llumination engineer snould be asked for an estimate and specifications for the required corrections.

In consideration of the natural variations encountered in tnis particular inquiry, too much empnasis cannot be placed 
upon the necessity of avoiding fallacious results derived from a paucity of meter readings.

Perhaps much improvement could be made, in any school system, by the frequent use of a light meter. The psychological effect of the lignt meter upon tne teacher, who usually controls the adjustment of window snades and the use of the artificial lights, can cause this individual to become light conscious. Since the numan eye is a very poor light meter, the value of some device that is accurate cannot be overestimated.

Although, on the surface, it may seem apparent that this survey reveals deplorable inadequacy in classroom illumination, it should be borne in mind that the modern standards are exceptionally high. Our educational institutions have not always been primarily concerned with the high standards of illumination. However, a description by Williard Samuel of the provisions for light in the early schoolhouses is illustrative of the general practice until as late as 1835, and in some sections of the country until much later. He said that: "On at least one side of the schoolnouse, the space between two logs would be left open to admit lignt; and this window would be closed by greased paper 
to exclude rain and snow." 1

The progress mede in classroom illumination in the

past one hundred years has been remarkable, indeed.

I F. R. Noffsinger, "A Century of Progress in Schoolroom Iighting," American School Board Journal, 96:75 April, 1938. 
BIBLIOGRA PHY 


\section{A. BOOKS}

American Standards Association, American Recomended Practice of School Lighting. New York: IIluminating Society, 1938 .

Barrows, W. E., Light, Pnotometry and Illuminating Engineering. $\sqrt{e w}$ York: McGraw Hil Book Company, 1938.

Bragg, J., Universe of Light. New York: McMillan Comapny, 1938.

Brandt, K., Light Filters. Now York: American Photographic Publishers, 193\%.

Cady, F. E. and Henry B. Dates, Illuminating Engineering. New York: John Wiley and Sons, Inc., 1925.

Crew, Henry, The Wave Theory of Iight. New York: American Book Company, 1900 .

Croft, Terrell, Practical Electrical Illumination. New York: McGraw Hili Book Compañ, 191\%.

Fletcher, G. L., Mosbacher and Lehman, S., Unifled Physics. New York: McGraw Hill Book Company, 1936.

Fuller, R. W., Brownlee, R. B. and Baker, D. Le日, First Principles of Physics. Boston: Allyn and Bacon, 1936.

Handbook of Chomistry and Physics. 19th. edition. Cleveland, Ohio: Chemical Rubber Publishing Company, 1934.

Henderson, W. D., The Physics in Everyday Iife. Cnicago: Lyons and Carnahan, 1936.

Illuminating Engine Practice of School lighting. New York: American Standards Association, February, 1938.

Luckiesh, Matthew, Iight and Work. New York: D. Van Nostrand Company, 1924.

Luckiesh, Matthew, Artificial Sunlight. New York: D. Van Nostrand Company, 1930. - 
Lucklesh, liat tnew, Seeing. Beltimore: The Williams and Wilkins Company, 1931.

Lucklesh, Matthew, The Science of Seeing. New York: D. Van Nos trand Compan $\bar{y}, 1937$.

Millikan, R. A. and H. G. Gale, New Elementary Physics. Boston: Ginn and Company, $19 \overline{36}$.

Millikan, R. A, and Jonn Mills, Electricity, Sound and Iight. Boston: Ginn and Company, 1908 .

Monk, G. S., Light: Principles and Experiments. New York: McGraw Hill Book Company, 1937.

Noakes, G. R., Textbook of Light. New York: Necmillan Company, 1937.

Rosa, Ed. B., Lectures on Illuminating Engineering. Baltimore: The Johns Hopkins Press, 1911.

Stewart, 0. M., Physics: A Textbook f or Colleges. Boston: Ginn and Company, 1924. 


\section{B. PERIODICA IS}

Albert, E. C., "Scholarship Improved by Light," Transactions of the I. E. S., $28: 866,1933$.

Barker, J. W., "Some Aspects of Library Iighting from the Standpoint of an Illuminating Engineer," Iibrary Jr.,

Cornet, G. A., "Modern Views on Lignting," Netions School,
19:53-7, June,

Darley, W. G., "Ii ght For Easier Se日ing," Nations School, 20:62, September, 1937.

Digest, "Dirt Ad15:26, March 4, 1933.

Dresslar, F. B., and soutnerland, R. H., "Orientation of Classrooms of School Buildings," Peabody Jr. of Education, $7: 3-12$, Ju1J, 1929 .

Eaton, J., "Better Iight, Better Sight," Pictorial Review, $35: 25$, December, 1933 .

Flagler, L. D., "Experiment in Classroom Illumination," American School Board Jr., 96:80, January, 1938 .

Frostic, F. W., "Ancient and Dirty Light Fixtures vaste Power and Harm Eyes," Nations School, 12:61-3, December, 1933.

Frostic, F. W., "Automatic Iight Control is Needed in the Modern School," Nations School, 12:II-14, November, 1933.

; "Good Lignt for the Schoolroom," School Executives, $49: 81$, October, 1929 .

Gradle, H. S., "Ijgnting the Scnoolroom," Hygiea, 15:1097-9, December, 1937 .

Halsey, R. H. F., "How Much Light for Scnoolrooms?" American School Board Jr., 96:27-8, January, 1938 . 
Hamon, R. L. and Taylor, L. H., "What Effect has the Horizontal spacing of Classroom windows on the Distribution of Lignt?" American School Board Jr., 87:28-9, October, 1933 .

Hathaway, W., "Well Iighted Schoolhouse, a Cooperative Effort," Nations School, 6:55-8, July, 1930.

Henderson, O. G., and Rowell, H. G., "Light to save your Eyes," American Home, 10:280, November, 1933.

Hillyer, E., "Good Light Saves Wear and Tear on Eyes, Nerves, and Dispositions," Delineator, 130:4, February, 1937.

Holmes, W. J., "Good Lighting and Scholarship," School Executives, 57:72-3, October, 1937 .

Hopkinson, G. M., "Natural and Artificial Lighting of Schoolrooms," American School Board Jr., 8I:4I-2, October, 1930 .

Ives, J. E., "Review of Cur rent Practice in the Lighting of School Buildings in the United States," American School Board Jr., 78:140, May, 1929.

Jackson, E., "Doctor Looks on Iighting," Nations School, $20: 55$, August, 1937.

Jonnston, H. L., "Better Scnool Lighting Pays," Electrical Wor 1d, 104:1078, July, 1934. March, I938. ; "Light and Heat," Time, Vol. 31: No. 13,

Logan, H. L., "Lighting the Classroom More Effectively With Less Illumination," Architect Record, 75:533, June, 1934.

Luckiesh, M., "Research in Vision Will Revolutionize Lighting," American City, 50:109, June, 1935.

Luckiesh, M., "Eyes Should Have It," Good Housekeeping, $99: 88-9$, November, 1934 .

Luckiesh, M., "Iight for Children's Sight," Parents, 12:28, October, 1937 . 
Martin, A. J., "Schoolroom Day-Lighting," American School Board Jr., $82: 65$, May, 1931 .

McKinlay, H. G., "Good Lighting Helps Children Study." Pictorial Review, 35:38, October, 1933.

; "New Light for Young Eyes," Parents, 10:32-3, November, 1935 .

Noffsinger, F. R., "A Century of Progress in Schoolroom Lighting," American School Board Jr., 96:75, April, 1938.

Phelan, A. M., "Day-Lighting the Schoolroom," Childhood Education, 14:17-21, September, 1937.

Rigast, A. K.,"Hygiene of Vision in School Drafting Room," Ind. Arts and Voc. Ed., $21: 213-215$ and 239-41, JulyAugust, 1932

Rodgers, A., "Control of Light and Better Light for the Classroom," Architect Record, 79:504-9, June, 1936.

Rowell, H. G., "Turning the Iight on School Lignting," National Parent Teacher, 30:12-13, December, 1935. ; "Scholarship Improved by Adequate Light," Electrical World, 102:347, September 9, 1933. Ju1g, 1934 . ; "Too Much Illumination," Sci. Am. 151:8, 


\section{PAMPHLETS}

Allphin, Williard, Does School Lighting Influence Scholarship? Buffalo: Transactions IIluminating Engineering Soclety, September, 1936.

; "Care of the Eyes," Nelfare Bulletin, No. 500 L. N. TNow York: Metropolitan Life Insurance Co.T.

Caverly, Donald P., Classroom Li ghting wi th Automatic Control. (Lynn, Massachusetts: Lynn Gas and Electric Co., 1937).

Clark, Talaferro, Studies in Natural Illumination. (Washington: Government Document, T27. 12, No. 159).

; "Classroom Iignting and its Influences," Reprinted from Magazine of Light. Cleveland, Ohio: Nela Park Research Division of General Electric, 1936.

Cobb, Percy W., "Lighting f or the Conservation of Vision," New York: National Society for Prevention of Blindness. Publication No. 123, 1933.

; "Code of Lighting Factories, Mills and Other Work Places," Bulletins $329-323$ of U. S. Bureau of Labor Statistics, (Wasnington: Government Document, 1923).

; "Code of Lighting," Bulletin L. D.-6. (Cleveland, Ohi o: Nela Park Division, General Elēctric).

Harrison, Ward, and Staley, K. A., Fundamentals of

Illumination, Bulletin L. D.-iA. Cleveland, Onio:

Nela Park Engineering Dept., General Electric Research, 1931 .

Hathaway, Ninifred, "Lighting the Rural School." New York: National Society $f$ or Prevention of Blindness, Reprinted from Public Heal th Num sing, September, 1935.

Hathaway, Winifred, "Lighting the Home for Health and Happiness." New York: National Society for Prevention of Blindness, Publication №. 53, 1936 . Document, "Home and Scnool Lighting," New York State
Ag, 2-3, No. 374. 
; Illuminating Engineering Nomenclature and Photometric Standards, New York: Trans. Illuminating Engineering Society, No. 25, 1930.

Kraehenbuenl, J. 0., "Investigation of Student Study Lignting," Research Bulletin. Urbana, Illinols: University of IIlinois Press, 1937.

Krenenbuenl, J. 0., "Problems in Building Illumination," Research Bulletin. Urbana, Illinois: University of IIlinois Press, I937.

; "Lighting," Bulletin E-108, Pittsburgn: Westinghouse Lamp Corp.

; "Lighting at School and at Home," Health

Bulletin for Teachers, Vol. VIII, (New York: Netropolitan Iife Insurance Co., June, 1937).

; "Mortality of the Blind," Statistical

Bulletin, 16: No. 9, Metropolitan Life Insurance Co., September, I935.

Rosa, E. B., Lectures on Illuminating Engineering. (Baltimore: The Jonn Hopkins Press, 1911).

; Rules and Regulations of the Division of Public Health, State Of Indiana - Indianapolis: Indiana state Dept. of Public Health.

; "Studies in Illumination," Government

Document, T27:12, No. 140 .

; "Studies in IIlumination," Washington: U. S. Public Fealth Bulletin, No. 181.

Tang, K. Y., Effect of Quality and Intensity of Light on Visual Performance, TColumbus, Ohio: Ohio State University Press, 1934). 
A PPENDIX 


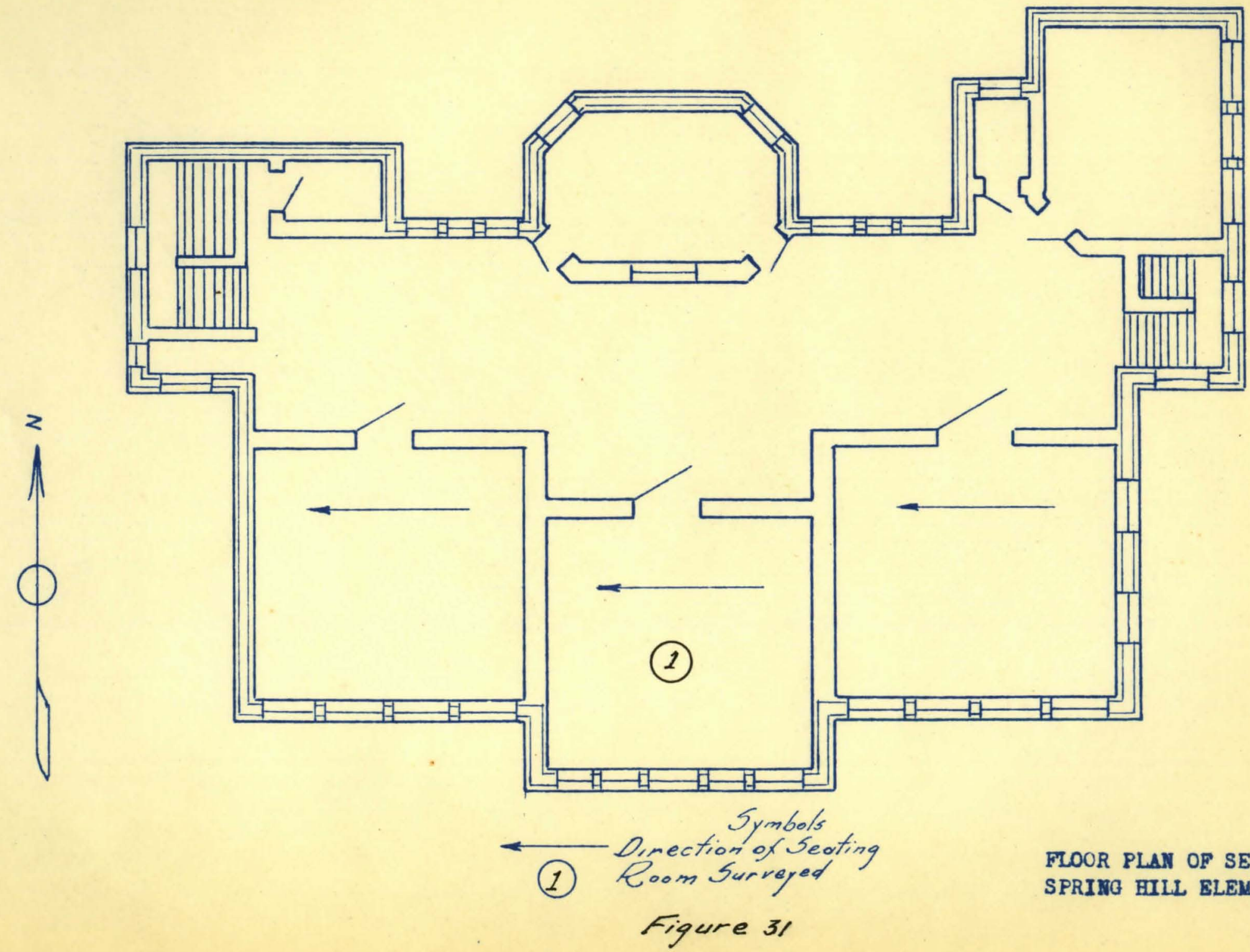



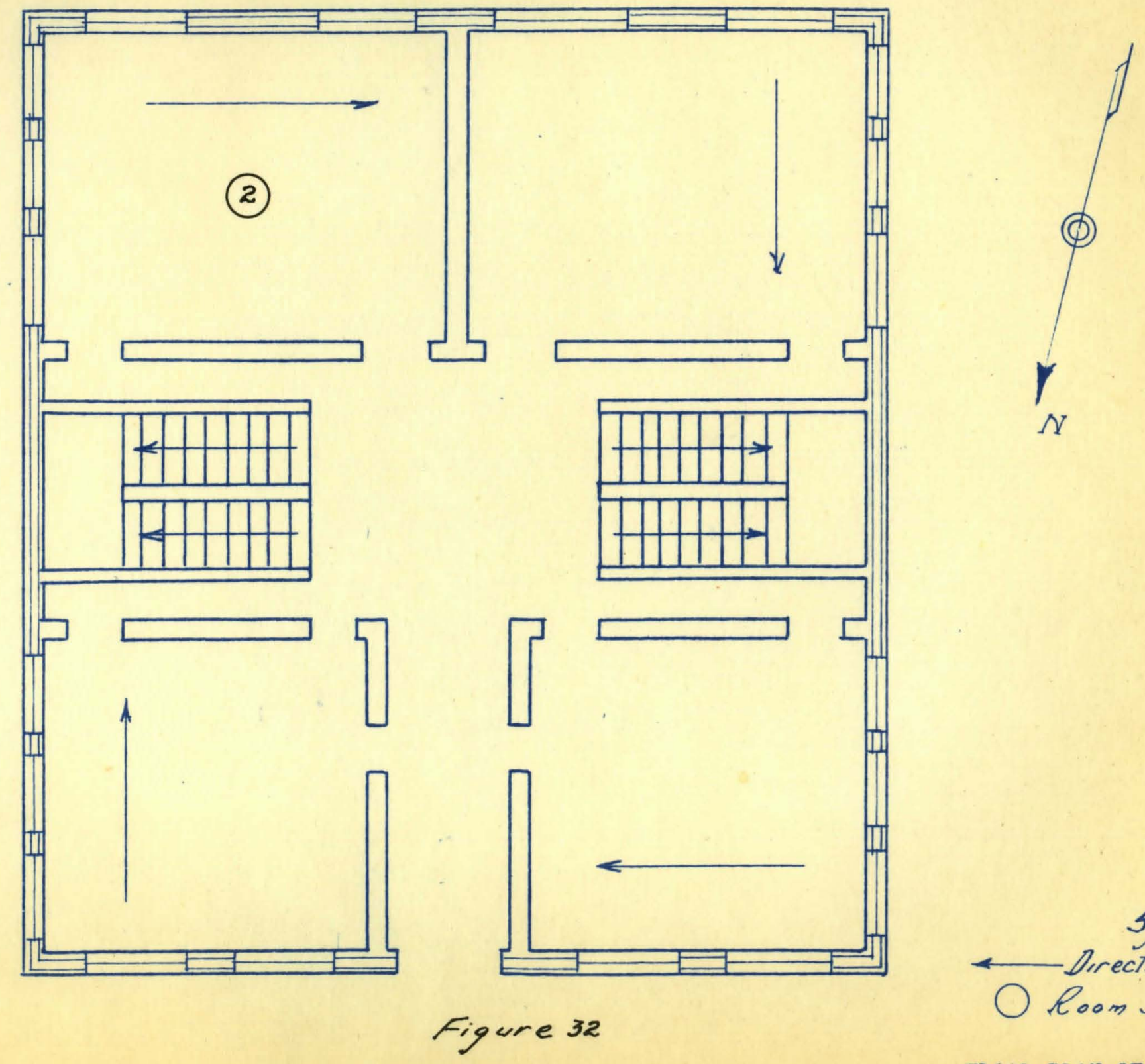

$\leftarrow \begin{gathered}\text { Symbols } \\ \text { Direction of Seating } \\ \text { Room Surveyed }\end{gathered}$ CHESTNUT STREET SCHOOL. 


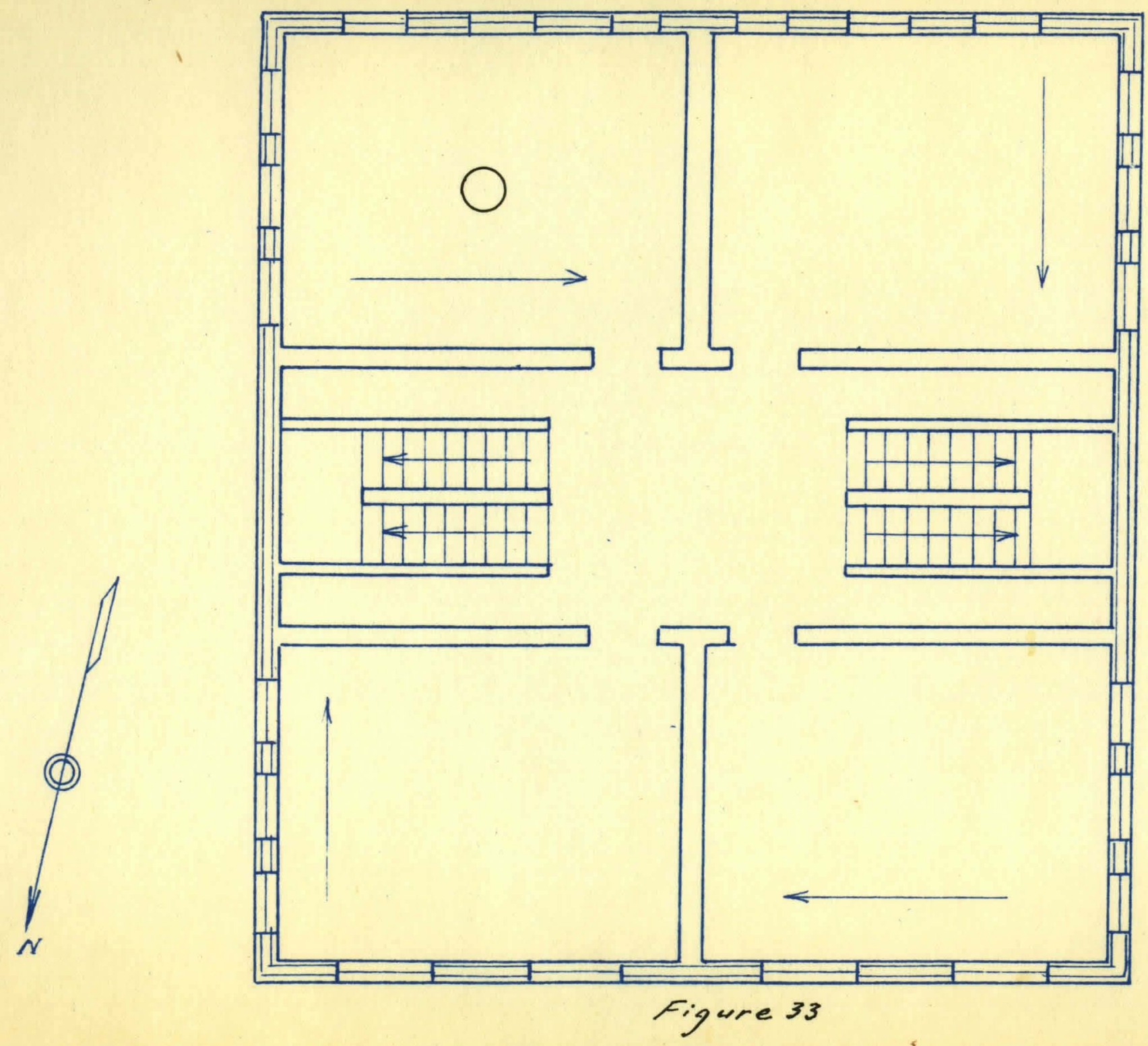

FLOCR PLAN CF SECOND FLCOR CHESTNUT STREET EIEM.SCHCOL. $\leftarrow$ Direction Symbols Seating $\bigcirc$ Room Surveyed. 


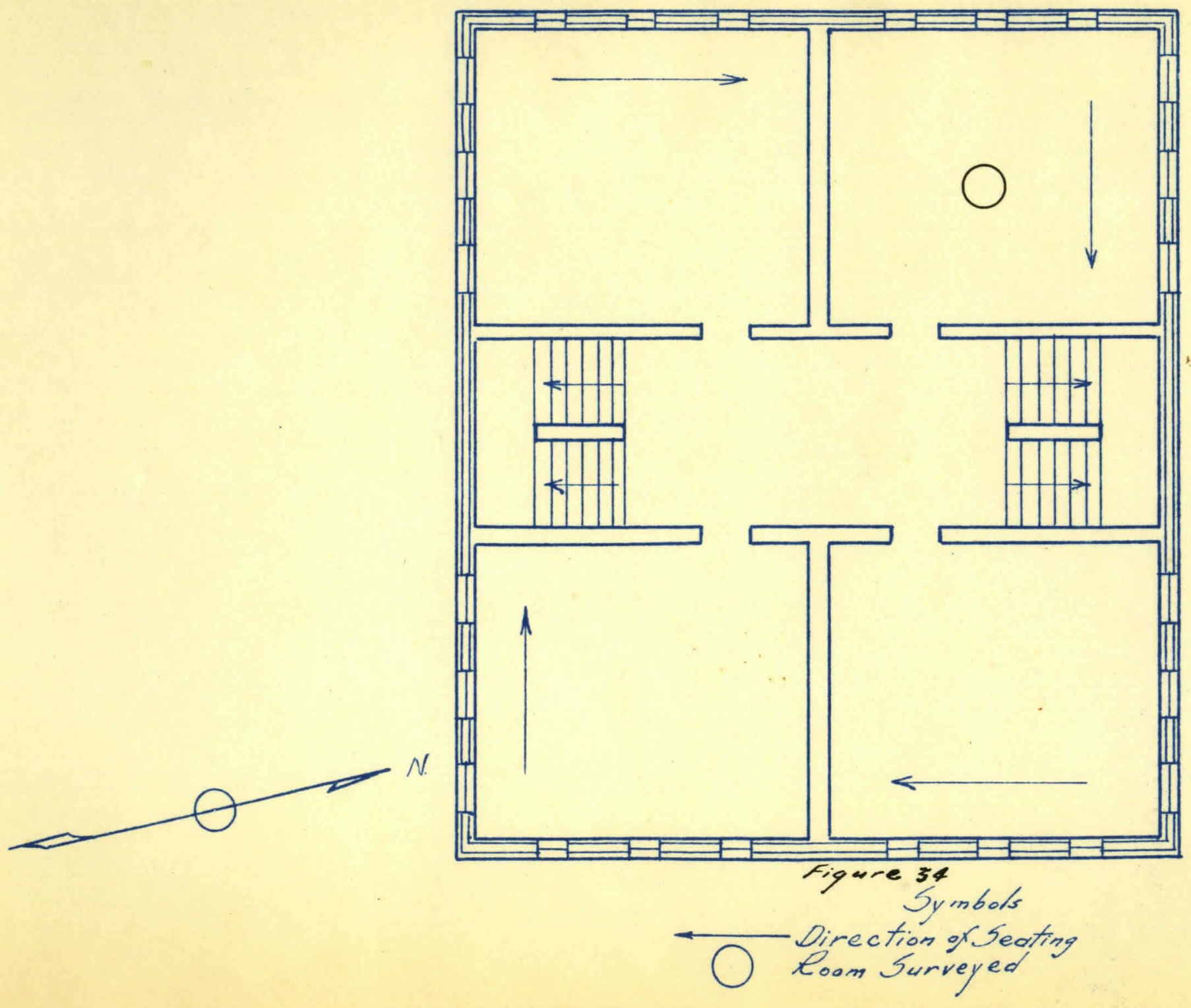

FLCOR PLAN OF FIRST FLOCR ROSE HILL ELEWENTARY SCHOOI 


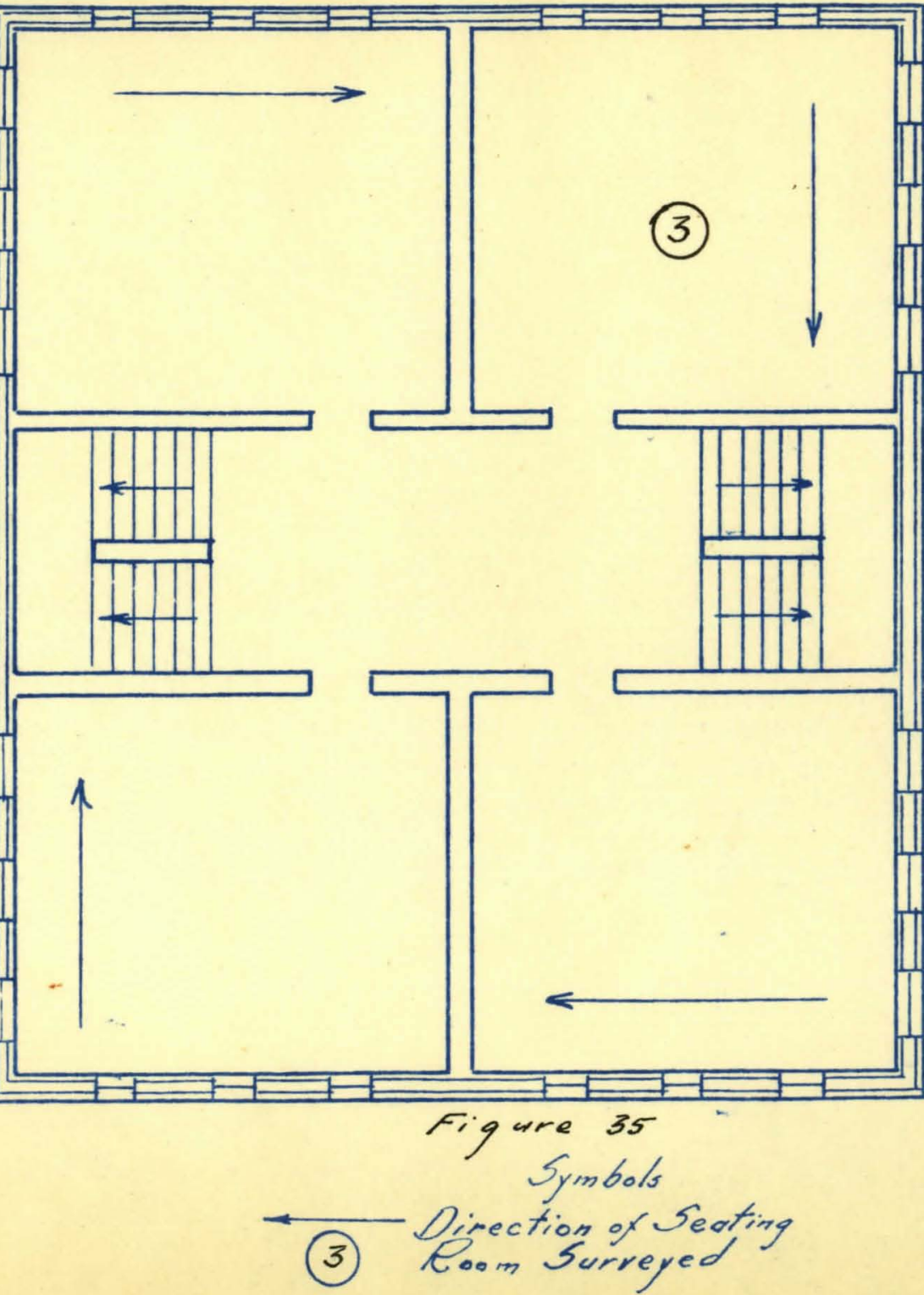

FLOOR PLAII OF SECOHD FLOOR BOSE HILL ELEMEETTARY SCHOOI 

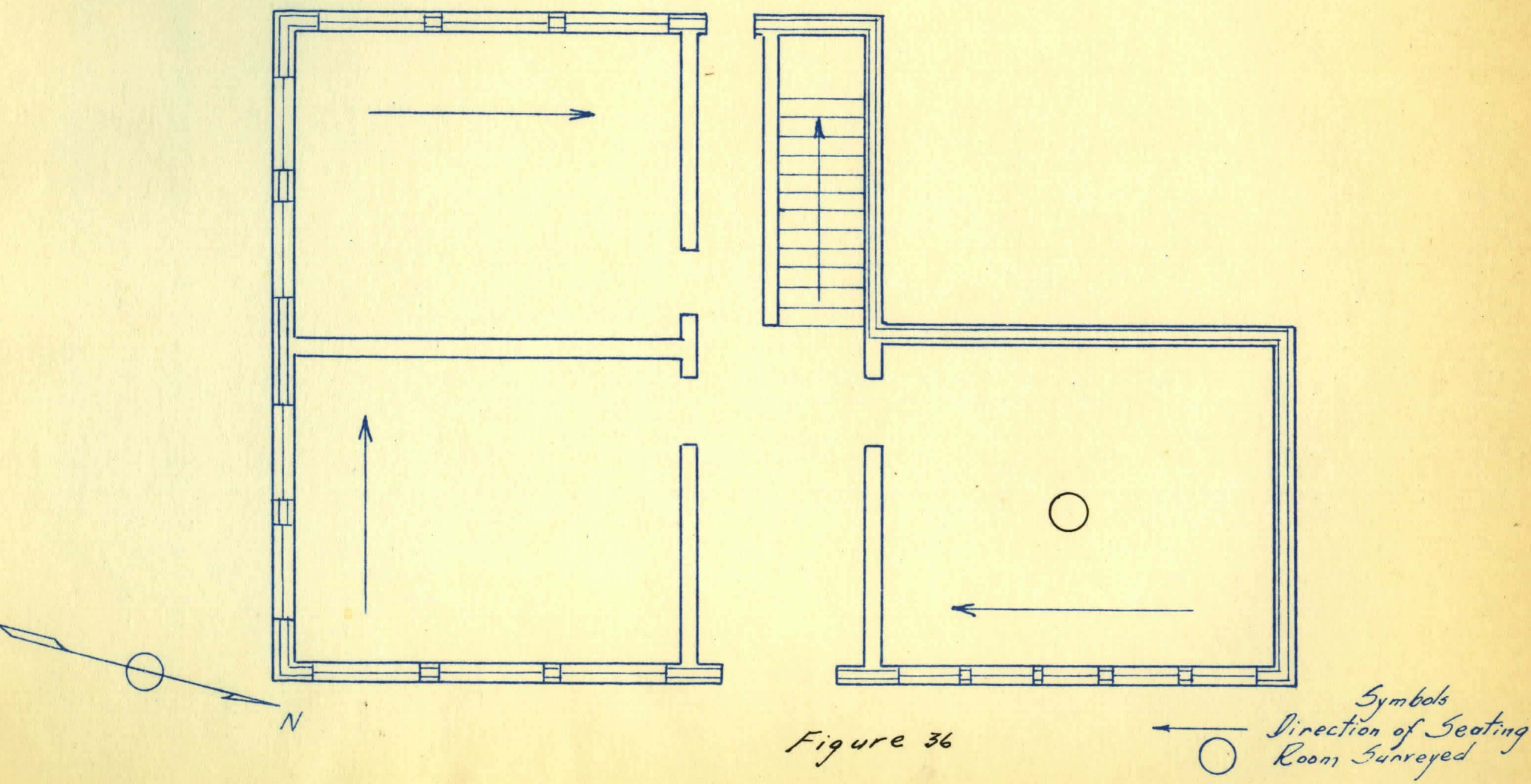

FLOOR PLAN OF FIRST FLOOR PORT PULTOW ELEMENTARY SCHOOL 

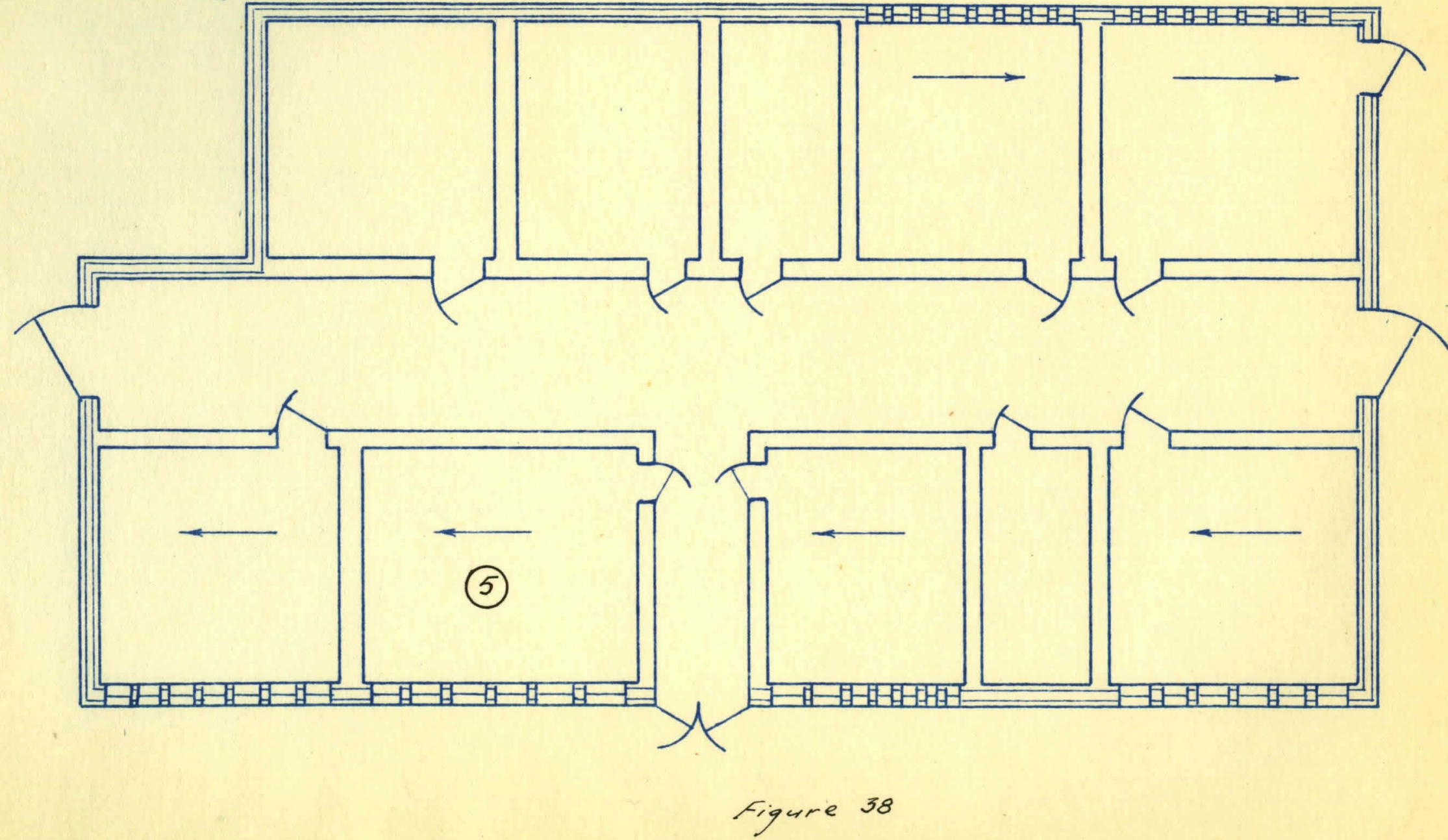

$$
\text { Symbols }
$$




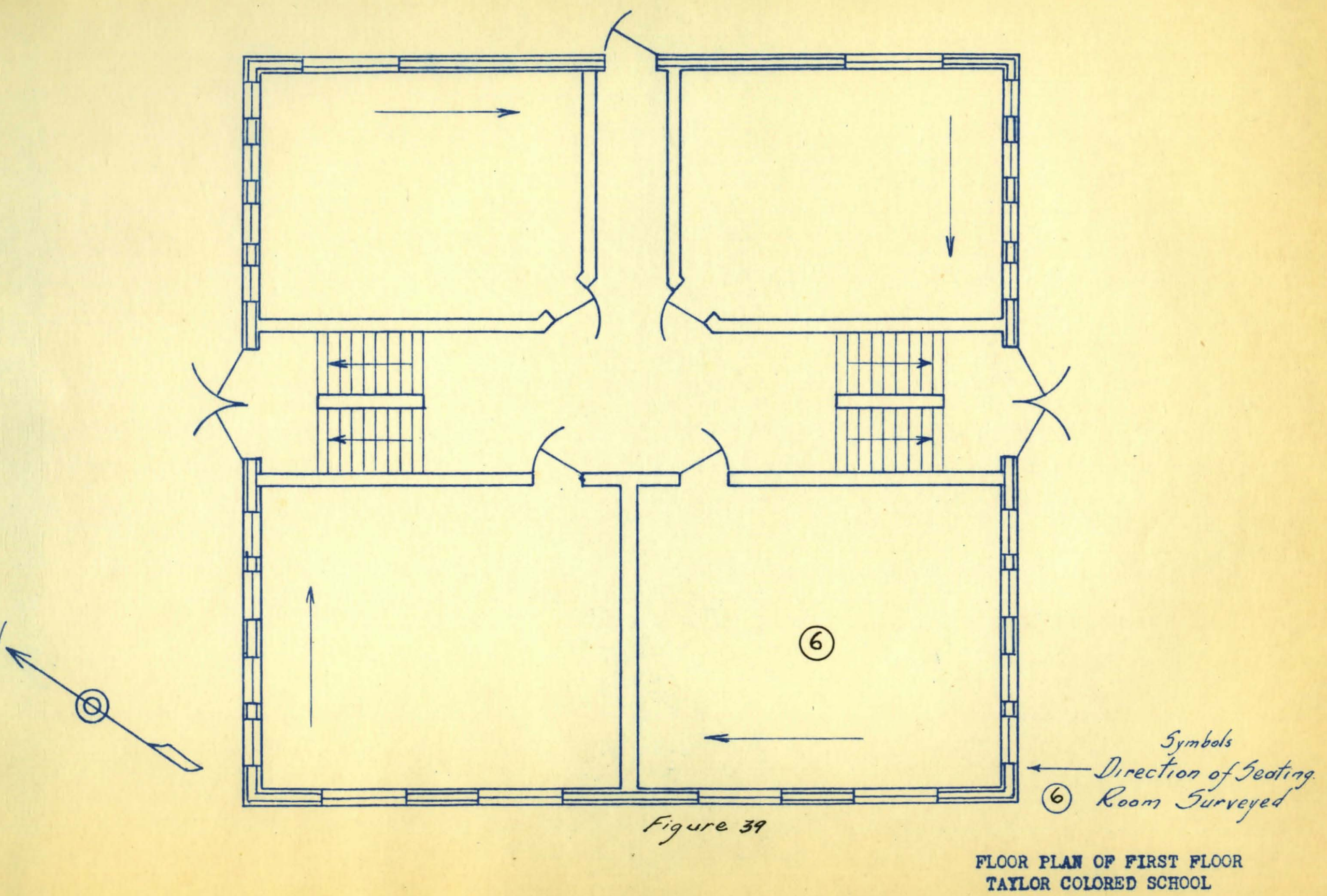

ثே TAYLOR COLORED SCHOOL 

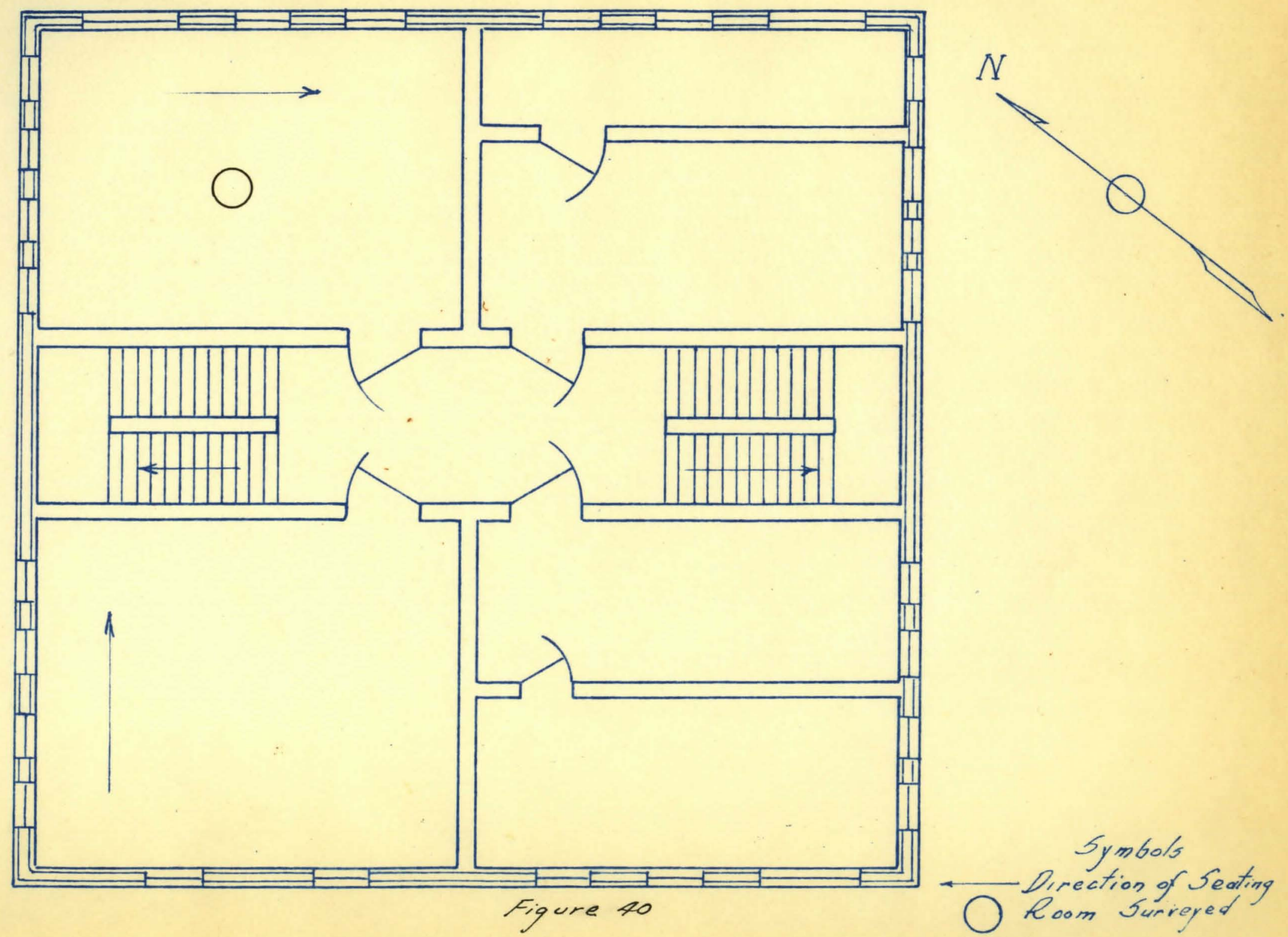

Symbols
Direction of Seating
Room Surreyed FLOOR PLAN OF SECOND FLOOR TAYLOR CCIORED SCHOOL 

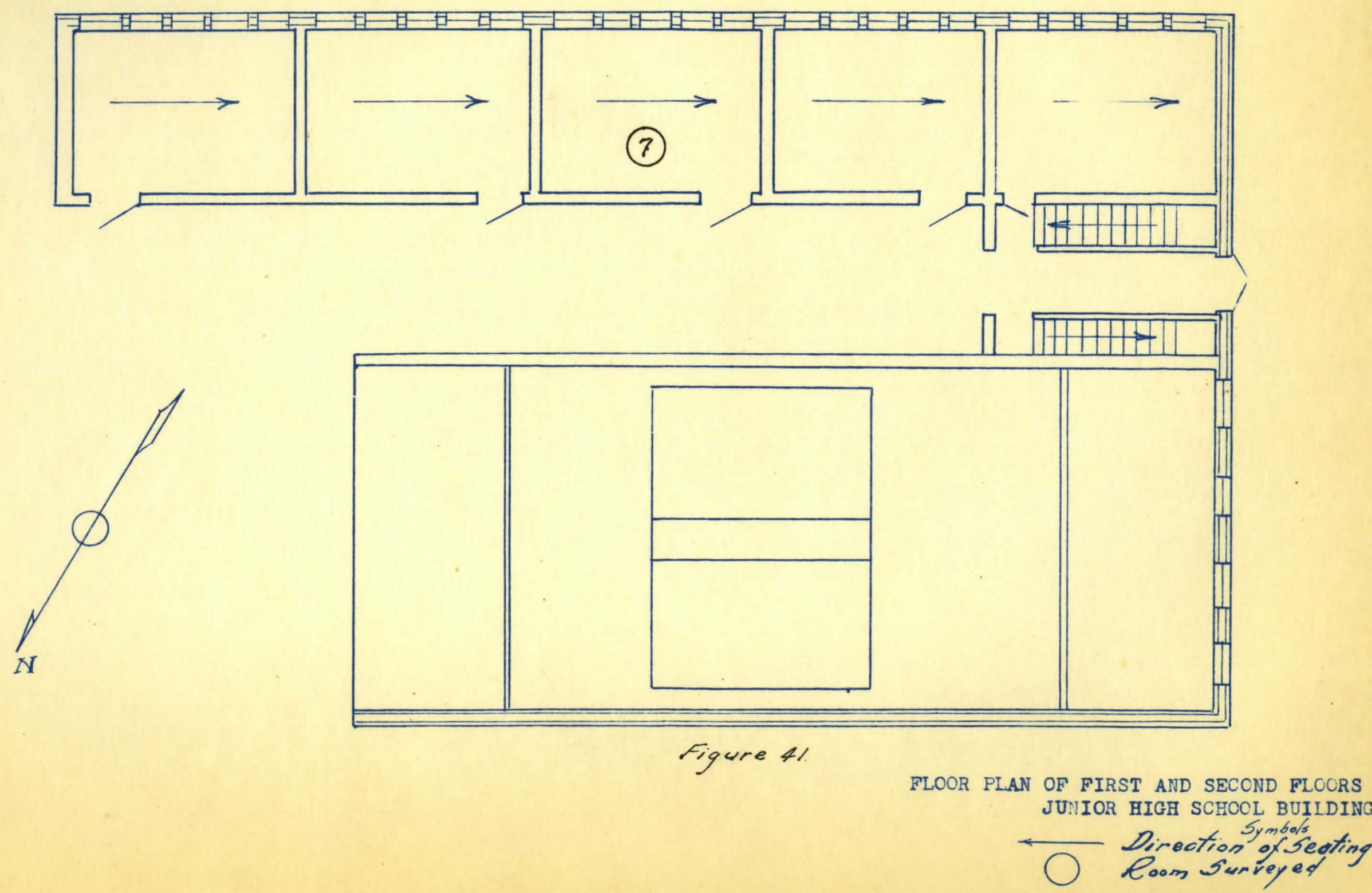


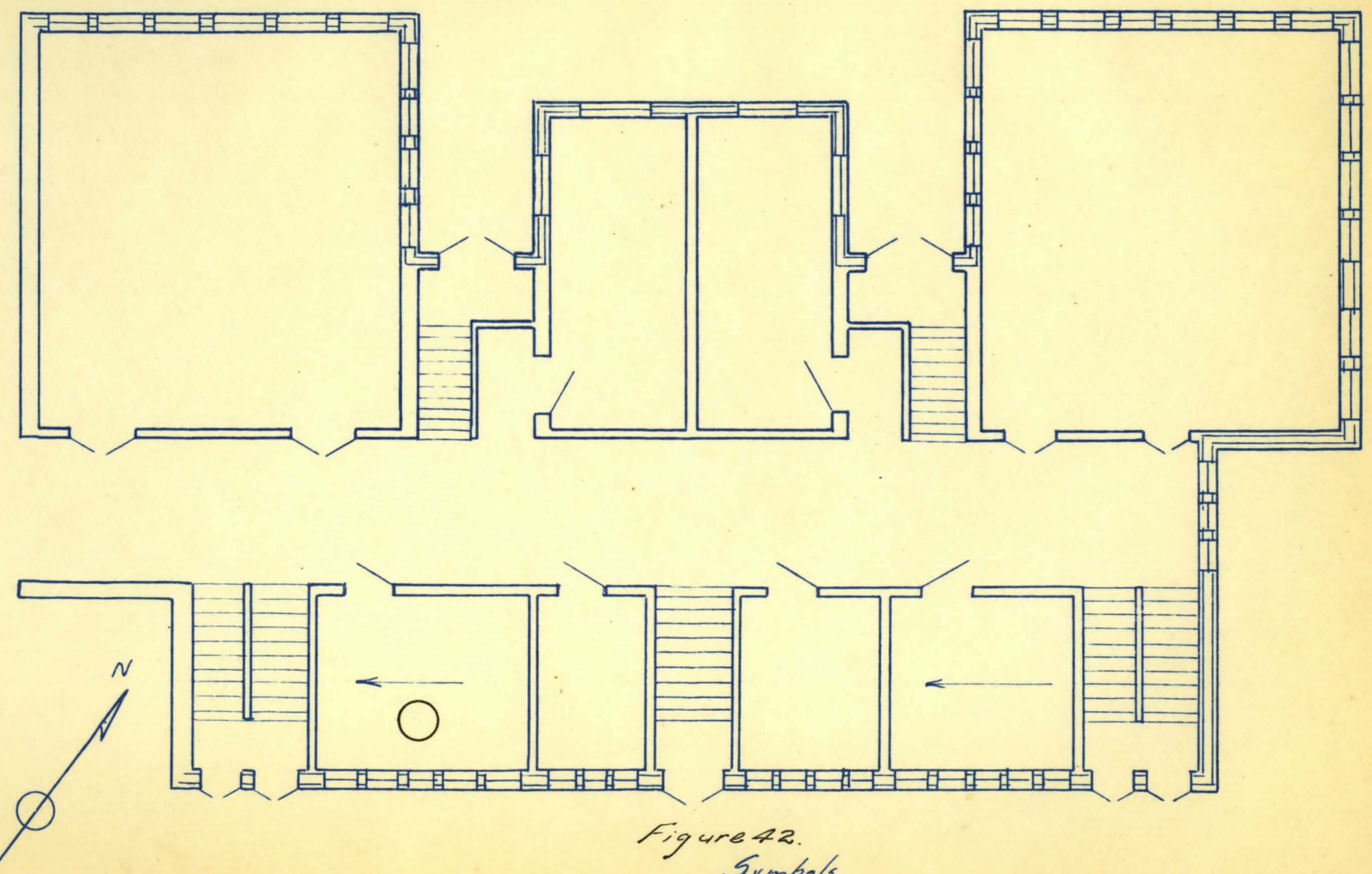

$+\begin{gathered}\text { Symbols } \\ \text { Direction of Seating }\end{gathered}$ 

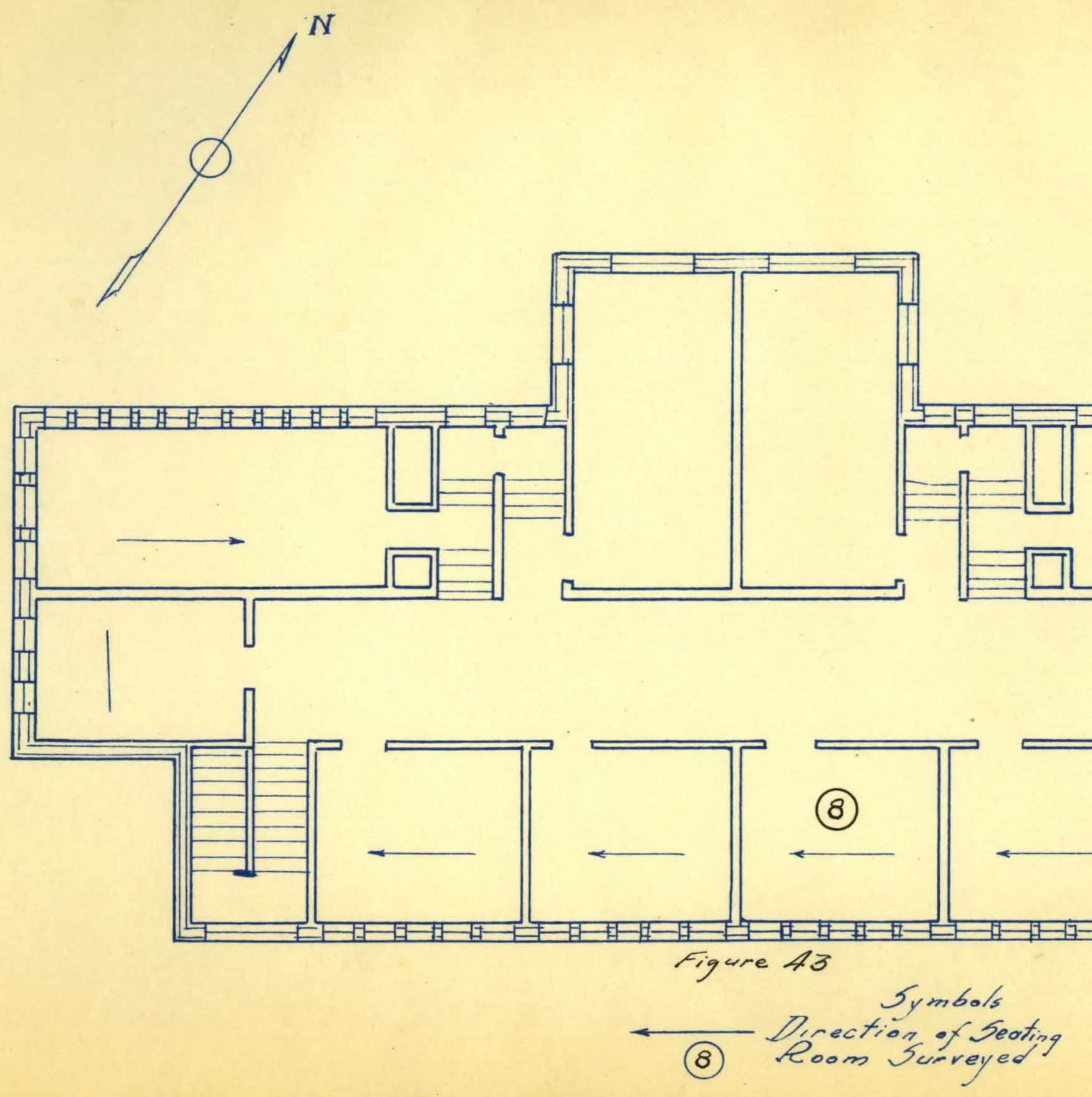

FLOOR PLAN OF SECOND FLOOR SENIOR HIGH SCHOOL BUILDING 


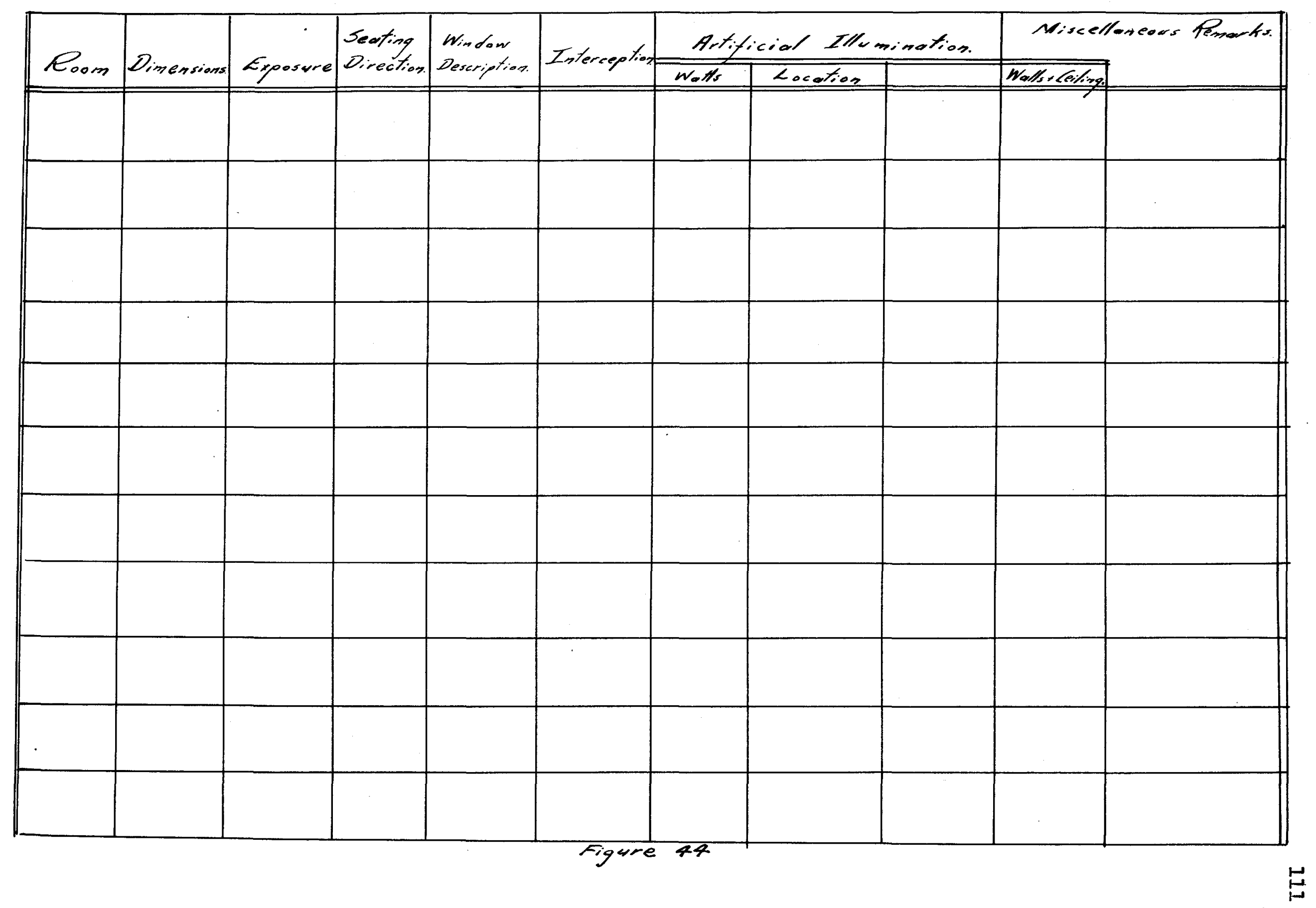




\section{Characteristic Curves of Typical Cells}

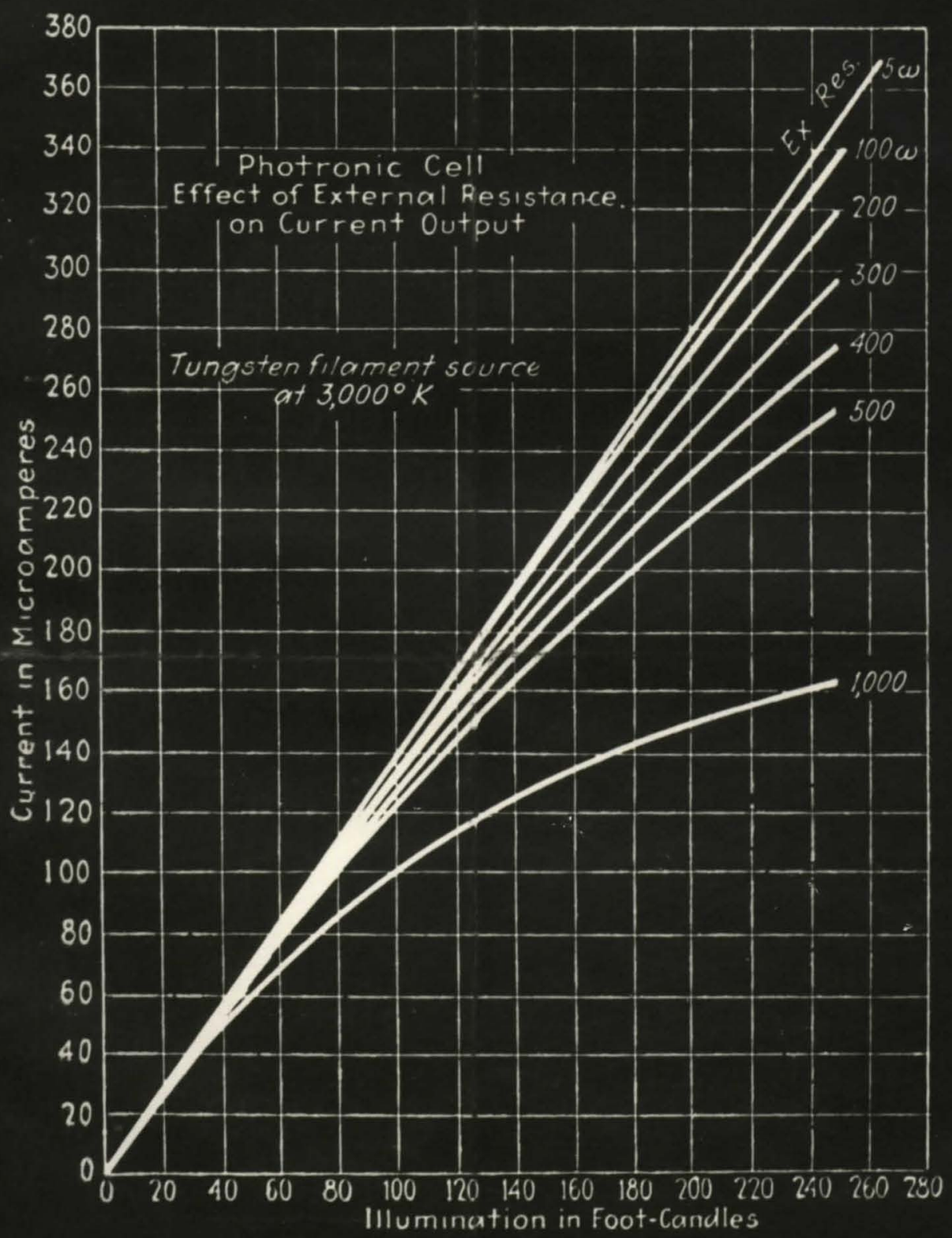

$$
\text { Figune } 45
$$

